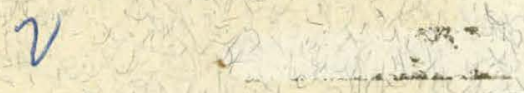

JPL PUBLICATION 82-12
DOE/ET-12548-11

Distribution Category UC-88

\title{
Health and Safety Evaluation of a Modified Tunnel-Borer Design for Application to Single-Entry Coal-Mine Development
}

Wayne F. Zimmerman

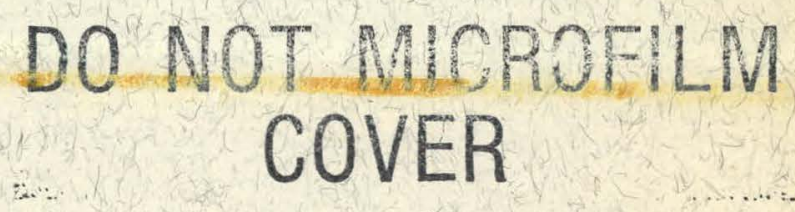

February 15,1982

Prepared for

U.S. Department of Energy

Through an Agreement with

National Aeronautics and Space Administration

by

* Jet Propulsion Laboratory

California Institute of Technology

Pasadena, California 


\section{DISCLAIMER}

This report was prepared as an account of work sponsored by an agency of the United States Government. Neither the United States Government nor any agency Thereof, nor any of their employees, makes any warranty, express or implied, or assumes any legal liability or responsibility for the accuracy, completeness, or usefulness of any information, apparatus, product, or process disclosed, or represents that its use would not infringe privately owned rights. Reference herein to any specific commercial product, process, or service by trade name, trademark, manufacturer, or otherwise does not necessarily constitute or imply its endorsement, recommendation, or favoring by the United States Government or any agency thereof. The views and opinions of authors expressed herein do not necessarily state or reflect those of the United States Government or any agency thereof. 


\section{DISCLAIMER}

Portions of this document may be illegible in electronic image products. Images are produced from the best available original document. 
DOE/ET/12548--11

DE82 013328

\section{Health and Safety Evaluation of a Modified Tunnel Borer Design for Application to Single-Entry Coal-Mine Development}

Wayne F. Zimmerman

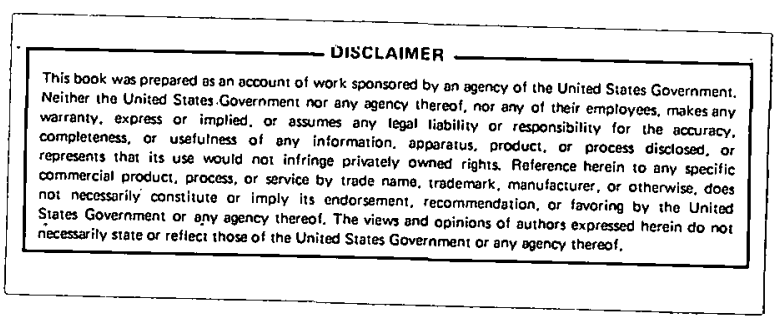

February 15, 1982

Prepared for

U.S. Department of Energy

Through an Agreement with

National Aeronautics and Space Administration

by

Jet Propulsion Laboratory

California Institute of Technology

Pasadena, California 
Prepared by the Jet Propulsion Laboratory, California Institute of Technology, for the U.S. Department of Energy through an agreement with the National Aeronautics and Space Administration.

This report was prepared as an account of work sponsored by an agency of the United Stares Government. Neither the United States Government nor any agency thereof, nor any of their employees, makes any warranty, express or implied, or assumes any legal liability or responsibility for the accuracy, com. pleteness, or usefulness of any information, apparatus, product, or process disclosed, or represents that its use would not infringe privately owned rights.

Reference herein to any specific commercial product, process, or service by trade name, trademark, manufacturer, or otherwise, does not necessarily constitute or imply its endorsement, recommendation, or favoring by the United States Government or any agency thereof. The views and opinions of authors expressed herein do not necessarily state or reflect those of the United States Government or any agency thereof. 
The health and safety analysis presented in this document is part of an overall effort to identify and develop innovative underground coal extraction systems. The single-entry tunnel borer system was initially considered an innovative approach to underground mining because it exhibited a means of increasing the speed and efficiency of entry development by reducing the number of entries. However, to be considered a truly advanced system, the tunnel borer had to meet distinct safety criteria as well. The objective was to examine the tunnel borer design and determine whether it offset major health hazards, and satisfied the prescribed safety levels. As a baseline for comparison, the tunnel borer was compared against the continuous mining entry driving system.

The results of the health analysis indicated that while the tunnel borer design offered improvements in dust control through the use of water sprays, a higher face ventilation rate, and the application of spalling rather than the conventional grinding process, it interjected an additional mutagen and toxic compound into the environment through the use of shotcrete.

The tunnel borer system easily conformed with the prescribed fatality limit, but exceeded the required limits for disabling and overall injuries. It also exhibited projected disabling and overall injury rates considerably higher than existing continuous mining injury rates. Consequently, the tunnel borer system was not considered an advanced system. 


\section{FOREWORD}

The JPL Advanced Coal Extraction Systems Definition Project is part of a program to develop advanced mineral extraction systems. This project focuses on five major areas:

(1) Planning and Management

(2). Systems Definition

(3) Concept Development

(4) Technology Assessment

(5). Systems Analysis

- This document, which provides the results of a health and safety analysis conducted on a single-entry tunnel boring concept, is the product of a subtask defined under the Systems Analysis area. The work was sponsored by the office of Mining, United States Department of Energy, through an interagency agreement, No. DE-AI01-76.ET12548, with the National Aeronautics and Space Administration (Task RD 152, Amendment 90). William B. Schmidt, Director of the. Office of Mining, is the project officer.

\section{ACKNOWLEDGMENT}

I would like to acknowledge the assistance provided by Lon Isenberg, Milt Lavin, and Jack Mondt who provided useful guidance in the organization of the document. I would also like to thank Maynard Serbousek, Bureau of Mines, Edward Hollett and Donald Hutchinson, Mine Safety and Health Administration; and Daniel Davidson, United Mine Workers, who participated in the safety analysis. 


\section{GLOSSARY}

\section{Definition of Symbols}

\footnotetext{
$B_{j} \quad$ The historical aggregate number of yearly body injuries for a given accident class $j$, associated with a conventional design used as a comparison against a protective feature of a new design.

$\mathrm{b}_{\mathrm{j}} \quad$ The aggregate projected yearly body injuries in a given accident class $j$, for a new design.

$\mathrm{d}_{\mathrm{j}} \quad$ The fractional adjustment in injuries of a given accident class $\mathrm{j}$, based on the consensus of a group of experts pertaining to a new protective device.

$f_{i} \quad$ The fractional change in the labor force for a given task $i$, between a new design and an analogous conventional comparison.

$g_{i} \quad$ The fractional adjustment in injuries for a given task $i$, based on the consensus of a group of experts pertaining to a new design.

$\mathrm{N}_{\mathrm{i}}$ The historical yearly injuries associated with a given task $i$, of an analogous conventional system used as a comparison against a new design.

$\mathrm{n}_{\mathrm{i}}$ The projected yearly injuries for a given task $i$, of a new design.

The time (hours) exposed to a given hazard for a task $i$, as performed in a new design.

$\mathrm{T}_{\mathrm{i}}$

The time (hours) exposed to a given hazard for a task $i$, as performed in a conventional system used as a comparison against a new design.
} 


\section{THIS PAGE}

\section{WAS INTENTIONALLY \\ LEFT BLANK}


I. INTRODUCTION AND SUMMARY . . . . . . . . . . . . . . . 1-1

A. OBJECTIVE ........................ 1-1

B. SUMMARY OF PREVIOUS STUDIES OF THE TUNNEL BORER SYSTEM $\cdot$. .1 - 1

C. SUMMARY OF THE EVALUATION APPROACHES AND RESULTS OF THE ANALYSIS . . . . . . . . . . . . . . . . . 1-3

D. STRUCTURE OF THE DOCUMENT . . . . . . . . . . . . . . . . 1-7

II. DESCRIPTION OF THE TUNNEL BORER AND CONTINUOUS MINER SYSTEMS . . . . . . . . . . . . . . . . . . . 2-1

A. OVERVIEW . . . . . . . . . . . . . . . . . . 2-1

B. DESCRIPTION OF SYSTEM COMPONENTS . . . . . . . . . . . . . 2-1

1. Tunnel Borer .................. 2-1

2. Continuous Miner ............... 2-2

C. SYSTEM OPERATION . . . . . . . . . . . . . . . . 2-4

1. Tunnel Borer .. . . . . . . . . . . . 2-4

2. Continuous Miner ............... 2-5

D. MANPOWER REQUIREMENTS . . . . . . . . . . . . . . . . 2-6

1. Tunnel Borer . . . . . . . . . . . . . 2-6

2. Continuous Miner ................ 2-7

3. Comparison of the Two Systems............ 2-7

III. HAZARD ANALYSIS ... . . . . . . . . . . . . . . . 3-1

A. OVERVIEW ........................ . . . . . . . .

B. TUNNEL BORER SYSTEM FAILURE ANALYSIS . . . . . . . . . . . . 3-1

1. Machinery Failures . . . ........... 3-2

2. Geological and Environmental Failures........ 3-4

3. Human Error . . . . . . . . . . . . . . 3-6 
C. HUMAN INTERACTION WITH SYSTEM FAILURES . . . . . . . . . 3-8

1. Machinery Failures . . . .......... . 3-8

2. Geological and Environmental Failures........ 3-9

3. Human Error ................... 3-10

D. HAZARD IDENTIFICATION . . . . . . . . . . . . . . . 3-11

1. Hazards Related to Machinery Failures
and Associated Human Errors........... 3-12

2. Hazards Related to Geologic and

Environmental Failures ............ 3-19

E. COMPARISON OF HAZARDS . . . . . . . . . . . . . . . 3-19

IV. QUALITATIVE HEALTH AND SAFETY EVALUATION . . . . . . . . . . 4-1

A. OVERVIEW . . . . . . . . . . . . . . . . . . 4-1

B. SELECTION OF AN ANALOGOUS SYSTEM . . . . . . . . . . . . 4-1

C. TEST OF REGULATORY CONFORMANCE . . . . . . . . . . . . . . 4-2

D. EVALUATION OF HEALTH AND SAFETY
IMPROVEMENTS . . . . . . . . . . . . . . . . . . . 4- 4

v. QUANTITATIVE SAFETY EVALUATION . . . . . . . . . . . . . . . 5-1

A. OVERVIEW ....................... 5-1

B. DATA INPUTS TO THE INJURY PROJECTION . . . . . . . . . . 5-2

1. Injury Data................. . 5-2

2. Task Time Data .. . . . . . . . . . . 5-2

3. Manpower Data . . . . . . . . . . . 5-3

4. Subjective Ratings of Protective
Measures ................. 5-7

C. INJURY PROJECTIONS . . . . . . . . . . . . . . . 5-12

1. Roof, Face, and Rib Fall Injuries......... . 5-14

2. Haulage Injuries. . . . . . . . . . . . . 5-14

3. Machinery Injuries................ 5-14 
4. Handling Material Injuries. . . . . . . . . 5-15

5. Explosion and Fire Injuries . . . . . . . . . 5-15

6. Electrical Injuries . . . . . . . . . . 5-16

7. Slip and Fall Injuries. . . . . . . . . . . 5-16

8. Hand-Tool Injuries ................ 5-17

9. Initial Injury Projection for Pressure

Release Hazards . . . . . . . . . . . . 5-19

D. INJURY ADJUSTMENT BY THE GROUP OF EXPERTS. . . . . . . . . . . . . 5-19

1. Roof, Face, and Rib fall Injuries.......... . 5-22

2. Haulage Injuries. . . . . . . . . . . 5-23

3. Machinery Injuries. . . . . . . . . . . 5-25

4. Handling Material Injuries............. . 5-25

5. Explosion and Fire Injuries .......... . 5-25

6. Electrical Injuries .............. . . 5-27

7. Slip and Fall Injuries .... . . . . . . . . 5-27

8. Handtool Injuries . . . . . . . . . . . 5-29

9. Pressure Release Injuries .......... . . 5-29

VI. CONCLUSIONS . . . . . . . . . . . . . . . . 6-1

A. NVERVLEW . . . . . . . . . . . ...... . 6-1

B. COMPARISON OF INJURY RATES ................. 6-1

1. Continuous Miner Injury Rate

Comparison . . . . . . . . . . . . . . 6-1

2. Safety Requirement Injury Rate

Comparison . . . . . . . . . . . . . . 6-3

C. SUGGESTED AREAS FOR DESIGN IMPROVEMENT . . . . . . . . . 6-3

VII. REFERENCES ............................ . . . . . 1 
APPENDIXES

A. DETAILED INJURY PROJECTIONS BY ACCIDENT

CLASS AND HAZARD . . . . . . . . . . . . . . . . . A-1

B. DETAILED INJURY ADJUSTMENTS BY GROUP OF EXPERTS,

BY ACCIDENT CLASS AND HAZARD . . . . . . . . . . . . B B-1

\section{Figures}

2-1. Layout of Tunnel Borer Entry Development System . . . . . 2-3

$\underline{\text { Tables }}$

1-1. Results of the Tunnel Borer Health Analysis........ . 1-5

1-2. Annual Injury Rate Comparison for the Continuous

2-1. Manpower Required by the Tunnel Borer . . . . . . . . 2-7

2-2. Manpower Required by the Continuous Miner . . . . . . . 2-8

3-1. Relative Frequency of Major Machinery-Related Failures . . 3-5

3-2. Relative Frequency of Geological and Environmental

Failures ..................... 3-7

5-1. Exposure Time Comparison between the Tunnel

Borer and Continuous Miner Systems. . . . . . . . . . 5-4

5-2. Detailed Manpower Comparison between the

5-3. Ratings for Tunnel Borer Protective Measures . . . . . . 5-9

5-4. Initial Injury Projection for Roof,

5-5. Haulage Injury Projection . . . . . . . . . . . . 5-16

5-6. Initial Injury Projection for Machinery Hazards . . . . . 5-17

5-7. Initial Injury Projection for Handling
Material Hazards............... 5-18

5-8. Initial Injury Projection for Explosion

and Fire Hazards . . . . . . . . . . . . 5-18

5-9. Initial Injury Projection for Electrical
Hazards ............... . . . . . . . . . . . 
5-10. Initial Injury Projection for slip and

Fall Hazards................... . 5-20

5-11. Initial Injury Projection for Hand-Tool Hazards . . . . . 5-21

5-12. Initial Injury Projection for Pressure

Release Hazards . . . . . . . . . . . . . 5-22

5-13. Final Projections for Roof, Face,

and Rib Fall Injuries .. . . . . . . . . . 5-23

5-14. Final Projections for Haulage Injuries . . . . . . . . 5-24

5-15. Final Projections for Machinery Injuries . . . . . . . 5-26

5-16. Final Projections for Handling Material

Injuries... . . . . . . . . . . . . . . 5-26

5-17. Final Projections for Explosion and

Fire Injuries . . . . . . . . . . . . . 5-27

5-18. Final Projections for Electrical Injuries . . . . . . . 5-28

5-19. Final Projections for S1ip and Fall Injuiries . . . . . 5-28

5-20. Final Projections for Hand-tool Injuries . . . . . . . 5-30

5-21. Final Projections for Pressure Release

Injuries. . . . . . . . . . . . . . . 5-30

6-1. Detailed Injury Rate Comparison for the Continuous Miner and Tunnel Borer Systems, by Accident Class . . . . . 6-2

6-2. Comparison of Injury Rates for the Tunnel

Borer System with the Safety Requirements . . . . . . 6-3 
SECTION I

INTRODUCTION AND SUTMMARY

\section{A. OBJECTIVE}

The Jet Propulsion Laboratory's Advanced Coal Extraction Systems Definition Project, sponsored by the U.S. Department of Energy (DOE), Office of Mining, was established to define and develop innovative underground coal extraction systems suitable for the significant resources remaining in the year 2000. The development of a single-entry tunnel boring system appears to have attractive ground control characteristics in comparison to conventional room and pillar roof support systems, and also exhibits a means of increasing the speed and efficiency of entry development by reducing the number of entries. These attributes make the tunnel borer a prime candidate as an advanced system. In addition to these assets, a new system such as the tunnel borer must also demonstrate a potential to reduce miner disabling injuries and fatalities to levels comparable to other heavy industries which have similar hazards. Similar industries such as construction, primary metal manufacturing, metal and non-metal mining, and petroleum extraction exhibit trends toward 0.2 fatalities per million manhours, 30 disabling injuries per million manhours, and 40 to 45 overall injuries per million manhours. These injury levels represent the safety requirement for new designs under the guidelines established by the Advanced Coal Extraction Project. This requirement represents approximately a 50\% reduction in existing underground coal mining injury rates ( 1 ).

The objectives of this study are to examine the health and safety assets of the tunnel borer system in comparison to contemporary continuous mining room and pillar operations, determine both design strengths and weaknesses, and establish whether the tunnel borer can satisfy the stated safety requirement.

To meet the objectives, the study drew on past tunnel borer engineering and safety studies, and health and safety evaluations designed as part of the Advanced Coal Extraction Project (2). The following sections summarize the findings of the previous studies, and the evaluation schemes employed in this analysis. The key results of the health and safety evaluations are also provided as an overview. Finally, a brief paragraph stating the general structure of the document is provided as a guide to the overall design of the analysis.

\section{B. SUMMARY OF PREVIOUS STUDIES OF THE TUNNEL BORER SYSTEM}

The demonstration and evaluation of the tunnel boring machine in underground coal mining was a research and development project sponsored by the U.S. Bureau of Mines, as part of their High Speed Coal Mine Development Systems Program. In support of this project the Bureau of Mines sponsored a system feasibility and safety impact study by James A. Cobb Engineering, Tulsa, Oklahoma; and DOE sponsored a safety assessment by Battelle Pacific Northwest Laboratories. Although the basic thrusts of the studies were different, the conclusions were very similar. The cobb study concentrated on 
the engineering aspects of designing a safe single-entry system; whereas the Battelle study was directed more towards a comparative assessment of the tunnel borer with existing hardware and hazards $(3,4)$. . The Cobb study was performed at about the same time the Bureau of Mines approved and funded the tunnel borer project, and was responsible for much of the design of the system. The Battelle study was completed after the prototype system was in operation and essentially drew on an already firm design.

In examining the problem of designing a single-entry system, the Cobb analysis first looked at the tunneling industry. The initial clue to the possibility that tunneling was safer than contemporary coal mining entry driving systems came from an overall comparison of injury rates between the tunneling industry and the underground mining industry. That comparison suggested that fatality and disabling injury rates in tunneling were approximately half that of underground coal mining (3). In studying the single-entry tunneling concept further, stress calculations indicated that under the same geologic conditions, a circular entry was more stable than the normal rectangular. entry used in coal mining. Additional calculations on airflow through tubes versus rectangular ducts suggested that a circular entry also had a better geometry for allowing more ventilation air to reach the face and dilute liberated methane. Recognizing ground control and methane release problems as major sources of hazards in underground mining, the Cobb analysis suggested additional hazard control measures. In the ground control area, the Cobb study recommended bolting the roof, followed by spraying a layer of shotcrete over the tunnel walls. Stress calculations indicated that shotcrete demonstrated considerable load supporting characteristics down to a thickness of 2 in. As an additional control over methane liberation, it was recommended that the seam be degasified in advance of the boring machine through the use of an inseam degasification drill. Although degasification of coal seams is not new, it was felt that inseam degasification would provide a means of liberating a greater amount of the trapped methane. The net thrust of the Cobb study suggested that the tunnel borer single-entry system would be inherently safer than contemporary room and pillar entry driving systems through improved ground control measures, better ventilation, and inseam degasification (3).

The subsequent Battelle study examined the hazards of the tunnel borer system in greater detail (4). Determining the potential of the tunnel borer to reduce fatalities in the major accident categories of roof/face falls, haulage, explosion/fire, machinery, and electrical was the prime focus of this safety analysis. The first phase of the analysis was to understand the mechanisms of worker fatalities in conventional coal mining through fatality statistics, and the conditions or components of the system that contributed to deaths. This phase helped establish the safety similarities and differences between the two systems, and identified the historically hazardous conditions which would become obvious by their absence or presence in the tunnel borer system. The Battelle analysis then comprehensively compared the two systems in all of the above accident classes. The last step in the analysis was to apply a subjective rating to the assets and liabilities of the tunnel borer system in terms of the potential impact on reducing fatalities. The results of the Battelle study encompassed more accident classes than the Cobb evaluation (4). The Battelle evaluation agreed with the results of the Cobb analysis pertaining to the effect that improved ground control measures, better ventilation, and degasification would have on reducing serious injuries 
because of rock falls and explosion. Additionally, the straight line layout of the machinery components of the tunnel borer system was projected to have a considerable impact on reducing fatalities caused by machinery impact. Finally, the attachment of the main power cable to the rib, away from the working areas, was projected to have a sizable impact on reducing fatalities related to electrical shock.

Both the Cobb and Battelle studies were performed at a very general level. For example, both examined the safety characteristics of the tunnel borer from the standpoint of reducing worker exposure to roof falls. This level of analysis has value in identifying basic strong points of a new design. However, workers are exposed to different kinds of accidents in a variety of ways during the performance of various tasks. Furthermore, some tasks are more hazardous than others. One of the overall objectives of the Advanced Coal Extraction Project is to identify innovative mining systems. Several of these systems could demonstrate general safety improvements in any given accident class and only one may offset the serious hazards. The actual benefits of each system would not become clear unless a more detailed hazard analysis was conducted. This level of analysis requires a deeper examination of all the variables that affect injury frequency and severity. The health and safety evaluations developed under the Advanced Coal Extraction Project, and applied in this document, provide a means to examine new designs in greater depth. Since the tunnel borer system exhibited advanced design characteristics, it provided an excellent test case for the application of the evaluations. Much of the engineering data provided in the previous studies were applicable to the detailed hazard and design analyses performed in this report.

\section{SUMMARY OF THE EVALUATION APPROACHES AND RESULTS OF THE ANALYSIS}

The evaluations used in this report apply to new designs as they move from a conceptual level to a more firm preliminary design. The conceptual level evaluation is qualitative in nature and serves only to establish whether a new design offers health and safety improvements over contemporary systems. The preliminary design level evaluation is quantitative and projects the possible effects the new concept could have on reducing injuries. Since the tunnel borer was completed through the prototype stage, the terms "conceptual" and "preliminary" design do not apply. For the purpose of this study, the conceptual and preliminary design evaluations will be respectively termed "qualitative" and quantitative" evaluations.

The health and safety evaluations applied in this study are similarly structured. Both analyses comence with a complete analysis of potentially hazardous system failures, followed by an examination of the human interfaces with hazardous system and geological failures. These two elements are essential to evaluating new designs to ensure that existing, and possibly new, hazards are identified. Since advanced systems may not resemble existing hardware at all, new hazards cannot be assessed until the detailed failure modes, peculiar to the new system, are understood. The complete analysis of these two elements comprises the actual hazard analysis and delineates the potential hazards. 
The next step is to compare the new system against a similar existing system to identify health and safety improvements. This is done at a qualitative level to: (1) determine if a new design offers sufficient merit over existing systems to warrant further development, and (2) direct the evaluator toward both strong and weak areas of the design that should be evaluated more closely later on. The important qualitative measures for safety improvements are: (1) reduced exposure time by improved equipment design and/or streamlined operations, and (2) more worker protection. The health evaluation of new designs ends at this stage because actual levels of exposure to dust, toxic materials, or vibration can only be determined when a prototype is developed and operated. However, the safety methodology continues into a quantitative stage where an injury projection is made. The data required for the injury projection includes task time and crew size comparisons, additional protective devices, and machinery redesign possibilities. For each task, manhours at risk are multiplied by the injury rates observed for similar equipment, and then total system safety performance is estimated by aggregating rates for various tasks and hazards. This projection of injuries per million manhours of exposure represents a logically structured estimate of whether the new system can meet the target safety requirement. Expert judgment is included to adjust these projections for potential nonlinear relationships between the degree of exposure to hazards and the resultant injuries.

The conventional equipment used for comparison against the tunnel borer was the continuous miner room and pillar system. The comparison was based on both systems being used to drive entries in preparation for longwall extraction. Since the continuous miner is not similar to the tunnel borer in its operation or architecture, the two systems were compared with the intention of replacing the continuous miner system with the tunnel borer since the tunnel borer appeared inherently safer.

The results of the qualitative design evaluation suggested that the tunnel borer entry driving system had several safety advantages over the present continuous miner system in the areas of roof/face falls, haulage, machinery, and explosions. The major advantage appeared to be in ground control. This advantage stemmed from a circular roof contour (providing a better distribution of geologic stresses), and the joint use of roof bolts and shotcrete ( 3 ). Additionally, the flexicore panels, skid, and heavy-duty canopy for the roof bolters enhanced the protection provided by the system against roof falls. The results also indicated that haulage accidents near the face could be reduced by use of an overhead conveyor instead of placing the conveyor on the floor of the entry. This design appeared to reduce exposure to being struck or caught by the moving conveyor. Continuous miners, roof bolters, and haulage equipment operating in the presence of other machinery, are major sources of machinery related injuries. Conceptually it appeared that the slower moving tunnel borer (constrained to move in one direction), integrated miner-roof bolters, and the removal of manned haulage would help reduce machinery in the face area, and subsequent injuries. The tunnel borer degasification system, in conjunction with automatic gas monitoring, a greatly reduced cutter head speed, and improved ventilation, appeared to be positive design elements to control explosions and fire.

The results of the health analysis were also completed at the end of the qualitative evaluation and are summarized in Table 1-l. 
Table 1-1. Results of the Tunnel Borer Health Analysis (Conventional Continuous Miner used as a Comparison)

Design Improvement

Positive Neutral Negative

Health Hazards

Dust

$\mathrm{X}$

Toxic compounds

Temperature/Humidity

Noise

Vibration

Poor Lighting

Psychological stress caused

by cramped work space

Negative

The indicated improvement in dust control was based on an extension of the design beyond dust suppression techniques presently in use. Existing techniques include water sprays and ventilation. The tunnel borer employs these features as well as a lower speed cutter head which fractures the coal by spalling. This technique results in a larger particle size, which, in-turn, reduces the amount of airborne dust.

Table 1-1 shows negative improvement in the release of toxic elements into the mine environment. Detailed examination of the tunnel borer indicated that this health hazard would be aggravated by the use of shotcrete, which is basically cement mixed with an epoxy accelerator. Both the cement and epoxy represented health hazards because of the possibility of inhalation and skin contact during the shotcrete spraying process. The tunnel borer design offered no improvements beyond existing conditions in the areas of temperature and humidity controls, noise, and equipment vibration. However, the tunnel borer did offer some design improvements in providing workers substantially improved lighting, and less cramped work space (i.e., a constant ten feet clearance between the floor and the tunnel divider).

The injury projection is the last stage of the evaluation and is summarized in Table 1-2, which presents the average yearly injury rates for both the continuous miner and tunnel borer systems for the dominant accident classes. The continuous miner injury data are based on a 4-yr average of Mining Safety and Health Administration (MSHA) injury statistics (5). Of the major accident classes 1 isted in Table 1-2, the tunnel borer demonstrated the greatest improvement in reducing roof and face fall injuries, resulting from the extensive ground control system. The improvement in haulage injuries was caused by placing the conveyor overhead and away from the workspace areas, and by eliminating shuttle cars and loaders. The slight projected decrease in electrical injuries primarily was due to removing the trolley wire from the system, reducing the number of electrical cables and amount of cable handing, and placing the main power cable in a relatively inaccessible position on the rib. 
Table 1-2. Annual Injury Rate Comparison for the Continuous Miner (CM) and Tunnel Borer (TB) Systems, by Accident Class (injuries per million manhours)

\begin{tabular}{lllll} 
& \multicolumn{2}{c}{ Fatalities } & & \multicolumn{2}{c}{ Disabling Injuries } \\
\cline { 2 - 3 } Accident Class & CM & TB & & TB \\
\hline Roof/face/rib falls & 0.14 & 0.01 & 3 & 3 \\
Haulage & 0.06 & 0.03 & 4 & 23 \\
Machinery & 0.03 & 0.01 & 5 & 29 \\
Handling Material & 0 & 0 & 11 & 0.03 \\
Explosion/fire & 0.03 & 0.03 & 0.03 & 0.6 \\
Electrical & 0.02 & 0.02 & 1 & 7 \\
Slip/fall & 0 & 0 & 4 & 6 \\
Handtools & 0 & 0 & 2 & 77 \\
Pressure line bursts & 0 & 0 & 0 & 70 \\
Total & 0.3 & 0.1 & 30 \\
\hline
\end{tabular}

The major design weaknesses stemed from machinery and handling material hazards. Although the tunnel borer demonstrated some additional protective aspects such as remote miner operation, an integrated miner-roof bolter system, and elimination of vehicular haulage, the introduction of additional equipment offset these advantages. Equipment such as cranes, shotcrete machines, and large rib drills are used in the tunneling industry and have tabulated injury rates. The use of this standard equipment for ground control, flexicore and beam installation, and degasification resulted in a projected increase in disabling injuries. The injury projection for handling material was aggravated by the large manhours and workforce required to install the tunnel divider. Similarly, hand-tool injuries were also projected to increase because of the greater usage of hand tools during beam, pipe, and flexicore installation. The projected increase in disabling injuries resulting from bursting pressure lines or fittings was due to the large amount of hydraulic and pneumatic machinery associated with the tunnel borer system. Though the explosion-related injuries were somewhat mitigated by the degasification and automatic shutdown systems, these were offset by a slight projected increase in fire-related injuries because of the use of flamable hydraulic fluid, and the poor placement of the gas monitor in relation to the face (i.e., small pockets of gas undetected by the gas monitor could ignite residual hydraulic fluid).

Overall, the tunnel borer demonstrated a sizable reduction in the fatality rate, well below the target fatality requirement of no more than 0.2 fatalities per million manhours. However, the projected disabling and total injury rates of 77 and 100 injuries per million manhours, respectively, fell short of both the safety performance of present continuous mining systems and the safety requirement for advanced systems. In conclusion, it appears that the tunnel borer would not be considered an advanced design from the standpoint of safety. 


\section{STRUCTURE OF THE DOCUMENT}

This document is designed so the reader is first introduced to both the continuous miner and tunnel borer systems. Section II provides this introduction through a detailed discussion of system architectures, operations, and workforce. This information is then used in Section III to develop the hazard analysis. Section IV provides the framework and results of the qualitative health and safety analyses. The results of these analyses form the foundation for the in-depth injury projections made in section $v$, the quantitative design evaluation. This section explains all the factors used in making the projections and provides injury projections for the major hazards identfied with the tunnel borer. Section $V$ also sumarizes the adjustment of the injury projections based on the results of the interviews with the experts. The final statements on the health and safety performance of tunnel borer in relation to the safety requirements are provided in Section VI. Concluding comments pertaining to suggested design improvements are also included in this section. Supporting data for the analysis are provided in the Appendix. 
SECTION II

DESCRIPTION OF THE TUNNEL BORER AND CONTINUOUS MINER SYSTEMS

\section{A. OVERVIEW}

Both the tunnel borer and continuous miner are basically entry driving systems. These extraction systems lay out large tracts of coal in preparation for longwall retreat, or advance, mining. The major difference between the tunnel borer and continuous miner is the entry development process. The tunnel borer drives one continuous entry through a tract of coal in such a way as to outline large blocks for longwall extraction. The continuous miner system is used to outline a panel by driving three to five parallel entries on each-side of a panel. The parallel entries on each side of a panel are connected by cross=cuts primarily for purposes of ventillation. Thus, driving one set of parallel entries is analagous to developing a room and pillar production panel. Although both systems drive entries in preparation for longwall extraction, the single entry versus the multiple entry approach requires a different equipment architecture and operating sequence. Existing equipment is limited to driving $20 \mathrm{ft}$ before roof support is required. This is because: (1) continuous mining machines are designed such that driving in excess of $20 \mathrm{ft}$ places the operator and helper under an unsupported.roof, and (2) MSHA regulations do not permit the worker to go under an unsupported roof. Since the tunnel borer drives a continuous entry, the roof support system must be integrated with the boring machine. Therefore, the tunnel borer's architecture provides for the roof support to be installed close behind the cutters. Another major difference between the two systems is the haulage process. Whereas conventional room and pillar systems provide some flexibility in the type of haulage used (such as shuttle cars or conveyors), the single-entry design dictates that a continuous conveyor be employed because of the space constraints. The last major difference between the two systems is the ventilation configuration. The conventional room and pillar layout of entries provides several channels for airflow and escape routes, in the event of a gas explosion or fire. The single-entry tunnel borer provides only one route for airflow and escape. To meet existing MSHA regulations, which require a minimum of two entries for intake and exhaust air and escape, the tunnel borer system divides the entry horizontally for the full length of the tunnel. The construction of the divider requires additional equipment not used in conventional mining.

The detailed discussion of these major differences in terms of equipment design, operation, and manpower requirements is presented in the remainder of this section. This information forms the foundation for the hazard comparisons and injury projections made later in the study.

\section{B. DESCRIPTION OF SYSTEM COMPONENTS}

1. Tunnel Borer

The tunnel borer studied in this report is a mndified version of a boring machine built by the Calweld Manufacturing Co. The total system, 
previously used to drive slopes in the development of new coal mines, meets existing OSHA (Occupational Safety and Health Administration) standards for tunneling equipment and was modified to meet the MSHA (Mine Safety and Health Administration) safety standards (6). This primarily required the installation of water sprays at the face for dust control, the addition of methane monitors, and the partitioning of the tunnel into two entries (one entry for air to reach.the face, the other entry for exhaust). The borer cuts an $18 \mathrm{ft}$ diameter entry using 36 rolling disc cutters. Face material is removed via a spalling process which results in larger fragments and thus better dust control than a continuous miner. Three of the cutters gauge the tunnel diameter, and scraper blades on the perimeter of the cutting head help smooth the tunnel walls. Water sprays provide $50 \mathrm{gal} / \mathrm{min}$ at, or near, each cutter to abate any dust generated while cutting. The tunnel borer also has two protected roofbolting stations located on both sides of the machine, $12 \mathrm{ft}$ from the face. The tunnel borer is trailed by a secondary skid unit that contains the transformer and breaker box, the main electric pump drive motors and hydraulic pumps, which provide the pressure to operate the borer; hydraulic fluid storage tanks, and the operator's station. A third skid, $50 \mathrm{ft}$ long, trails the secondary unit and houses materials for laying track and installing divider support beams. An electrically operated rib drill and a pneumatically operated crane are mounted on the rear of the skid to facilitate the placement and handling of these materials. The crane is also used to move and position the electric degasification drill which is located directly behind the skid. The shotcrete machinery (the spraying unit, batching unit, and mixing unit) is also electrically operated and provides a 3- to 4-in. shotcrete liner which is sprayed over the roof bolts for additional roof support. This equipment is located behind the degasification drill. The next $400 \mathrm{ft}$ of tunnel, behind the shotcrete and degasification equipment, contains the California switch, which is a rail car switching unit consisting of a double track. Rail cars containing support materials are brought in on one track, while muck cars are moved in and out on the other parallel track. A series of sliding, fullwidth, temporary tunnel dividers support an overhead conveyor, which dumps muck through a hopper and into the rail cars approximately $250 \mathrm{ft}$ outby the degas and shotcrete machinery. The last piece of major support equipment in the system, a pneumatically operated crane, is located just behind the hopper in between the rail tracks. This crane is used to move and place permanent flexicore tunnel dividers (pre-stressed concrete beams $161 / 2 \mathrm{ft}$ long, $2 \mathrm{ft}$ wide, and 6 in. thick) on the divider support beams.

The overall length of the tunnel borer system is $640 \mathrm{ft}$. The primary mine power of $7200 \mathrm{Vac}$ must be reduced to $480 \mathrm{~V}$ and $110 \mathrm{~V}$, respectively, for machinery operation and lighting. The hydraulic pumps, which drive the motors for cutter head rotation operate at 2500 psi; while the hydraulic jacks, which support and move the borer, and provide cutter head thrust, operate at 5000 psi. The roof bolters are also hydraulically operated. Figure 2-1 displays the general layout of the complete system.

\section{Continuous Miner}

The major pieces of machinery employed in the multiple entry continuous miner system are: (1) continuous mining machine, (2) loadergatherer (although shown here as a separate component, it is actually an integral part of the continuous miner), (3) bridge conveyor or shuttle car, 


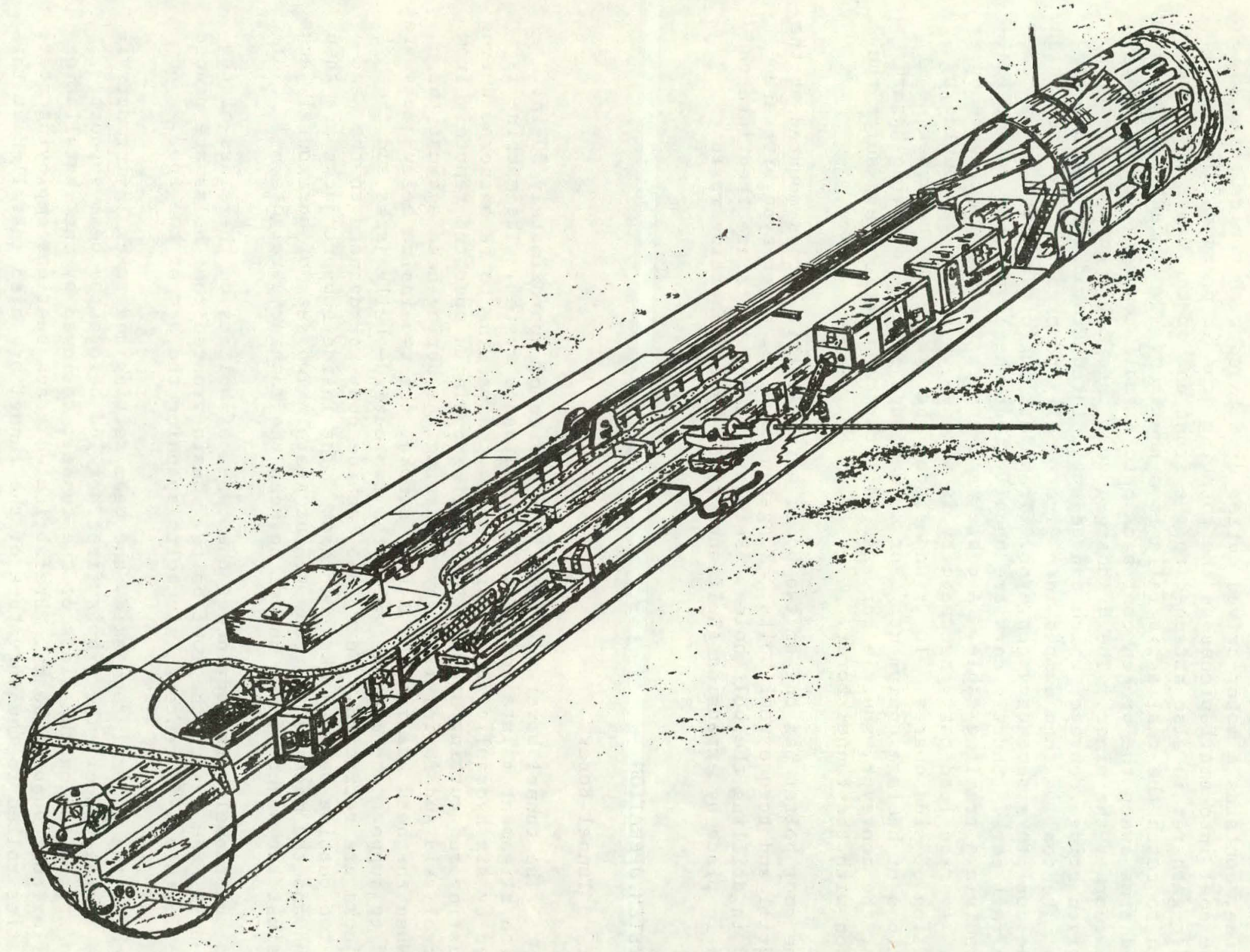

Figure 2-1. Layout of Tunnel Borer Entry Development System 
(4) roof bolter machine, and (5) outby haulage such as rail cars or conveyor (4). The continuous miner is electrically operated and moves either on crawlers or wheels. A hydraulically operated boom, mounted on the front of the machine, contains a motor-driven cutter drum laced with conical bits which break the coal into small pieces as the rotating drum is pressed into the face. The loader-gatherer is also attached to the front end of the miner and forms a large pan to catch the coal as it falls from the face. Two eccentrically coordinated arms sweep the broken coal back onto a small conveyor for discharge from the rear of the miner. The discharged coal then falls onto an electrically driven bridge conveyor which can be articulated around the corners of pillars. The coal is then dumped into electrically powered shuttle cars which carry the coal to a secondary conveyor. Transport out of the mine is by conveyor or rail cars. Shuttle cars are usually four-wheel vehicles, electrically powered via a trailing cable. A cable reel stores the trailing cable on the car. Average load carrying capacity is 6 tons, which can be doubled by the addition of side boards. It is understood that there can be numerous combinations of haulage equipment. For convenience in the following hazard analysis, the conveyor, shuttle car, and rail car combination best suits the comparison with the tunnel borer.

The roof bolter has one or two booms with electric motors mounted at the end to drill and torque roof bolts. Tungsten carbide, auger-type bits are employed in drilling the bolt holes. Reinforcing rod bolts are then inserted and held in place by expansion shell anchors or by fast setting resin.

\section{SYSTEM OPERATION}

\section{Tunnel Borer}

The tunnel borer advances in a series of approximately $30-$ in . steps with alignment maintained by a laser guidance system. The machine is supported by six hydraulic jacks which allow the machine to be anchored during the thrusting and cutting stage. The cutting cycle is operated remotely from the control skid and is initiated by thrusting the boring head against the face. When the head has reached a full stroke, the two inside belly jacks are extended to support the machine while the two outside belly jacks and the thrust jacks are retracted. Next, the machine body is advanced to the head and the two outside belly jacks are reset. The inside support jacks are then retracted and the machine is ready to cut again. Two sets of horizontal jacks push against the sides of the tunnel to keep the machine straight.

As the tunnel borer advances, the two roof bolters on the sides of the machine drill and insert the roof bolts. Resin-grouted roof bolts are placed on approximately 5-ft centers, six bolts spanning the arc of the roof.

Behind the control room skid, the beam setting and track laying activities are taking place. The rib is first drilled before the beam support brackets are bolted on the sides of the tunnel, followed by the installation of the flexicore support beams. Prefabricated track sections employing steel channel ties rolled to the curvature of the tunnel are also installed at this time. The crane, mounted on the back of the skid used for these operations, assists in moving and placing these components. 
As the system advances, the degasification drill bores horizontal holes $1000 \mathrm{ft}$ into the center of the coal seam. These holes are aligned 10 to 15 deg from the horizontal axis of the tunnel, and drilled into both sides of the rib. Liberated gas is channeled into an 8-in. pipeline-and transported to the surface. Each degasification hole has an automatic shutoff valve that is activated if gas sensors, placed along the pipeline, sense greater than $1 \%$ methane. In the event a major roof fall causes pipeline damage, the valves automatically close.

The shotcreting area extends approximately 35 to $90 \mathrm{ft}$ behind the face. Bulk material, such as cement and sand, is brought in on rail cars. The shotcrete is mixed and fed through a hopper before it is sprayed over the roof bolts. As the borer progresses, temporary sliding dividers which rest on the cross beams are shifted out of the way so a thin layer of shotcrete (3- to 4-in. thick) can be sprayed in the upper compartment of the tunnel, up to 35 ft from the face. For added strength, the shotcrete is also sprayed over the beam supports and tunnel walls in the lower compartment.

While the borer is cutting, six pickup buckets on the cutter head remove the face material and dump it into a hopper just behind the head. The hopper feeds the material onto a 36-in. wide conveyor belt which, in turn, transports the material to the hopper $250 \mathrm{ft}$ downstream from the face. Rail cars are automatically spotted under the loading chute attached to the hopper, and eventually transport the coal to the mine mouth.

Since the tunnel divider provides the intake and exhaust passages for the ventilating air, the permanent divider must be placed as the temporary sliding dividers advance with the tunnel borer. The pre-stressed concrete panels are hoisted in place, aligned and locked together through a tongue and groove configuration, and then grouted to seal against air leaks.

To assist workers in operating equipment and performing support tasks, all the work areas in the tunnel are illuminated by $30-\mathrm{W}$ fluorescent lamps which provide an average intensity of $0.06-\mathrm{ft}$ Lambert lumens.

\section{Continuous Miner}

The nominal entry width in underground coal mining is $20 \mathrm{ft}$. The entries are driven parallel to each other on approximately 80-ft centers (4). Crosscuts perpendicular to the entries are usually placed on 100-ft centers (4). The cutting sequence is initiated by sumping the cutter head into the coal face at the top of the coal seam. The depth of the cut is a function of coal hardness and cutter head speed. The cutter drum is moved vertically down the face to the base of the seam, withdrawn, raised to top of the seam, and sumped in again for the next cut. Curcing half of the entry width, the machine drives approximately 15 to $20 \mathrm{ft}$ until the operator approaches the end of supported roof. Subsequently, the machine is backed out and positioned to cut the remaining half of the entry. Temporary support is placed in the mined portion to prevent major roof falls while the second half of the entry is extracted.

As the continuous miner cuts and advances, the coal is gathered by the loader located underneath the cutter drum and discharged onto the bridge 
conveyor attached to the rear of the machine. The bridge conveyor is articulated so it can flexibly move with the continuous miner. Each section of the conveyor is hydraulically steered. The coal is then either transferred directly into shuttle cars (for transfer to a rail car dumping point), or onto another conveyor which dumps into a hopper for rail car loading.

Once the full entry width is cut, the continuous miner and associated haulage equipment are tramed to the next entry where the same cutting cycle is initiated. Workers then place more temporary support in the vacated entry. The roof is then inspected, tested for weaknesses, loose material barred down, and bolt locations are marked. The roof bolter is trammed into position under the marked areas. The drill is inserted and the roof bolter helper assists the machine operator in positioning the boom at the right locations. The roof is then drilled, and bolts are inserted and properly torqued. Upon completion of the roof bolting task, the temporary support is removed and the roof bolter is trammed to the next entry vacated by the miner.

After the bolter has moved to the next entry, battery-powered scoops are sometimes employed to move loose coal toward the face where it can be picked up by the miner when it returns to the area. The scoop and bolter follow the continuous miner from entry to entry until eventually the whole cycle starts again at the first entry.

Face ventilation for gas and dust control must be arranged such that intake air is directed down occupied entries, across the face, and then exhausted down unworked entries. This is achieved by building walls (called stoppings) across old entries and using temporary curtains (called brattice) to close off the appropriate entries near the working areas.

\section{MANPOWER REQUIREMENTS}

\section{Tunnel Borer}

Operation of the tunnel borer encompasses multiple tasks spread across several work areas. The borer is controlled and monitored from the work platform, located directly behind the machine. The two roof bolting stations on the sides of the machine are independently operated and, because there is little room for extra supplies, support material must be frequently carried to these stations from the outby supply cars. The secondary skid, which acts as the work station for the beam installation and track laying activities, requires several workers to assist in drilling and installing beam supports, and handling the cross beams and track sections. Water-pipe laying and power-cable hanging are also performed at this station. The degasification activity requires workers to operate and guide the drill. The shotcreting process calls for several tasks that include operating the batching and mixing machines, reeling hose, spraying shotcrete, and moving materials from supply cars to the batching area. Behind the shotcreting area, near the loading hopper, workers must operate and monitor the conveyor, monitor the loading of cars, and perform cleanup around the hopper. Finally, the installation of the permanent flexicore panels requires several workers to move and position the panels, operate the hoist, and grout the tongue and groove slots against air leaks. The total manpower to perform all of the above tasks is 22 persons (6), and a listing for each task is shown in Table 2-1. 
Table 2-1. Manpower Required by the Tunnel Borer

$\begin{array}{ll}\text { Tunnel borer foreman } & 1 \\ \text { Tunnel borer operator } & 1 \\ \text { Roof bolter operator } & 2 \\ \text { Roof bolter helper (assists bolter } & 1 \\ \text { operators and provides materials) } & 2 \\ \text { Degas drill operator and helper } & \\ \text { Shotcrete crew helper (helps reel } & 1 \\ \quad \text { hose and provides materials) } & 1 \\ \text { Shotcrete crew (conveyor man) } & 1 \\ \text { Shotcrete crew (batch man) } & 1 \\ \text { Shotcrete crew (hose man) } & 5 \\ \text { Shotcrete crew (nozzle man) } & \\ \text { Bull gang (install beam brackets, beams, } & \\ \quad \text { track, flexicore, piping, cable, and tunnel } \\ \quad \text { repairs) }\end{array}$

Total 22

2. Continuous Miner

Entry development tasks associated with the continuous miner system essentially involve operating the continuous miner, monitoring coal loading and articulating the bridge conveyor as the continuous miner moves, cleaning up, providing temporary support, operating the roof bolter, and setting brattice. Associated with the machine operations is the task of cable reeling and handling (kepping the cable from being damaged). The total workforce required for these tasks is 11 to 12 persons (4), and is shown in Table 2-2.

\section{Comparison of the Two Systems}

In comparing the two systems, it appears that some major differences exist in the operation of equipment and design of ventilation. The first major difference stems from the amount of equipment required. Both systems contain the basics; namely, the mining machines, roof support system, and haulage. While, the continuous miner system is essentially completed by these basics, the tunnel borer requires the additional use of material handling hoists, shotcrete machinery, and a degasification drill. This additional equipment leads to the second major difference between the two systems - their respective manpower requirements. The preceding tables suggest that operation of the extra tunneling equipment, particularly associated with the construction of the tunnel divider, increases the number 
Table 2-2. Manpower Required by the Continuous Miner

\begin{tabular}{lc}
\multicolumn{1}{c}{ Task } & Required Personnel \\
\hline $\begin{array}{l}\text { Continuous miner foreman } \\
\text { Continuous miner operator }\end{array}$ & 1 \\
Continuous miner helper (reels cable \\
$\quad$ and assists temporary support activity) \\
Clean-up man and conveyor operator \\
Temporary support man \\
Roof bolter operator \\
Roof bolter helper \\
Brattice man & 1 \\
$\quad$ Total & $2-3$ \\
\end{tabular}

of workers in the system by almost a factor of two. These differences become pivotal factors in the hazard analysis and injury.projections performed later in the study. 
SECTION III

HAZARD ANALYSIS

\section{A. OVERVIEW}

The hazard analysis presented in this section is based on the techniques developed in both the "Safety Evaluation Methodology for Advanced Coal Extraction Systems" and "Health Requirements for Advanced Coal Extraction Systems" $(2,7)$.

The key purpose of any safety evaluation is to understand what hazards might be present in a particular design, and what the sources of those hazards are. The structured approach developed in the above methodologies first requires an identification and evaluation of system failures that can expose workers to substantial hazards. Such failures include machinery breakdown, unpredictable geologic events, and human error. The next step is to systematically identify whether workers may be interacting with the system at the time of failure, since the consequences of these failures may be of such magnitude as to injure workers. This comprehensive approach to identifying hazards is important because it provides a means of discovering hazards unique to a new system.

A comprehensive list of hazards associated with existing equipment was provided in the above references as a general guide to hazard identification. This hazard list was developed by using fault tree analysis and MSHA injury statistics. This list assisted in identifying hazards associated with tunnel borer components used in conventional mining, and also provided a cause and effect logic for understanding how new hazards may occur as a result of unique system failures. This section is primarily directed at the tunnel borer system since the continuous miner hazards are already well documented by historical data $(1,5)$. A hazard comparison of the two systems is provided at the end of the section in preparation for the qualitative design evaluation.

\section{B. TUNNEL BORER SYSTEM FAILURE ANALYSIS}

The three major kinds of system failures identified in the safety methodology. are machinery, geological and environmental (such as rock falls and gas intrusion), and human (2). Machinery can fail as a result of age-reliability degradation or improper design. Geological failures primarily include roof and rib falls resulting from high stresses in the rock strata as the coal is removed, and gas release because of the intersection of gas pockets during the removal of coal. Human error includes inexperience, poor visibility or poor working conditions (e.g., constrained workspace and slippery footing), fatigue, and carelessness.

In analyzing the tunnel borer machine failures, the total system was first separated into the major groupings of machinery, and then each machine was broken down into major components (e.g., cutters, pumps, hydraulics, booms, etc.). Failure data were obtained from discussions with two major tunnel borer users and two major tunneling equipment manufacturers $(8,9,10$, 11). Geological and environmental failures associated with tunneling and coal 
mining were based on discussions with the tunneling contractors and general coal mining experience $(8,9)$. Human errors peculiar to the tunneling industry were also obtained from the tunneling contractors $(8,9)$. Human errors typical of the coal mining environment, and equally applicable to the tunnel borer system, were listed previously in the safety evaluation report and are simply summarized again (2).

\section{Machinery Failures}

As indicated in Section II, the major equipment in the tunnel borer system are; (1) the tunnel borer and control room skid; (2) roof bolters; (3) the beam and track laying hoist; (4) degasification drill and beam support drill; (5) shotcreting machinery; (6) supply and haulage rail cars, and loading hopper; (7) conveyor; and (8) the flexicore installation hoist. Though each one. of these pieces of equipment has hundreds of components, the discussions with the various contractors placed emphasis on those components which contribute to major system breakdowns. Consequently, the following analysis addresses only the dominant failures which contribute to system shutdown or delays.

The major sources of system failures on the tunneling machine revolve around the cutter head, hydraulics, and support jacks. The components most subject to failure on the cutter head are the muck buckets and cutting discs. The muck buckets break and chip because of impact by large rock fragments off the face. Cutter discs fail primarily because of wear. The main shaft bearing, which supports the cutter head, experiences wear as a result of dirt working into the bearing surface.

The key components involved in hydraulic failures are: (1) pumps, (2) relief valves, (3) filters, (4) fittings, and (5) lines. Pump failures center around bearing wear and seal leakage, while relief valves, fittings, and lines fail because of age, or because of accidental impact while performing other maintenance. Hydraulic filters usually require replacement because of contamination introduced during maintenance or while replacing hydraulic fluid.

The hydraulic support jacks for the tunnel borer often experience fatigue because of sustained thrust pressures associated with supporting and stabilizing the tunnel borer. This type of fatigue often results in seal failures and cracks in the support pads.

Conventional electrically operated roof bolters and face drills typically experience failures associated with electrical connections, drive motor burnout, and drill wear or breakage. These are typical problems experienced by the electrically powered drills employed in the degasification and beam installation activities. One additional problem that can contribute to drill breakage is failure to guide the drill properly. This is often the result of the drill intersecting a very hard parting in the strata and being deflected. Roof bolters used with the tunnel borer are hydraulically operated, which shifts the standard electrical failures to hydraulic failures such as line and fitting ruptures, and seal leaks. Drill binding and bit wear are also typical failures with this system. 
As discussed earlier, the operator's control room skid is located behind the tunnel borer and contains the fluid reservoirs and hydraulic pumps that supply pressure to operate the tunnel borer. Typical failure modes of these components were discussed above. In addition to these hydraulic components, the operator's station also contains transformers that provide the power to operate the hydraulic pump motors, lighting, degasification drill, and shotcrete machinery. Trailing cables from the transformer provide power to the various machinery. Electrical failures associated with the transformers and cables are primarily associated with corrosion of terminals (because of acidic airborne moisture), and cable failure at the terminals. Corroded cable leads often break when the leads are periodically removed and cleaned. One design feature of the tunnel borer system which reduces cable failures, is the straight line layout of the equipment, which alleviates cable damage because of abrasion by pillar corners or equipment impact.

The two pneumatic hoists used in the tunnel borer system are typical of cranes used in the tunneling industry. Hoist failures generally center around pressure line ruptures (because of age or being impacted) and hose fitting blowouts. Loss of system pressure can be catastrophic (such as boom collapse) or simply cause system shutdown. Other kinds of hoist failures revolve around age-reliability degradation of components such as gearboxes, braking mechanisms, and the boom. The rate of gear and brake wear is basically a function of the magnitude of the forces transferred to these components through the process of lifting or lowering loads. Similarly, boom fatigue is also a function of load size and load center of gravity in relation to where the hoist cables are attached. For example, hoisting a heavy load at a point off the center of gravity, and allowing the load to swing as it is being moved, can impart large bending and twisting stresses to the boom. Additionally, allowing a heavy load to pendulum in an undamped manner can make it difficult to control the boom and, in a constrained workspace, can result in both load and boom damage if either strikes another object. Other potential failures associated with controlling the load are load slippage and separation of the cables or chains used. for hoisting. These failures are usually the result of not attaching the cables securely, or exceeding the strength of the slings because of overloading or age-reliability degradation. As most of the above components are metal, the fatigue process is accelerated by corrosion, which result from the damp mine environment.

The primary problems experienced with the application of shotcrete and related machinery are; (1) control of the shotcrete layer thickness, (2) pump failure, (3) pressure line blockage, (4) hopper and mixer clogging, (5) mixer plate and spray nozzle wear, and (6) control of rebound and shotcrete dust suspended in the air.

Shotcrete is usually applied to the tunnel wall to improve ground control and prevent weathering and subsequent rib sloughing. If the shotcrete is not applied evenly and to the correct thickness, roof or rib stresses can fracture the shotcrete and subsequently jeopardize roof and rib support. Pump failures usually occur because of bearing wear and motor burnout. Hopper and mixer clogging, and line blockage generally are caused by hardening of residual shotcrete after spraying. Line blockage can result in a pressure line rupture if it is not cleared properly. Mixer plate and nozzle wear result from the abrasive nature of shotcrete. The shotcrete rebound control problem stems. from the high pressure under which the shotcrete is applied. 
Shotcrete deposition on other equipment and the tunnel floor requires continual cleanup. Additionally, the abrasive and corrosive nature of shotcrete aggravates wear and tear on other equipment in the area.

Haulage failures associated with the conveyor, loader hopper, and rail car system make up the final machinery related problems. Conveyor problems are caused by loss of belt tension or belt separation, loss of lubrication on the belt rollers, and drive chain separation. clogging is the main failure experienced by the loader hopper. The rail car system is composed of the battery-powered rail cars and track. Locomotives typically experience battery and switch failures. Another important system failure is rail car derailment, which is due to shifting loads or track discontinuities. The tunnel borer rail system design requires that shotcrete be applied around the track to maintain track alignment. Although this helps prevent lateral movement, it does not adequately prevent vertical movement because of floor heave, which can in turn have undesirable consequences on track alignment. In particular, floor heave can raise the track and cause cracking of the shotcrete, allowing lateral track movement, subsequently contributing to derailments.

The frequency of component failures becomes important when examining worker exposure to hazards. To assist in the safety analysis, Table 3-1 displays the relative occurrence of the various kinds of machinery-related failures in terms of "frequent" or "infrequent". The term "frequent" implies that a given failure is encountered on a daily or weekly basis. "Infrequent" implies that the failure is dealt with on a monthly or yearly basis.

\section{Geological and Environmental Failures}

Most rock falls are smaller loose material that sloughs off the roof or rib. However, stress buildup in the strata, coupled with not placing support in sufficient time, can result in releases of large slabs. Though the tunnel borer is considerably larger than most conventional underground mining equipment, falls of this magnitude would still result in extensive equipment damage. Smaller roof, rib, or face sloughing could cause damage to the cutter head and overhead conveyor; or damage the tunnel borer support jacks. Machine stability problems are caused by sloughed material falling underneath the tunnel borer, creating an unstable support foundation for the jacks.

Another type of geological failure that particularly effects the tunnel borer is rib squeeze, which is the result of large roof stresses being transferred to the side walls of the tunnel. This type of failure results in an excessive loading of the side support jacks, and can result in jack failure or machine entrapment. Similarly, floor heave can result in failure to maintain the machine on the desired horizontal path of the entry. Rock bursts are another type of geological failure related to excessive pressures in the strata. This type of failure can cause serious injury and equipment damage as a result of impact by debris.

Gas or water intrusion are environmental failures which result, respectively, from: ( 1 ) the normal bleeding of methane from coal as it is extracted, and (2) the intersection of a large pocket of trapped water or underground stream. Ignition of gas can result in explosion or fire which can cause extensive equipment damage; and engulfment by water could cause equipment entrapment and power failure. 
Table 3-1. Relative Frequency of Major Machinery-Related Failures

\begin{tabular}{|c|c|c|}
\hline & Relative & Occurrence \\
\hline $\begin{array}{c}\text { Machinery/Component } \\
\text { Failures }\end{array}$ & Frequent & Infrequent \\
\hline
\end{tabular}

Tunne1 Borer

Cutter wear and muck bucket breakage

Main shaft bearing wear

$\mathrm{x}$

Pump bearing wear

Pump seal wear

Relief valve, line, and fitting leakage

Hydraulic filter clogging

Hydraulic support jack seal leakage

Hydraulic support jack pad cracking

Degas and Rib Drills

Drive motor burnout

Electrical connection fouling. $X$

Drill wear

Drill breakage due to guidance problems

Drill breakage due to binding

$\mathrm{x}$

$\mathrm{X}$

$\mathrm{x}$

$\mathrm{X}$

$\mathrm{X}$

$\mathrm{X}$

Roof Bolters

Hydraulic line and fitting leakage $x$

Drill wear and binding

$\mathrm{x}$

Electrical Components

Transformer failure

$\mathbf{X}$

Cable terminal corrosion

$\mathrm{x}$

$\mathrm{X}$

$\mathrm{X}$
$\mathrm{X}$

$\mathrm{X}$

$\mathrm{X}$

$\mathrm{X}$

Cable failure due to abrasion or

impact by other machinery

$\mathrm{X}$

Pneumatic Hoists

Pressure line and fitting ruptures

$\mathrm{X}$

Gearbox and brake wear

$x$

Boom fatigue resulting in cracking

$\mathrm{X}$

$\mathrm{x}$

Load instability

$\mathrm{x}$

$x$

$\mathrm{x}$


Table 3-1. (Cont'd)

Machinery/Component

Failures
Relative Occurrence

Frequent Infrequent

\section{Shotcrete Machinery}

Control of shotcrete thickness

Pump failure

Pressure line blockage

Hopper and mixer clogging

Mixer plate and nozzle wear

Shotcrete rebound

Haulage

Loss of conveyor belt tension

Conveyor belt separation

Loss of lubrication on belt rollers and chain drive

Drive chain separation

Clogging of loader hopper

Rail car battery and switch failure

Track misalignment

Derailment $\mathrm{x}$

$x$

$x$

$\mathrm{x}$

$\mathrm{x}$

$\mathrm{X}$

$\mathrm{X}$

$\mathrm{X}$

$\mathrm{X}$

$\mathrm{x}$

$\mathrm{X}$

$\mathrm{x}$

.

$x$

$\mathrm{x}$

$\mathrm{X}$

$\mathrm{X}$

Although it is understood that the incidence and magnitude of geological and environmental failures are site specific, Table 3-2 displays the general frequency of these kinds of failures relative to each other under normal tunneling and mining conditions. Again, the term "frequent" implies that workers encounter these problems on a daily or weekly basis; whereas "infrequent" suggests a time frame of months or years between failures.

\section{Human Error}

Although human error can sometimes be traced to carelessness, the mine environment in which workers operate machinery and perform support tasks contributes equally to the problem. Human error can often be the result of inexperience, or bad working conditions, such as poor lighting, constrained work space, or fatigue. Typical sources of human errors in contemporary underground coal mining are as follows (2):

(1) Lack of experience on how and where to set ground control components.

(2) Choice of tools poorly suited for a given task. 
Table 3-2. Relative Frequency of Geological and Environmental Failures

Relative Occurrence

Geological/Environmental

Failures

Frequent Infrequent

$\begin{array}{lll}\text { Small-scale roof, rib, or face sloughing } & \mathrm{X} & \\ \text { Large-scale roof falls . } & & \mathrm{X} \\ \text { Large-scale rib squeeze } & & \mathrm{X} \\ \text { Floor heave } & & \mathrm{X} \\ \text { Rock bursts } & \mathrm{X} & \mathrm{X} \\ \text { Gas intrusion } & & \end{array}$

(3) Handling cumbersome materials on loose or slippery footing.

(4) Inexperienced or careless operation of machinery.

(5) Inadequate visibility of operations, because of poor lighting or other obstacles, during machine operation.

(6) Workers trying to move objects or tools too quickly and drop them.

(7) Constrained or poorly lit work area, not allowing workers to monitor other events taking place in the immediate vicinity.

These sources of human error can result in system failures related to: (1) improperly maintained machinery, (2) not being able to properly control machinery, and ( 3 ) breakage of hand tools, machinery components, or support materials. With the exception of errors associated with setting ground components and poor lighting, all of the above causes of human error in conventional mining are equally applicable to the tunnel borer system. For example, the tunnel borer is remotely operated from the control room skid located behind the machine. Setting the hydraulic support jacks in the wrong sequence can result in: (1) improper guidance of the system, (2) excessive stress on the support jacks, or (3) allowing the machine to tip forward onto the cutter head. Similarly, moving loads attached to the hoists too quickly, or not observing proper clearance between the load and the tunnel wall, can result in impacting the tunnel wall or other objects. During the shotcrete operation it is imperative to control the direction of the high pressure flow. Not properly observing the direction of the stream, or losing control of the nozzle due to recoil or pressure fluctuations in the hose, can result in damage to other equipment or the main electrical cable. Although the frequency of these human errors is difficult to assess, it is important to understand their role in increasing stress on equipment and resultant system failures. 


\section{HUMAN INTERACTION WITH SYSTEM FAILURES}

The degree of interaction between system failures and workers determines the presence of particular hazards. Worker interfaces with potential system failures occur through the various tasks performed. These tasks range from equipment operation to support tasks; such as material handling, cleanup, and maintenance. Section II-C introduced the principal activities associated with tunnel borer operation. This section defines these activities in greater detail and relates all of the tasks to the system failures described above.

\section{Machinery Failures}

The most frequent failures in the cutter head area are related to the muck buckets and cutter discs. Workers interface with these failures in the process of replacing or welding the muck buckets, or while dressing or replacing the cutters. Since the tunnel borer is not very mobile, this type of maintenance must be done in the face area. Although the failure of the main shaft bearing is infrequent, replacement is a major task usually requiring removal of the cutter head to gain access to the bearing. Again, this task must be performed in the face area. Components such as relief valves, lines, fittings, and filters are the high-frequency failure items in the hydraulic subsystem. Workers interface with these failures when performing routine checks and unscheduled maintenance on both the tunnel borer machine and control room skid. Hydraulic pump replacement is usually contained to the control room skid. Maintenance on the support jacks requires workers to remove the main support column to gain access to the seals. If the belly jack seals require replacement, additional jacks must be placed under the machine while the seals are removed. Stress cracks in the support pads or main support columns can usually be welded.

The high-frequency failures associated with the degasification and rib drills center around electrical connections and drill wear or breakage. Workers interface with these respective failures while cleaning and checking connections and while removing and replacing worn or broken drill sections. The hydraulically powered roof bolters are attached to guide rails on the borer and are usually repaired in place. These repairs typically involve replacement of leaking seals or pressure lines, as well as worn or broken drills.

Standard maintenance on the transformers in the control room require workers to check and clean all electrical connections. Though cable failures are infrequent, workers must still check and clean all terminals to which the trailing cables are attached. The main power cable leading to the $480-\mathrm{V}$ transformer must be securely attached to the rib as the tunnel borer advances. Workers perform this task while installing the beam support brackets and beams.

Pneumatic hoist failures can involve a wide range of worker activities. Additionally, Section II-D identified a large number of workers associated with the track, beam, and flexicore installation tasks. In performing these tasks, workers must manually lift the components to attach the hoist slings, guide the component in place, and secure it. Consequently, the hoist operators and helpers are working in the vicinity of the boom, the moving 
load, and the pressure lines. Other tasks performed in the immediate vicinity of the hoists are the degasification, shotcreting, and haulage operations. Hoist maintenance usually involves scheduled checks of pneumatic fitting connections, periodic replacement of worn or damaged pressure lines, boom inspection to locate corrosion or stress cracks (and welding as required), lubrication, and periodic inspection and replacement of hoist slings. All of the hoist maintenance is done in place.

The shotcreting operation also involves several workers. As stated earlier, the most frequent failures are related to line blockage, hopper and mixer clogging, mixer plate and spray nozzle wear, and rebound. Workers interface with line blockage and possible pressure bursts while spraying the shotcrete, and monitoring the batching and mixing process. Hopper and mixer clogging require workers to periodically unjam and clear the residual concrete. Mixer plate and nozzle wear are maintenance items requiring periodic replacement. The rebound and spray control problems not only involve the immediate nozzle man and helper, but can also interface with workers performing the degasification, and beam and track laying activities. The clearing of excessive amounts of rebound is a pick and shovel cleanup task.

Haulage failures occur largely in the conveyor belt area. Workers must periodically adjust belt tension, inspect for belt wear, replace belt sections, and lubricate the rollers and drive chain. With the exception of belt replacement, these tasks are usually done while the belt is operating. In conjunction with the inspection task, workers often clean up spillage around the belt and in the hopper area. Rail car maintenance generally involves removing, replacing, and testing. batteries and switches. Battery maintenance also includes checking water levels and cleaning the terminals. Track maintenance requires workers to clean spillage off the tracks, and to periodically replace ties and worn track. Raising track sections and leveling the foundation to maintain track alignment are also part of track maintenance activities. Although rail car derailments are infrequent, workers interface with this system failure during rail car operation, and when hoisting or jacking the cars back in place. Correcting a derailment often requires reloading the gob by hand into the cars.

\section{Geological and Environmental Failures}

As indicated in the discussion on geologic failures in section III-B., roof, rib, and face sloughing occur frequently. Under normal conditions, the combination of roof bolts and shotcrete will prevent roof and rib sloughing up to $35 \mathrm{ft}$ from the face (which is where the shotcrete ends). As roof bolts are placed $12 \mathrm{ft}$ from the face, only the boring machine, first conveyor stage, and roof bolting stations are exposed to impact.by falling rock. Thus, workers are exposed to potential rock falls while performing maintenance on the cutter head or support jacks, while operating or maintaining the roof bolters, and while maintaining or performing cleanup around the first stage conveyor. As stated in the section pertaining to system description, the roof bolting stations are protected. This does mitigate the fall problem substantially. Additionally, the side support jacks assist in preventing any sizable rib slough. However, workers are exposed to roof slough while removing fallen 
debris away from the side and belly support jacks. In the event of major rib squeeze, workers are required to place explosive charges in the rib in order to free the machine. This activity also requires a large amount of cleanup once the machine is dislodged. Cleanup and leveling is also required in the event of floor heave.

Another frequent environmental failure is the intersection of methane pockets and release of gas into the face area. In the event of explosion or fire, the operator, roof bolters and helper, and cleanup personnel will be exposed to serious injury. Depending on the size of the gas pocket and rate of propagation of the resulting explosion and fire, workers performing shotcreting and beam and track installation could be impacted as well.

\section{Human Error}

Human errors that occur while maintaining, operating, or moving equipment can involve either a direct interaction (such as dropping an object on another worker in the area), or an indirect interaction (such as improperly operating machinery, resulting in an equipment failure which impacts other workers). Examples of possible direct interaction type human errors associated with the tunnel borer system are as follows:

(1) Worker handles a machine or support component (such as a cutter disc, drill bit or drill section, beam support bracket, beam, water pipe section, flexicore) by himself or with another worker at an elevation, or on poor footing, slips and drops component.

(2) Worker improperly applies a tool or special support equipment (such as a jack for propping up a track section, or jacking up the tunnel borer) for maintenance or cleanup, and the 0001 slips or breaks.

(3) Worker cannot properly control the shotcrete spray direction because of recoil in the hose while other workers are performing tasks in the immediate vicinity.

(4) Worker operates hoists or haulage machinery and is not able to observe other workers in the vicinity due to poor visibility or obstructions.

Examples of errors involving indirect interactions are as follows:

(1) Worker operates machinery improperly, or at a faster rate than specified, resulting in an equipment failure (such as not controlling the swing rate of the hoist boom and impacting the tunnel wall while other workers are working near the rib; or, operating rail cars too fast resulting in derailment while workers are performing track repairs in the immediate vicinity).

(2) Worker operates machinery improperly resulting in an equipment failure, which in turn exposes workers to other kinds of system failures (such as improperly sequencing the support jacks, 
exposing workers to potential rock falls while jacking up the borer to realign the cutter head at the face).

(3) Workers improperly maintain equipment, resulting in equipment failure, which subsequently exposes workers to other kinds of system failures (such as not checking the belt tension or not lubricating the conveyor drive chain and rollers, requiring workers to interface with rock falls in the first stage overhead conveyor area).

In examining all the various worker interactions with machinery, geologic, and human failures, the potential hazards associated with the tunnel borer system become evident. The next section draws on this information, as well as historical data, to determine more precisely the nature of each hazard.

\section{HAZARD IDENTIFICATION}

Identification of hazards follows directly from the analysis of worker interaction with system failures. Historical injury data are an additional source of information that help confirm the existence of suspected hazards. Since the tunnel, borer system contains components used in contemporary mining (such as roof bolters, transformers, electrical cables, conveyors, and rail cars), MSHA injury statistics tabulated by worker activity were useful in substantiating hazards related to this equipment (5). Injury statistics involving other components such as the borer, degasification drill, hoists, and shotcrete machinery were obtained from the Safety Division of the Bureau of Reclamation in Denver, Colorado (12). The Bureau of Reclamation is responsible for monitoring and tabulating injuries for all tunneling operations west of the Mississippi River. Four years of tunneling injury data provided a substantial base from which to confirm hazards representative of equipment used in the tunneling industry.

Before listing the hazards associated with the tunnel borer system, the following cause (system failure and worker interaction) and effect (hazard) relationships are provided to demonstrate how hazards are generated. For example, one interaction with machinery failures discussed in the previous section was the improper operation of the hoist. The cause of the hazard would be; "swinging boom strikes tunnel wall while workers are installing beam support brackets and beams". The resultant hazard would be; "workers are in a position to be struck by collapsing boom or falling load." One cause- and effect-relationship related to the degasification drill is as follows: "workers are operating degas drill when drill stem breaks - workers in a position to be struck or caught by broken drill fragment". This hazard would also apply to the rib drill and roof bolters. The shotcrete operation exhibits the following hazard: "workers are operating shotcrete equipment when line blockage causes pressure line rupture - workers in a position to be struck by shotcrete spray and whipping hose". An example of a hazard generated by a geologic failure would be: "workers are performing maintenance on the muck buckets or cutter discs at the face - workers in a position to be struck by roof or face fall". Similarly, all the various kinds of system failures and worker interactions can be translated into potential hazards. Additional details of how to identify and characterize hazards are provided in the safety methodology employed for this analysis (2). The following is a 
comprehensive list of hazards associated with the tunnel borer system. Hazards related to machinery failures are grouped by equipment type. Hazards involving geologic or other environmental events are grouped separately.

\section{Hazards Related to Machinery Failures and Associated Human Errors}

a. Tunnel Borer. Worker in a position to be struck by a machine component as a result of :

- Other workers handling cutter discs, pumps/pump motors, muck buckets, or support jack components during maintenance.

- Worker being required to handle a heavy machine component while replacing or repairing it.

- Workers not using appropriate support equipment (such as small hoists or carrying slings) when handling heavy components.

- Worker's physical capabilities being exceeded because of weight or size of cutter discs, muck buckets, or support jack components.

- Worker on wet or loose footing while handling cumbersome machine components, and slipping or falling.

Worker in a position to be struck by a tool as a result of:

- Hydraulic jacks slipping or breaking while being used to prop up the machine during realignment, or support jack maintenance.

- Slippage or breakage of tools (such as wrenches, crowbars, hammers, etc.) used for removing cutter discs, hydraulic lines, muck buckets, or support jack components.

- Worker applying excessive force causing tool to slip or break, or causing object worked on to break.

- Worker engaged in maintenance (such as wrenches, hamers, crowbars, etc.) dropping tool on self or other worker.

- Worker prying loose rock away from support pads or cleaning up debris under tunnel borer and breaking or dropping the pick or shovel.

Worker in a position to be struck by flying debris from object worked on as a result of:

- Prying or moving loose rocks away from support pads or under the cutting machine and being struck by rock fragments.

- Welding muck buckets, cutter discs, or support pad components and being struck by hot metal fragments.

Worker in a position to slip or be knocked off balance as a result of:

- Handling cutter discs, muck buckets, or support jack components on poor footing.

- Being struck by tool in the hands of other worker. 
- Performing cleanup around the tunnel borer and slipping or tripping on debris.

o Being struck by roof, rib, or face slough.

Worker in a position to be struck by high pressure release from machinery as a result of: -

- Failure of hydraulic lines or seals in the control room area, or while checking or replacing hydraulic lines and fittings on the tunnel borer.

- A whipping hydraulic line ruptured while performing maintenance on pressure lines and fittings.

While performing maintenance or cleanup around the support jacks, worker is in a position to be struck or caught by the miner as it advances.

Worker in a position to be in contact with an energized conductor as a result of:

- Cleaning, checking, or troubleshooting the transformers.

- Cleaning the transformer terminals and checking for cable lead corrosion or breakage.

Worker in a position to inhale coal dust as a result of operating the borer, or performing maintenance and cleanup in the face area.

b. Roof Bolter. Worker in a position to be struck by a machine component as result of:

- Handling or replacing the drill bit and dropping it.

- Handling roof bolt and dropping it.

- Roof bolter helper handling supplies and dropping them on self or operator.

- Drill or roof bolt binding and breaking.

Worker in a position to be struck by a toul as a result of:

o Worker removing or tightening hydraulic fittings and wrench slips or fitting breaks.

- Worker performing maintenance such as tightening drill or replacing hydraulic lines and drops tool on self or roof bolter helper.

- Worker prying down loose rock and crowbar slips or breaks.

Worker in a position to be struck by flying debris from object worked on as a result of:

- Being struck by rock fragments during drilling.

- Worker barring down loose rock and is struck by rock fragments.

Worker in a position to slip or be knocked off balance as a result of:

- Being struck by a broken drill segment or rock fragment. 
- Worker operating or moving roof bolters and slips on dribris. - Worker inadvertently strikes another worker while handling drill or roof bolts.

- Tool slipping while tightening drill or hydraulic fittings.

o Worker struck by rock fall.

Worker in a position to be struck by high pressure release from machinery as a result of:

- Severed hydraulic lines, or improper repair or maintenance of pressure lines and fittings.

- Impact by a whipping pressure line.

Worker in a position to be struck or caught by machinery as a result of:

- Being struck by the roof bolter while assisting the operator in sliding the bolter on its track.

- Operator or helper's clothing being caught by rotating drill.

- Operator or helper being caught by bolt plate while

installing and torquing roof bolt.

Worker in a position to inhale coal or rock dust as a result of respirable dust generated by miner, roof bolters, and conveyor.

c. Pneumatic Hoists. Worker in a position to be struck or caught by equipment, or hoisted components, as a result of:

- Workers handling beam brackets, beams, track section, pipe, or flexicore and dropping component on self or other worker.

- Hoist cables breaking and whipping, or load being dropped.

- Loss of system pressure causing boom to fall.

- Operator moving boom or load too quickly, impacting rib and causing boom to collapse or load to fall.

- Operator not seeing workers in area and impacting workers with boom or load.

Worker in a position to be struck by a tool as a result of:

- Worker replacing pressure lines and wrench slips or fitting breaks.

- Worker replacing damaged pressure lines, or repairing boom, and drops tool on self or on other workers.

Worker in a position to be struck by flying debris from object worked as a result of worker performing weld repairs on boom and being struck by hot metal fragments.

Worker in a position to slip or be knocked off balance as a result of:

- Being struck by swinging boom or load. 
- Worker performing maintenance on elevated section of boom and losing balance.

- Workers handling beam brackets, beams, pipe, track, or flexicore and slipping after dropping component.

- Standing on curved rib while installing beam and pipe.

Worker in a position to be struck by high pressure release from machinery as a result of:

- High pressure air from ruptured line or blown fitting.

- Impact by whipping pressure line.

d. Degasification and Rib Drills. Worker in a position to be struck by a component as a result of:

- Handling drill bit, or drill section, and dropping component on self or other worker.

- Drill binding and breaking.

- Beam support bracket slipping while installing bolts.

- Being struck by falling hoist load while operating drills.

Worker in a position to be struck by a tool as a result of:

- Worker tightening drill or rib bolts and wrench slips or breaks.

- Worker performing maintenance on drill and dropping tool on self or other worker.

Worker in a position to be struck by flying debris from object worked on as a result of flying rock fragments while drilling the rib.

Worker in a position to slip or be knocked off balance as a result of:

- Being struck by drill or fragment of broken drill.

- Being struck by the degasification drill while hoisting and repoeitioning drill.

- Tool slipping while tightening drill.

- Being struck by hoist boom or falling hoist load while operating drills.

- Standing on curved rib while operating drill and installing beam support brackets.

Worker in an position to be struck or caught by machinery as a result of:

- Being struck by the degasification drill while operating, or repositioning drill using the hoist.

- Operator or helper's clothing being caught by rotating drill.

- Operator or helper being caught or pinched by rib bolt while. inserting and torquing. 
Worker in a position to be in contact with an energized conductor as a result of:

- Checking for cable lead corrosion, or breakage.

- Cleaning and tightening terminal connections.

- Troubleshooting motor or electrical connection problems.

e. Shotcrete Machinery. Worker in a position to be struck by machine component as a result of:

- Worker handling spray nozzles, mixer plates, or conveyor components during maintenance and dropping them on self or other worker.

- Worker slipping on wet footing and dropping component on self or other worker.

Worker in a position to be struck by a tool as a result of:

- Workers using wrenches, hamers, etc., while replacing nozzles, conveyor components, or mixer plates, and dropping them on self or other worker.

- Worker applying excessive force while removing and replacing components, or while removing residual concrete from hopper and mixer, causing tool to slip or break or object worked on to break.

- Worker unclogging hopper and mixer and being struck by jammed tool.

- Worker performing cleanup of rebound off tunnel walls and floor and dropping pick or shovel on self, or being struck by tool while prying rebound loose.

Worker in a position to be struck by flying debris from object worked on as a result of:

- Worker unclogging hopper and mixer and being struck by flying shotcrete fragments.

- Workers prying rebound off walls or floor of tunnel and being struck by flying shotcrete fragments.

Worker in a position to slip or be knocked off balance as a result of:

- Handling machine components on wet footing while performing maintenance.

- Slipping on wet rebound while handling the hose and spray nozzle.

- Performing cleanup and slipping on wet rebound.

o Being struck by tool in the hands of other workers while performing maintenance or cleanup.

- Carrying bags of concrete from supply cars to the batching area, and slipping on poor footing.

- Being accidentally struck by nozzle spray.

- Being struck by ruptured shotcrete hose. 
Worker in a position to be struck by high pressure release from machinery as a result of:

- High pressure release of shotcrete from ruptured hose or burst fitting.

- Nozzle man not seeing other workers in the area, or losing control of the nozzle because of recoil or pressure fluctuations in the hose.

- Impact by whipping hose after line rupture.

- Nozzle man or helper being too close to spray surface and being struck by rebound.

Worker in a position to inhale shotcrete or have shotcrete contact skin as a result of:

- Shotcrete not being properly mixed resulting in respirable dust and hardener suspended in the air.

- Being struck by shotcrete rebound.

- Opening cement bags, dumping cement in hopper, and mixing concrete and hardener in open mixer.

- Not wearing adequate protective clothing when in the shotcreting area.

Worker in a position to be struck or caught by machinery as a result of:

- Unclogging operating hopper and mixer and catching loose clothing or hands.

- Catching loose clothing or hands in moving conveyor.

Worker in a position to contact energized conductor as a result of troubleshooting pump or motor drive problems, or checking and cleaning electrical terminals.

f. Haulage Equipment. Worker in a position to be struck by a machine component as a result of:

- Handling conveyor drive chain, rollers, or rail car batteries during maintenance and dropping component on self or other worker.

$0 \quad$ Exceeding his physical capabilities because of the weight and size of conveyor components or batteries.

- Slipping and falling on poor footing while handling components.

Worker in a position to be struck by a tool as a result of:

- Tools (such as wrenches, screwdrivers, hammers, etc., used for maintenance on the conveyor drive chain, rollers, adjusting belt tension, or removing battery cables) slipping and striking worker or helper. 
- Tool slipping or breaking due to worker applying excessive force.

- Worker adjusting conveyor belt tension or drive chain tension while belt is operating and catching tool in moving machinery.

- Jacks or hoists used for rerailing rail cars or raising track section slipping or breaking.

- Workers cleaning up spillage around conveyor, catching tool in conveyor, and conveyor deflecting tool.

- Worker dropping tool or striking helper with tool during cleanup after derailment.

Worker in a position to be struck by flying debris from object worked on as a result of:

- Workers cleaning up spillage around conveyor, rail cars, or loading hopper and being struck by muck.

- Workers chipping away shotcrete from track while doing track repairs.

Worker in a position to slip or be knocked off balance as a result of:

- Performing cleanup around hopper, conveyor, or rail cars and slipping on bad footing.

- Being struck by falling debris while cleaning up around hopper.

- Being struck by tools such as shovels or jacks used for cleanup and rerailing cars.

- Being struck by moving rail cars during track repair or flexicore installation.

Worker in a position to be struck or caught by haulage machinery and related components as a result of:

- Installing or repairing track and being struck by track section, track, or rail ties.

- Being struck by moving or derailed cars while performing track maintenance or installing flexicore.

- Rail car operator being pinched between car and rib during derailment.

- Lubricating conveyor rollers and drive chain, or adjusting belt tension, and catching loose clothing or hands in moving machinery.

Worker in a position to contact an energized conductor as a result of:

- Replacing switches and batteries.

- Checking battery power output. 
Worker in a position to be burnt as a result of:

- Placing a tool across battery terminals.

- Ignition of hydrogen released while charging battery or checking its water level.

2. Hazards Related to Geologic and Environmental Failures

a. Geologic Failures. Worker in a position to be struck by roof, rib, or face rock as a result of:

- Performing maintenance on muck buckets or cutter discs, or realigning the mining machine, in the face area.

- Performing cleanup around the tunnel borer support jacks in the face area under unsupported roof.

- Roof bolters installing bolts or barring down loose rock beyond point of last permanent support.

- Performing cleanup or maintenance on first stage conveyor and being struck by loose rock or shotcrete fragments that fall with rock.

- Unusual geologic conditions encountered such as air, gas, or water pockets under high pressure.

b. Environmental Failures. Tunnel borer operator and roof bolters are in the area of methane release and:

- Poor ventilation causes gas buildup at face where tunnel borer cutting operation generates sparks, causing gas ignition and explosion.

- Gas monitor fails to detect an excessive amount of gas subsequently causing explosion.

- Degasification drill is deflected by hard parting in the rock and intersects face area, allowing gas to leak into cutting area, resulting in ignition.

- Workers are struck by flying rock fragments resulting from explosion.

- Gas is ignited causing flammable hydraulic fluid to catch fire, exposing workers to burns.

\section{E. COMPARISON OF HAZARDS}

As stated in the previous section, hazards related to the continuous miner have been documented in MSHA injury data (5). Examining this historical evidence and comparing it with the tunnel borer hazards reveals the similarities and differences between the two systems. As shown in Section II.B., the continuous miner system is basically composed of: (1) the continuous miner, (2) the attached loader, (3) bridge conveyor or shuttle car, (4) roof bolter, and (5) rail cars or fixed conveyor. The rail car component 
of the system is exactly the same as the tunnel borer and therefore experiences basically the same hazards associated with maintenance and operation of this subsystem. One slight difference is that the continuous miner system also usually employs additional rail cars operating off a trolley line to assist in moving workers and supplies to and from the face. This component demonstrates the same hazards related to impact by rail cars, with the additional hazard of workers contacting the energized trolley wire.

Although the conveyor and roof bolter components are also employed in the tunnel borer system, there are some substantial differences in the hazards associated with this machinery. These differences stem from: (1) the continuous miner bridge conveyor being located in the immediate working area, and being capable of articulation, and (2) the roof bolter being a separate, electrically powered machine. The tunnel borer conveyor is mounted overhead and away from the normal working area. Therefore, workers experience the hazards of being caught or struck by the conveyor only when doing periodic maintenance or cleanup. However the continuous miner bridge conveyor, being in the working area, exposes workers to these hazards constantly. The hazard of being struck by the bridge conveyor is aggravated by the articulated design feature. This is primarily because the bridge conveyor, in its articulated mode of operation, is subject to rapid, jerky lateral movements. Since the bridge conveyor moves with the continuous miner, it is often difficult to determine what direction and distance each respective section of the conveyor will travel.

Roof bolter hazards in a continuous miner section are aggravated because workers are exposed to impact by the machine while it is tramming, moving in position in the face area, or operating. The tunnel borer roof bolters are integrated with the miner and constrained to move only in an arc; however, the conventional roof bolter moves independently of. the miner and is subject to rapid, uncontrollable movement as a result of lateral forces imparted on the bolter while drilling. Additionally, conventional roof bolters are electrically powered and subsequently expose workers to electrical hazards while handling the power cable or doing machine maintenance.

Both the tunnel borer and continuous miner systems employ transformers and power cables to operate various equipment. Although the electrical hazards are the same, the layout of the tunnel borer equipment places cables in relatively undisturbed loations. Cable handling is a major task in the continuous miner system because equipment is constantly moving and changing positions. As a result, hazards associated with handling energized cables are aggravated.

The continuous miner system does not employ pneumatic hoists, degasification drill, or shotcrete machinery and, therefore, does not experience hazards related to this machinery. Though workers performing support activities in the continuous miner system do not install flexicore components, they do handle similarly sized components such as beams, timber, and temporary support jacks during the roof support operation. Consequently, hazards associated with handling heavy, cumbersome components, and using handtools to install these components, equally apply to both the tunnel borer and continuous miner. Hazards related to maintenance of equipment (such as tool hazards, electrical hazards, or handling machine components) also apply to both systems. Since both systems employ hydraulics, the hazards of being struck by a high pressure stream of fluid or whipping hose are the same. It 
appears, however, that these hazards are somewhat aggravated in the tunnel borer system by the more extensive use of high pressure pneumatics and hydraulics.

Although the hazards connected with the operation and maintenance of the continuous miner are basically the same as the tunnel borer machine, certain operational aspects of the continuous miner complicates the machinery hazards. The complications arise from the mobility of the continuous miner and the location of the operator. The continuous miner is subject to rapid backward, forward, and lateral movement. The rapid backward and forward movement occurs while sumping and changing position. The lateral movement is usually caused by striking a hard parting in the coal seam. Additionally, the operator is seated in a cab located on the side of the machine, thus reducing his visibility of the work area opposite the cab. As a result, workers installing temporary support, carrying supplies, or cable handling may be struck by the miner. The operator is also exposed to being pinched between the rib and cab, or struck by haulage machinery in the area, while leaning out of the cab to back out or maneuver the miner. These hazards are not as acute with the tunnel borer since the machine is: (1) considerably larger and constrained to move in one direction, (2) slow moving, and (3) the operator remotely controls the machine from the control room skid.

The shuttle car is the last piece of machinery in the continuous miner system, but is not used in the tunnel borer system. The hazards normally associated with this component are: (1) workers being struck by the machine while working in the face area, (2) the shuttle car operator or helper being pinched between the rib and vehicle while maneuvering, (3) the shuttle car striking workers because the operator does not see them, (4) brake failure or mechanical malfunction that causes the shuttle car to go out of control and strike workers, and (5) the shuttle car going out of control after hitting an obstacle, such as a fallen rock.

The hazards connected with geological and environmental failures are the same for both systems. The major advantage of the tunnel borer stems from joint use of roof bolts and shotcrete. Together these provide continuous roof and rib support for the length of the entry. Additionally, the shotcrete layer helps prevent gas seepage into the entry.

In summary, it appears that both systems experience the same hazards associated with machinery and geological failures. The differences between the two systems arise from the degree to which the various components of each system complicate or intensify the respective hazards. For example, the tunnel borer appears to reduce the magnitude of hazards related to geologic failures, the conveyor, roof bolters, and electrical cables. At the same time, the borer appears to intensify machinery hazards because of the additional use of the degasification drill, hoists, and shotcrete machinery. This suggests that the tunnel borer represents a greater source of machinery hazards. Whether the tunnel borer can be considered as a viable replacement system for the continuous miner will be a function of identifying design elements that mitigate machinery and other hazards. Before performing the quantitative evaluation, a qualitative analysis of the design, considering the results of the hazard analysis, provides an indication of positive and negative design elements. The qualitative design analysis is provided in the following section. This analysis establishes the foundation for quantifying design elements and projecting injuries later in the evaluation. 


\author{
SECTION IV \\ QUALITATIVE HEALTH AND SAFETY EVALUATION
}

\title{
A. OVERVIEW
}

The previous section established the hazards associated with the tunnel borer sytem. The next step is to determine whether the design is basically sound in terms of existing regulatory constraints, and whether the design offers health and safety improvements that offset major hazards. This step is a continuation of the qualitative evaluation begun in the hazard analysis. At the completion of the qualitative evaluation, the regulatory integrity will have been confirmed, and both the strong and weak points of the design identified, thus, permitting an initial judgment about the likely health and safety performance.

\section{B. SELECTION OF AN ANALOgOUS SYSTEMS}

In order to assess whether a new design meets the intent of current regulations, it must be compared to a similar existing system. The Safety Methodology (2) groups comparisons into two categories: systems that are functionally similar, and systems that are nonfunctionally similar. The distinction is as follows:

(1) Functionally similar systems operate in exactly the same environment, in essentially the same fashion, and have similarly structured components. For example, two longwall systems: one a shearer, and the other a plow.

(2) Nonfunctionally similar systems have only one thing in common; they both may either extract or haul coal. Nonfunctional comparisons have totally different component structures and are relevant only if the new technology is so different that a functional comparison is unavailable, or if the new system is intended to replace a conventional system that appears inherently more hazardous.

At the onset of the study it was determined that the single-entry tunnel borer system would be examined with the intent of replacing the conventional continuous miner five-entry system. At the system level, evaluating the continuous miner against the tunnel borer represents a nonfunctional comparison. However, the conveyor, rail car, and roof bolter components of the tunnel borer system are state-of-the-art technology employed in conventional mining and can, therefore, be compared on a functionally similar basis. Although other tunnel borer system components such as the hoists, rib and degas drills, and shotcrete machinery are not usually employed in coal mining, functionally similar components exist in the tunneling industry. The tunneling industry, therefore, provides an additional basis for comparison of regulatory conformance. 
The regulatory evaluation of the tunnel borer system is simplified by the fact that the system is essentially a different application of state-of-the-art hardware. As noted in Section II, the tunnel borer is a modified version of a Caldweld boring machine, which is used for tunneling and driving slopes. Consequently, the machine already meets existing tunneling regulations established by OSHA. The following modifications to the machine were necessary to meet MSHA safety regulations:

(1) Installation of ventilation fans on the boring machine to ensure that a minimum air flow of $9000 \mathrm{ft}^{3} / \mathrm{min}$ is provided at the face.

(2) Installation of a water spray system for dust abatement.

(3) Installation of roof bolters on the machine to provide permanent. roof support in accordance with the Title 30 (MSHA Safety Regulations) bolting regulations.

(4) Demonstration that the power transformer on the control skid properly interrupts if struck by a rock fall. (this was done by on-site testing).

(5) Addition of a tunnel divider to provide a minimum of two entries, one for intake air and the other for exhaust.

Dust collection systems were.added to the bolters to improve dust control at the face. Other equipment such as the conveyor and rail cars, and roof bolters are standard coal mining equipment and, thus, meet MSHA regulations.

Although the rib and degasification drills, and shotcrete machinery are standard tunneling equipment and conform to OSHA safety standards, they had to be slightly modified to include spark arrestors to conform with MSHA regulations. The hoists, being pneumatically powered, already meet the spark arrest regulations.

OSHA and MSHA safety regulations applicable to safe load limits, canopies (falling object protection), and design of high pressure vessels and lines are equivalent. Since all of the above equipment, is already in use, it readily conforms to these regulations. Consequently, when equipped with the modifications indicated in the preceding discussion, the tunnel borer system appears to be a sound design. This would be expected since the prototype design was completed.

\section{EVALUATION OF HEALTH AND SAFETY IMPROVEMENTS}

Having verified the regulatory integrity of the tunnel borer, the above analysis does not appear to indicate any inherent flaws requiring redesign. This finding represents the first positive design element of the system. The last positive design element stems from the ability of the design to mitigate the hazards listed in section III. There are many ways workers may be injured while performing various tasks. As some kinds of exposure may be more 
important than others, the design has a great effect on reducing exposure to hazards. In comparison with the continuous miner, the tunnel borer should demonstrate some design improvements in the hazard areas that presently contribute most to serious injuries. The results of the hazard analysis suggested that both systems experienced varying degrees of exposure to hazards associated with: (1) roof, face, or rib falls, (2) haulage, (3) machinery, (4) handling materials, (5) explosion and fire, (6) electricity, (7) slips and falls, (8) hand tools, and (9) pressure release. The first four of the general accident classes represent the major sources of serious injuries in contemporary underground mining, and therefore deserve the most attention when examining design improvements (2). There are also several health hazards associated with contemporary mining which must be addressed in evaluating a new design. The chief hazard centers around dust, and other carcinogenic, mutagenic, or toxic substances found in the mining environment (i.e., ammonia, other minerals deposited in the coal, and chemicals used while mining) (7). Other secondary hazards include: (1) temperature and humidity extremes which aggravate respiratory diseases such as bronchitis and asthma, (2) noise, (3) poor lighting, (4) cramped working space which adds to psychological stress, and (5) machinery vibration (7).

New concepts can reduce exposure to hazards by either reducing the time workers are exposed to hazards, or by providing more protection (13). Exposure time can be reduced through machinery redesign (i.e., machinery that performs a task more quickly so that workers are exposed to a given hazard for a shorter period of time), removal of hazardous tasks or machinery from the system, or decrease of the labor force exposed (2). Protection can be provided through machinery redesign (i.e., design equipment to provide a barrier against hazards), and provide monitoring devices to warn workers of impending hazards (2).

The Safety Methodology provided several examples of design improvements in all of the above areas as guidelines for determining the merit of a new system. In the first major hazard area, roof, face, or rib falls, the continuous miner system historically shows a high incidence of serious injuries related to: (1) operating the miner, bolter, and haulage in the face area, and (2) setting temporary support and testing the roof for instability. The tumilel borer affects both exposure time and protection through the following design characteristics which are in line with the proposed guidelines:

(1) Better roof stress distribution as a result of the circular entry design (increase in protection).

(2) Integration of the roof bolter with the miner to reduce the amount of time between excavation and bolting so as to reduce stress buildup in the strata (exposure time reduction and more protection).

(3) Location of permanent roof bolts $12 \mathrm{ft}$ from the face versus the present $20 \mathrm{ft}$ from the face (increase in protection).

(4) Application of shotcrete to the tunnel roof and walls to provide additional roof support and prevent entry weathering which causes sloughing (increase in protection). 
(5) Use of flexicore which provides an additional barrier against roof falls (increase in protection).

(6) Heavy-duty canopy protection for the roof bolters (increase in protection).

(7) Placment of the operator under a protective structure and remote operation of the miner (increase in protection).

(8) Elimination of the need to place temporary support at the face, except during maintenance (exposure time reduction).

The haulage accident class historically demonstrates a high incidence of injuries related to workers being struck by shuttle cars, being pinched between the machine and rib while the machine is maneuvering in the face area, and being struck or caught by the conveyor. One of the proposed design improvements to reduce these hazards is to provide adequate working and maintenance space around equipment. The tunnel borer design responds favorably to this guideline by:

(1) Eliminating the need for shuttle cars (exposure time reduction).

(2) Placing the conveyor overhead and away from the working area (exposure time reduction and more protection).

(3) Laying out the equipment in a straight line in order that the conveyor and track haulage do not interfere with other equipment and cannot change position or route; thus, workers always know where the haulage equipment is (increase in protection).

The largest portion of serious machinery injuries is attributed to workers being struck by machinery in the process of operating, moving or tramming equipment, at the face. This is primarily because of: (1) the high degree of mobility of equipment such as continuous miners and roof bolters, (2) the difficulty of controlling this equipment when it strikes hard partings in the coal, and (3) poor lighting. The tunnel borer system responds to these problems in the following manner:

(1) Workers are provided better lighting in the work areas (increase in protection).

(2) The roof bolter is integrated with the miner and constrained in its movement, therefore removing the need. to change and maneuver machinery in the face area (exposure time reduction and more protection).

(3) Workers are generally removed from the miner while it is operating (increase in protection).

(4) The miner is more stable and moves very slowly (increase in protection).

Serious injuries related to handling material have historically centered around workers handling objects which, by their weight or size, exceed a 
worker's physical capabilities. One important design guideline provided in this area is the incorporation of appropriate support equipment to assist in the handling and positioning of cumbersome objects. The tunnel borer conforms to this guideline by providing hoists to help move and position beam, pipe, track, and flexicore. This is clearly a protective feature. last areas where the tunnel borer offers design improvements are explosion, electrical, and slip and fall hazards. Historically, these accident classes have been aggravated by: (1) gas intrusion and buildup in the face area, (2) workers handling energized cables, and (3) poor lighting and poor footing. The tunnel borer reduces exposure to hazards associated with these accident classes through the following respective features:

(1) Degasification of the coal seam in advance of the miner (increase in protection).

(2) Lower cutter head speed to prevent sparking (increase in protection).

(3) Layout of equipment so that workers do not have to worry about constantly moving electrical cables out of the way of other equipment (exposure time reduction).

(4) Placement of the main power cable in a safe location away from most moving equipment and the working areas (increase in protection).

(5) Improved lighting in all the work areas (increase in protection).

Design features that offset health hazards are examined in the same fashion as the safety attributes (7). The four major ways of mitigating health hazards are through: (1) remote operation (workers do not come in contact with hazards); (2) system redundancy (the system has several ways of controlling a hazard, or the system continues operating and workers interface with the system only when the environment is cleared of dust, etc.); (3) fail safe, or early hazard detection devices (workers are apprised of a hazard well before allowable exposure levels are exceeded); and (4) protection (workers work in an unhealthy environment but are provided protection which offsets hazards) (7). In the case of the primary hazards of dust and other mutagenic or toxigenic substances, the tunnel borer system has both positive and negative characteristics. Better control of dust is accomplished through the following:

(1) A high ventilation rate at the face.

(2) Water sprays at the face.

(3) A spalling cutting technique, which cuts larger fragments and reduces airborne dust.

A negative characteristic is the use of shotcrete, which employs both cement and a toxic epoxy hardener. Because no control technology is employed to offset the airborne dust and hardener, workers can inhale these mutagenic and toxic substances. 
Other design improvements offered by the tunnel borer center around lighting and working space. As stated in Section II, the tunne'l borer uses a large number of 30-W fluorescent lights both on machinery and throughout the complete length of the tunnel. In addition, a minimum vertical clearance of ten feet between the floor and tunnel divider is provided. Though the immediate area around the flexicore hoist and rail cars is slightly restricted, the space just forward of the hoist, including the operator's skid, provides substantial room for the crew.

The remaining health hazards related to temperature and humidity extremes, noise, and machine vibration are not mitigated by the tunnel borer system design to any greater extent than existing underground mining systems.

In summary, it appears that several health and safety aspects of the tunnel borer design have reasonable merit, and warrant further investigation. At the same time, the results of the hazard analysis and the design comparisons can not be overlooked. As shown in Sections II and III, the tunnel borer not only requires twice the crew size as the continuous miner, but also requires additional tasks and machinery not part of the continuous miner system. the question that must be answered in the quantitative phase, is whether the design attributes presented in the preceding discussion have sufficient impact on mitigating major hazards so as to offset the potentially higher exposure affixed to the larger number of workers, tasks, and machinery employed. 


\section{SECTION V}

\section{QUANTITATIVE SAFETY EVALUATION}

\section{A. OVERVIEW}

The quantitative safety evaluation is a projection of injuriès drawing on distinct exposure time data, risk populations, and the design improvements (and liabilities) surfaced in the previous section. The main thrust of this portion of the analysis is to project the fatality, disabling injury; and "... overall injury rates for the tunnel borer system, compare them with continuous miner rates, and with the safety requirements for advanced systems. To be considered an advanced system, the tunnel borer overall projected injury rate should not exceed 40 to 45 injuries per million manhours, and the disabling injury and fatality rates should not exceed 30 and 0.2 injuries per million manhours, respectively.

The component of the injury rate projection, dealing with the influence of exposure time, utilizes: (1) an exposure time index which is the ratio of tunnel borer task exposure time, to either continuous miner or tunneling industry task. exposure time, (2) the ratio of the respective populations at risk for a given task and hazard, and (3) the historical continuous miner and tunneling industry injuries associated with a given task and hazard ( 2 ). The historical injuries are multiplied by the exposure time index and the risk population ratio to determine the projected tunnel borer injury rate for the commensurate tasks and hazards (2).

The component of the injury rate projection dealing with the influence of bodily protection, involves a detailed examination of the protective device, followed by a subjective rating of the effect the protective measure will have on reducing injuries associated with the analogous conventional system. The new system must offer complete protection for the body areas that are most exposed and have the most severe injuries in order to be judged as a sound design (2). The ratings are respectively: (1) complete or fairly complete protection (a protective envelope is provided, thereby mitigating all or most hazards), (3) incomplete protection (those areas of the body which contribute most to serious injuries are still exposed a large part of the time), and (4) no protection (the new system offers protection less than or equal to existing systems, not mitigating hazards that contribute to existing injury levels at all).

Both exposure time and protection injury projections, as they apply to the various hazards and design elements, are presented to a group of experts in mining safety for the last aspect of the analysis. The experts are asked to adjust the injury rates in light of the exposure time and risk population data, degree of protection provided, and their own experience with how these parameters effect injuries. The adjusted projections are displayed as a range reflecting all the experts' inputs and represent the final projected injury rates for the tunnel borer system. 


\section{Injury Data}

The source of the bulk of the historical data used in the analysis is the MSHA Report CM 341L2, (Injury by Worker Activity) (5). To get a reasonable sample of characteristic injuries associated with continuous mining, four years of data (1976 through 1979) were averaged. In many cases, distinct injuries related to continuous miner activities were specifed in the various accident classes. For those activities typical of contemporary mining practice, but not specifically identified with continuous mining, the average percent contribution of continuous mining to total yearly underground mining injuries (i.e., 60\%) was used following the suggestion provided in the safety evaluation procedure ( 2 ).

Tunneling industry injury data were used for the hoist, degasification and rib drill, and shotcrete elements of the tunnel borer system. These historical injury data were obtained from the Bureau of Reclamation in Denver, Colorado (12). Again, a representative baseline for injury levels associated with the above equipment was obtained by averaging the data for 1976 through 1979 .

\section{Task Time Data}

Worker activities for both the tunnel borer and continuous miner systems were described during the discussion of system operation and worker interactions with hazards. Reductions in the time that workers are exposed to hazards, while operating and maintaining machinery or performing support tasks such as cleanup or ground control, are essential to improved injury performance. For example, the ideal situation would be to remove a worker from hazardous tasks via automation or remote operation, causing the exposure time to drop to zero. Since the tunnel borer system is not an automated system, an evaluation of the exposure time is more complex. The qualitative evaluation suggested that workers could potentially experience both reductions and increases in exposure time compared with continuous mining, therefore requiring a more detailed task time analysis to assess ággregate exposure. In suppport of this assessment, task time data for the tunnel borer system were obtained from the Bureau of Mines industrial engineering studies performed during system design (6). Some additional task and maintenance time data were also obtained during operation of the prototype. These studies established task schedules and manpower requirements for a normal 8-h hour shift. The major tasks included, (1) tunnel borer operating time (2) roof bolting time, (3) rail track assembly time, (4) track laying time, (5) water pipe installation time, (6) beam installation time, (7) beam punching time, flexicore installation time, (9) cleanup time, (10) shotcreting time, degasifications time, (12) rail car operating time, and (13) conveyor operating time. Generally speaking, detailed machine maintenance data were not available from the industrial engineering studies or observation of the prototype. Machine maintenance times typical of each of the equipment components were obtained through discussion with one of the machine users, and the two machine manufacturers $(9,10,11)$. Task times for the equivalent continuous miner tasks, listed in Appendix A of the safety evaluation procedure, were extracted from an industrial engineering study of continuous 
mining, performed by J. J. Davis Associates (2, 14). Table 5-1 displays the task times for both the tunnel borer and continuous miner systems. Where there is no continuous miner task analogous to the tunnel borer, the relevant tunneling industry task is used (e.g., shotcreting).

Examination of Table 5-1 shows that in many cases. (such as operating the miner, conveyor, rail cars or trolley, hoists, large drills, and shotcrete machinery) the exposure is approximately the same for both systems. Similarly the exposure is equivalent for certain maintenance and support tasks. This finding is reasonable because both systems employ state-of-the-art machinery and therefore require similar maintenance and support activities. Exposure reductions for the tunnel borer are clearly evident because the shuttle car operation, cable reeling and handling, and temporary support activities are removed or greatly reduced. Increases in exposure are related to the roof bolting, cleanup, and handling material activities. As expected, exposure times associated with cleanup and handling material activities are considerably higher than the continuous miner. Exposure during roof bolting is higher because of the integrated miner-bolter design. This design eliminates the tramming and positioning time associated with the conventional roof bolter and allows more actual bolting time.

The exposure indices are formed by taking the ratio of the tunnel borer task time to the continuous miner (or tunneling) task time. Often the exposure index is formed from the direct ratio of singular tasks in Table 5-1: However, in order to have the worker interactions and hazards identified in the tunnel borer hazard analysis conform with the way the MSHA injury data are reported for the equivalent continuous miner worker activities and hazards, it is sometimes necessary to form the exposure index from groups of tasks, or from components of the tasks 1 isted in Table 5-1.

\section{Manpower Data}

The manpower requirements for both systems are summarized in Section II-D. As in the case of the task time analysis, detailed manpower requirements were extracted from the same industrial engineering studies and tunneling industry experience $(6,9,10,11,14)$. Table 5-2 displays the respective detailed manpower allocations as a function of the same basic tasks provided in Table 5-1.

Table 5-2 confirms the conclusion drawn earlier in Section II, namely, that the tunnel borer is considerably more labor-intensive than the continuous miner system. Significant differences are evident in the shotcreting and bull gang crew sizes. These two crews are a factor of 3 to 5 greater than the total number of people employed in similar continuous miner tasks. Note that though the continuous miner and tunnel borer systems employ a hub of 11 or 12 , and 22 workers respectively, many workers perform multiple tasks. Therefore, as workers move from one work area to another, they can be exposed to different hazards. This is considered later during the injury projection phase. 
Table 5-1. Exposure Time Comparison between the Tunnel Borer. and Continuous Miner Systems

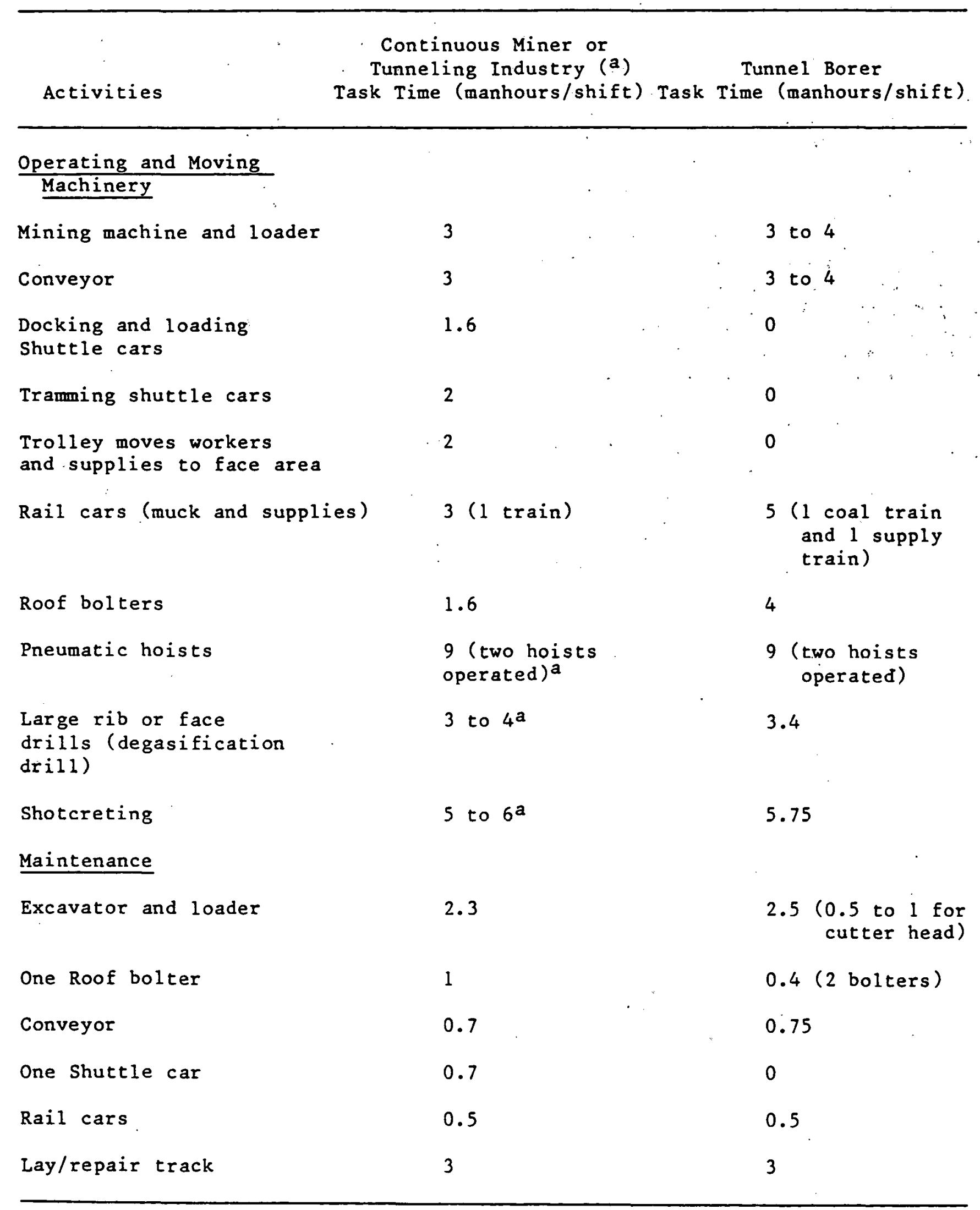


Table 5-1. (Cont'd)

Continuous Miner or

Tunneling Industry (a)

Task Time (manhrs/shift)
Tunnel Borer

Task Time (manhrs/shift)

\begin{tabular}{llc} 
Pneumatic hoists & $0.5^{\mathrm{a}}$ & 0.5 \\
Degasification/rib drills & $0.7-0.8^{\mathrm{a}}$ & 0.75 \\
Shotcrete machinery & $1 \mathrm{a}$ & 1 \\
Weld repairs on machinery & 0.8 & 0.8 \\
Support Activities & & \\
\hline $\begin{array}{l}\text { Environmental checks of gas } \\
\text { and dust levels }\end{array}$ & 0.25 & \\
Setting brattice & & \\
Cleanup around machinery & 0.5 & \\
- Excavator & & \\
- Loader or loading hopper & 0.4 & \\
- Conveyor & 0.5 & 0.25 \\
- Shotcrete rebound and & 0.5 & 0.25 \\
\end{tabular}

Cable reeling \& moving for the

- miner

1.4

0

- haulage

1.7

0

- roof bolter

0.1

0

Setting temporary support,

5.2

0.3 (mostly barring

testing and marking the roof, down lonse material)

Handling and moving materials

6

11.8

such as temporary support,

beams, timber, brattice, stop-

pings, track, gob, roof bolts,

pipe, flexicore, etc.

Outby support activities

4

1

such as replacing old

cribbing and rebuilding

stoppings,barring down rib

slough, drilling and punch-

ing beams, storing supplies, etc.

Supervision by foreman

5.6

5.6 
Table 5-2. Detailed Manpower Comparison Between the Tunnel Borer and - Continuous Miner Systems

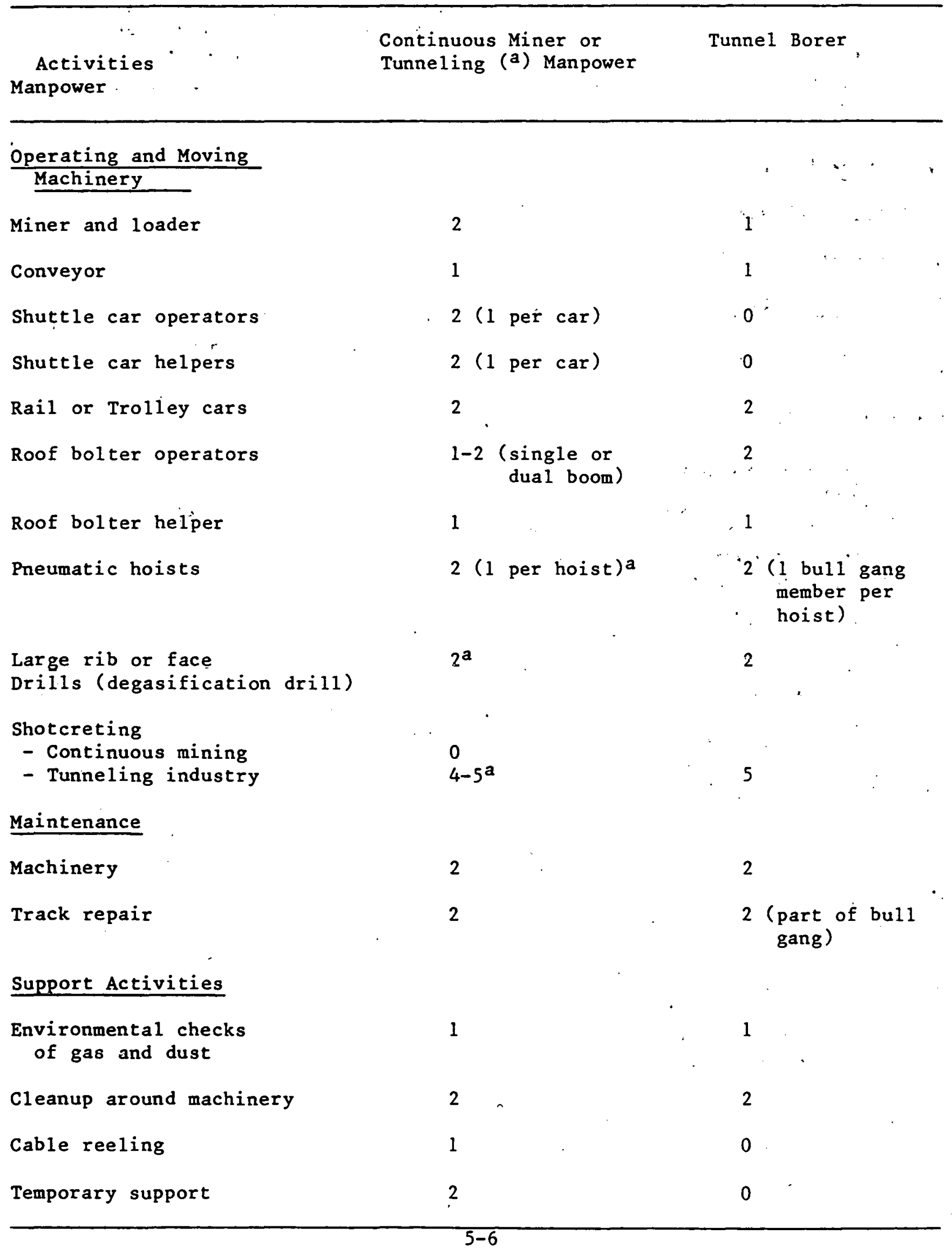


Table 5-2. (Cont'd)

\begin{abstract}
Activities
Manpower

Setting brattice

Handling materials such as

temporary support, beams,

timber, track, pipe, flexicore,

etc.
\end{abstract}

Continuous Miner or

Tunneling (a) Manpower
Tunnel Borer
Outby support activities

Supervision or cleanup team)

2-3 (temporary support team and cleanup team)
2 (temporary support

0

5 (bull gang)

4-5

2 (part of bull gang)

4. Subjective Ratings of Protective Measures

Several types of protective measures were identified in the qualitative evaluation. In addition, the ratings for various protective measures were provided in the preceding overview. These ratings range from "complete protection" to "no protection", in recognition of the degree of protection afforded those areas of the body which historically experience the most serious injuries (2). The areas of the body most affected by roof, rib, or face falls are the head, trunk, arms and hands, and lower extremities. In contemporary haulage accidents, the trunk is affected the most, followed by the arms, hands and head. These are typically pinch and squeeze type injuries. Serious machinery injuries have the greatest effect on the arms and hands, followed by the trunk and lower extremities. These injuries generally involve being caught or struck by machinery. In handling material accidents, the arms and hands typically receive the most serious injuries, followed by injuries to the trunk and lower extremities. Severe injuries in this accident class are primarily the result of dropping materials, or being struck or pinched while moving or positioning components. Electrical injuries, primarily a result of arcing and shock during maintenance activities, usually affect the eyes, arms, and hands. In slips and falls, the lower extremities suffer the greatest amount of injuries, followed by the trunk, arms, and hands. Explosion and fire injuries have the most severe effect on the head, and to a lesser extent, the trunk, arms, and hands. Pressure bursts are often encountered while performing maintenance and, thus, affect the eyes and head the most, followed by the trunk, arms, and hands. As stated in the overview, a protective measure must provide a complete protective envelope to be considered totally effective. If a new design succeeds in establishing a procective barrier aruund the worker, exposure time is no longer an issue. However, protection judged as anything less than complete implies that workers 
are still exposed to hazards in varying degrees. In these cases, exposure time increases could offset any protection offered and must subsequently be carefully considered in any projections. Trade-offs between protection and exposure time, as they affect injury rates, are considered during the injury adjustment process performed by the group of experts. Table 5-3 provides the author's initial effectiveness ratings based on a closer scrutiny of the protective measures identified in the qualitative evaluation.

a. Protection Against Rock Falls. Those design features that provide "complete protection" are readily apparent because either there is a substantial barrier between the worker and hazard, or the design allows for the task to be accomplished remotely. The other ratings are not as clear-cut. In the case of the roof fall hazard associated with the roof bolters, a "fairly complete" rating was given because the heavy-duty canopy grating would protect the head, trunk, and lower extremities; but not the arms and hands. Workers would still have their arms and hands exposed in the gap in the grating, which allows the roof bolters to slide on their tracks. This gap provides room for changing drill bits, inserting bolts, or barring down loose rock. An "incomplete" rating was assigned to protection against falls of ground while engaged in maintenance because: (1) workers would have their arms and hands exposed while maintaining the roof bolters, and (2) workers would have all key body areas exposed while working in the face area on the cutterhead and the support jacks. A "fairly complete" rating was assigned to protection against cleanup hazards because the borer itself would provide protection while cleaning up under the machine. The only exception would apply to cleaning up around the side thrust jacks.

b. Protection Against Haulage and Other Machinery Hazards. In the haulage accident class, workers drilling the rib for beam installation run a small risk of being struck by muck cars, or rail cars bringing in oupplies. Under most conditions, the layout of the equipment places the drilling activity well ahead the rail car operation, thus providing fairly complete protection.

A "fairly complete" rating was assigned to protection against machinery hazards pertinent to workers being struck doing cleanup because the design allows workers to generally stay out of the way of the tunnel borer. The roof bolter configuraton was judged as providing "fairly complete" protection because only the arms and hands are left exposed to minor injury.

The hoists used for moving and positioning the beams, pipe, track and flexicore were rated as "incomplete" because of all the manual handing still required while attaching hoist cables and installing the components. Consequently, all the body components which suffer the most severe injuries are still exposed during the bulk of the task time.

$$
\text { c. Protection Against Explosion, Electrical, and Other }
$$

Hazards. The protective measures which offset the explosion and electrical hazards associated with moving equipment, were considered "fairly complete" because workers are provided protection for the key body areas most of the time. However, these measures do not set up a complete protective envelope 


\begin{tabular}{|c|c|c|c|}
\hline Accident Class/Hazard & & $\begin{array}{l}\text { Protective } \\
\text { Measures }\end{array}$ & $\begin{array}{l}\text { Initial } \\
\text { Effectiveness } \\
\text { Rating }\end{array}$ \\
\hline Roof/face/rib falls & & & . \\
\hline $\begin{array}{l}\text { Struck while operating } \\
\text { excavator } \\
\text {. }\end{array}$ & $\begin{array}{l}0 \\
0 \\
0 \\
0 \\
0\end{array}$ & $\begin{array}{l}\text { Remote operation } \\
\text { Roof bolts } \\
\text { Shotcrete } \\
\text { Circular entry design } \\
\text { Canopy on control } \\
\text { room skid }\end{array}$ & Complete \\
\hline $\begin{array}{l}\text { Struck while operating } \\
\text { roof bolter }\end{array}$ & 0 & $\begin{array}{l}\text { Heavy-duty canopy } \\
\text { completely encloses } \\
\text { bolting stations } \\
\text { Permanent support placed } \\
\text { immediately and closer } \\
\text { to face }\end{array}$ & Fairly complete \\
\hline $\begin{array}{l}\text { Struck while operating } \\
\text { haulage in face area }\end{array}$ & $\begin{array}{l}\circ \\
0 \\
0 \\
0\end{array}$ & $\begin{array}{l}\text { Conveyor is remotely } \\
\text { operated and monitored } \\
\text { from control room skid } \\
\text { Roof bolts } \\
\text { Shotcrete } \\
\text { Circular entry design }\end{array}$ & Complete \\
\hline $\begin{array}{l}\text { Struck while operating rail } \\
\text { cars or riding equipment }\end{array}$ & $\begin{array}{l}0 \\
0 \\
0 \\
0\end{array}$ & $\begin{array}{l}\text { Shotcrete } \\
\text { Circular entry design } \\
\text { Roof bolts } \\
\text { Flexicore panels }\end{array}$ & Complete \\
\hline $\begin{array}{l}\text { Struck while performing } \\
\text { maintenance on equipment }\end{array}$ & $\begin{array}{l}0 \\
0 \\
0 \\
0 \\
0\end{array}$ & $\begin{array}{l}\text { Shotcrete } \\
\text { Circular entry design } \\
\text { Roof bolts } \\
\text { Flexicore panels } \\
\text { Canopies on skids }\end{array}$ & Incomplete \\
\hline $\begin{array}{l}\text { Struck while performing } \\
\text { environmental checks } \\
\text { in-between equipment moves }\end{array}$ & $\circ$ & $\begin{array}{l}\text { Continuous gas monitoring } \\
\text { mounted on boring machine }\end{array}$ & Complete \\
\hline $\begin{array}{l}\text { Struck while performing clean- } \\
\text { up around excavator and } \\
\text { conveyor }\end{array}$ & $\begin{array}{l}0 \\
0\end{array}$ & $\begin{array}{l}\text { Circular entry design } \\
\text { Roof bolts located closer } \\
\text { to face }\end{array}$ & Fairly complete \\
\hline
\end{tabular}


Table 5-3. (Cont'd)

\begin{tabular}{ccc} 
& & Initial \\
Accident class/Hazard & $\begin{array}{l}\text { Protective } \\
\text { Measures }\end{array}$ & $\begin{array}{c}\text { Effectiveness } \\
\text { Rating }\end{array}$ \\
\hline
\end{tabular}

\section{Haulage}

Struck while operating or articulating conveyor

- Conveyor mounted overhead, Complete away from work areas

struck while drilling face or rib

- Equipment layout

Fairly complete

Struck while performing cleanup or maintenance in area of. operating conveyor

- Conveyor is not articulated and not subject to rapid lateral movement

Incomplete

\section{Machinery}

Operator or helper struck, or pinched between rib and machine, while operating miner

Worker struck while doing cleanup around machinery - Remote operation of Complete
miner

- Tunnel borer constrained Fairly complete to move in one direction and is not subject to rapid movements

0 . Machinery layout does not allow for other machinery to be in same working area

- Improved lighting

Workers struck while tramming and operating roof bolters

- Roof bolters integrated Fairly complete with boring machine

- Roof bolters constrained. to slide on track

Workers struck by other equipment in area of bridge conveyor

- Conveyor located overhead away from other machinery

Complete

Handling Materials

Workers struck or pinched while handling supplies, or laying and repairing track

- Hoists provided to assist Incomplete in moving and positioning components 
Table 5-3. (Cont'd)

\section{Accident Class/Hazard}

Protective

Measures

Initial

Effectiveness

Rating

Explosion

Workers burned, or struck

by flying debris, due to

ignition of methane gas in

face area
- Degasification of coal.
- Slower cutting head rate reduces sparking
- Shotcrete lining and ventilation

Fairly complete

\section{Electrical}

Workers are tramming. or moving equipment and contact frayed cable

Workers performing cleanup, or handling conducting materials, and contact frayed cable

\section{Slip and Fall}

Workers slip and fall while guiding excavator or conveyor during pooition change

Workers slip and fall while performing cleanup, maintenance, or handling materials
- Cable hung on rib and removed from working areas

- Equipment layout

- Cable hung on rib, away from working areas

- Equipment layout

- Miner remotely operated Complete

- Conveyor out of working area

- More adequate lighting
Incomplete

Fairly complete

Incomplete

around workers. The hazard associated with contacting a frayed cable during cleanup, or handling materials, was regarded as being only marginally affected by the protective measures. This was because all of the key body areas would be exposed to a cable damaged by shotcrete blast or a swinging beam, or severed while cleaning up rebound. Similarly, the added protection against slips and falls provided by the improved lighting was judged "incomplete". This rating stemmed from workers experiencing an increase in exposure during the extensive handling material tasks. These hazards are aggravated by elevated work stations and obstacles on the tunnel floor, all of which contribute to falls and ocrious injury. 
With the required data now in hand, it is possible to proceed with the injury projections. At this time it is appropriate to review the formula and variables as they appear in the safety evaluation procedure (2):

$$
n_{i}=N_{i} t_{i} / T_{i} \quad f_{i} g_{i}
$$

where

$$
\begin{aligned}
\mathrm{n}_{\mathrm{i}}= & \text { the projected injuries for a given task } i \text { and hazard in the } \\
& \text { new system (injuries/yr). } \\
\mathrm{N}_{\mathrm{i}}= & \text { the total number of injuries associated with a given task } \mathrm{l} \\
& \text { and hazard of the contemporary system used as a comparison } \\
& \text { (injuries/yr). } \\
\mathrm{t}_{\mathrm{i}} / \mathrm{T}_{\mathrm{i}}= & \text { the measure of the fractional change in task exposure time } \\
& \text { between the new ( } \mathrm{t}_{\mathrm{i}} \text { ) and contemporary comparison }\left(\mathrm{T}_{\mathrm{i}}\right) \\
& \text { systems (dimensionless). } \\
\mathrm{f}_{\mathrm{i}}= & \text { the manpower ratio for a.given task } \mathrm{i} \text { and hazard.of .the new } \\
& \text { and contemporary comparison systems (dimensionless). } \\
g_{i}= & \text { the injury adjustment factor, which reflects the consensus of } \\
& \text { the group of experts pertaining to the safety integrity of the } \\
& \text { new system (expressed as a fractional change in injuries). }
\end{aligned}
$$

Because expert judgment is not incorporated until the end of the analysis, the initial projection is made with a value of unity assigned to the expert adjustment factor. The same variable related to protective measures is assigned qualitative values of large, medium, or small, relative to the projected affect on reducing injuries. Later, during the consultation with experts, this variable is given a numerical value. The expression for consideration of protective aspects of a new design is as follows:

$$
\mathrm{b}_{\mathrm{j}} \quad=\quad \mathrm{B}_{\mathrm{j}} \mathrm{d}_{\mathrm{j}}
$$

where

$b_{j}=$ the injury projection considering the incorporation of new protective design measures for a given hazard and accident class. $j$ (injuries/yr).

$B_{j}=$ the aggregate number of historical injuries to the body (or the initial exposure time injury projection) for a given hazard and accident class (injuries/yr).

$d_{j}=$ the general consensus of the group of experts pertaining to the integrity of the new protective device (expressed as a fractional change in injuries).

The above definition of $B_{j}$ indicates that the initial exposure time injury projection can also be represented by this term. This substitution can occur 
if the initial injury projection is affected by both an exposure time reduction and an increase in protection, in which case the protection can cause a further decrease in injuries.

The injury projection is made for yearly fatalities (F), disabling injuries (DI), and nondisabling injuries (NDI). The initial injury projection, excluding the input from the experts, reflects both exposure time and protection aspects. For example, if a given activity/hazard combination experiences both an exposure time reduction and a fairly complete protective measure, then the projection would reflect a reduced injury level due to the numerically smaller exposure index, and have a "less than" term associated with it to reflect the additional injury reduction expected from the protective device. In the case of complete protection, exposure time does not enter the picture and a "much less than" term is assigned to the injury projection. An "incomplete" rating on a protective measure has no affect on the projected injuries. The following example demonstrates the basic numerical process. The hazard of being struck by a rock fall while testing or barring down roof, and roof bolting is a good example of both an exposure time reduction and protection improvement. The exposure time ratio, applying the task times from Table 5-1, is calculated as follows:

- The time spent roof bolting, setting temporary support, marking the roof, and barring down loose rock for continuous mining is the total of 1.6 and 5.2 manhours per shift, respectively; or, 6.8 total manhours per shift.

- The time spent roof bolting and barring down loose rock for the tunnel borer is 4 and 0.3 manhours per shift, respectively; or, 4.3 total manhours per shift.

- The task time ratio is then $4.3 / 6.8$, or 0.6 .

The manpower ratio is unity since manning levels are the same. The projection for disabling injuries would be as follows:

$$
n_{i}=N_{i} t_{i} / T_{i} \quad f_{i} g_{i}
$$

where

$$
\begin{aligned}
\mathrm{N}_{i} & =309 \text { injuries/yr } \\
\mathrm{t}_{\mathbf{i}} / \mathrm{T}_{\mathbf{i}} & =0.6 \\
\mathrm{f}_{\mathbf{i}} & =1 \\
\mathrm{~g}_{\mathbf{i}} & =1
\end{aligned}
$$

then

$$
\begin{aligned}
& n_{i}=(309)(0.6)(1)(1) \\
& n_{i}=185 \text { disabling injuries/yr }
\end{aligned}
$$


The protective canopy was rated as "fairly complete", so the above injury projection would be stated as "less than 185 disabling injuries".

This projection technique examines hazard/activity combinations in sufficient depth to separate the high and low contributors to injuries. Because the primary concern is to eliminate major hazards, the following tables thus display projections for the hazards that account for the largest portion of the total injuries in each accident class. More detailed injury and hazard data are given in Appendix A. Where protective measures do not enter in the projection, the term "not applicable" (N/A) is placed in the table column which indicates the effect of the protection.

\section{Roof, Face, and Rib Fall Injuries}

Table 5-4 shows that the tunnel borer demonstrates the greatest improvement in the area of setting temporary support and roof bolting. Although more time is spent bolting, the hazardous task of setting temporary support is totally eliminated. Additionally, the protection provided the bolters further offsets injuries. The exposure time reduction related to the maintenance hazard stems from exposing workers only while working on the cutter head and first stage conveyor. All other maintenance is done under complete protection. Operation of the tunnel borer is removed from the face in a completely protected location. The cleanup activity in the immediate face area requires less time and is also done under the protection of the boring machine most of the time. Another major improvement is in the elimination of manned haulage from the face area.

\section{Haulage Injuries}

The major improvements indicated in Table 5-5 revolve around the elimination of the loader and shuttle cars. Other hazards that contribute significantly to haulage injuries are derailments, rerailing cars, or being struck while getting on and off cars. However, the tunnel borer system offers no improvements in any of these areas.

\section{Machinery Injuries}

The machinery improvements shown in Table 5-6 have a more complex impact on injuries than those associated with haulage or rock falls. The hazards associated with these improvements are: (1) being struck while doing cleanup, and (2) being struck while roof bolting. In both cases the tunnel borer increases exposure time, while offering additional protection at the same time. The net effect is an expected injury level less than the injury increase projected. The actual effect of the protection will be determined after examination by the experts. One of the more obvious impacts of the. tunnel borer revolve around the improvement in protection for the excavator operator, therefore largely mitigating the hazard of being struck while operating the miner. At the same time, there is a projected increase in total injuries due to the additional tunneling equipment. Whether these design improvements will offset the additional injuries caused by the tunneling equipment will depend on the final subsequent analysis by experts. 
Table 5-4. Initial Injury Projection for Roof, Face, and Rib Falls

\begin{tabular}{|c|c|c|c|c|c|}
\hline Hazard/Activity & $\begin{array}{l}\text { Task } \\
\text { Time } \\
\text { Ratio }\end{array}$ & $\begin{array}{l}\text { Labor } \\
\text { Ratio }\end{array}$ & $\begin{array}{l}\text { Effect of } \\
\text { Protection }\end{array}$ & $\begin{array}{l}\text { Hist. } \\
\text { Inj } \\
(\mathrm{F} / \mathrm{DI} / \mathrm{NDI})\end{array}$ & $\begin{array}{l}\text { Proj. } \\
\text { Inj } . \\
\text { (F/DI/NDI) }\end{array}$ \\
\hline $\begin{array}{l}\text { Struck while } \\
\text { operating miner }\end{array}$ & \multicolumn{2}{|c|}{$\begin{array}{l}\text { Protective } \\
\text { measure }\end{array}$} & Large & $3 / 42 / 14$ & $\begin{array}{l}\text { Much less } \\
\text { than } \\
3 / 42 / 14\end{array}$ \\
\hline $\begin{array}{l}\text { Struck while per- } \\
\text { forming maintenance }\end{array}$ & 0.35 & 1 & Small & $1 / 36 / 8$ & $0 / 13 / 4$ \\
\hline $\begin{array}{l}\text { Struck while per- } \\
\text { forming cleanup }\end{array}$ & 0.6 & 1 & Medium & $2 / 70 / 13$ & $\begin{array}{l}\text { Less than } \\
1 / 42 / 8\end{array}$ \\
\hline $\begin{array}{l}\text { Struck while test- } \\
\text { ing roof, barring } \\
\text { down, and roof bolt- } \\
\text { ing }\end{array}$ & 0.6 & 1 & Medium & $14 / 309 / 129$ & $\begin{array}{l}\text { Less than } \\
8 / 185 / 77\end{array}$ \\
\hline $\begin{array}{l}\text { Struck while opera- } \\
\text { ting haulage in } \\
\text { face area }\end{array}$ & $\begin{array}{l}\text { Prote } \\
\text { measu }\end{array}$ & $\begin{array}{l}\text { tive } \\
\text { e }\end{array}$ & Large & $1 / 28 / 9$ & $\begin{array}{l}\text { Much less } \\
\text { than } 1 / 28 / 9\end{array}$ \\
\hline
\end{tabular}

\section{Handling Material Injuries}

The projections given in Table 5-7 show that the three major sources of handling material injuries (machine maintenance, cleanup, and supply) are seriously aggravated in the tunnel borer system. As indicated earlier, these safety problems are caused by the greater amount of machinery, shotcrete rebound problem, and the nature of the beam and flexicore activities. The one area where the tunnel borer demonstrates an improvement is the elimination of the cable handling tasks associated with the continuous miner.

\section{Explosion and Fire Injuries}

The major hazards associated with explosions and fires basically involve those activities performed near the face area. These are the operation and maintenance tasks related to the excavator and roof bolters. Table 5-8 shows that the protection offered by degasification, the shotcrete lining, and reduced cutter head speed is "fairly complete" for operating and roof bolting; however, it is considered only marginal for maintenance due to the fire hazard created by leaking hydraulic fluid. 
Table 5-5. Haulage Injury Projection

\begin{tabular}{|c|c|c|c|c|c|}
\hline Hazard/Activity & $\begin{array}{l}\text { Task } \\
\text { Time } \\
\text { Ratio }\end{array}$ & $\begin{array}{l}\text { Labor } \\
\text { Ratio }\end{array}$ & $\begin{array}{l}\text { Effect of } \\
\text { Protection }\end{array}$ & $\begin{array}{l}\text { Hist. } \\
\text { Inj } \\
\text { (F/DI/NDI) }\end{array}$ & $\begin{array}{l}\text { Proj. } \\
\text { Inj } \\
(\mathrm{F} / \mathrm{DI} / \mathrm{NDI})\end{array}$ \\
\hline $\begin{array}{l}\text { Operator or helper } \\
\text { caught or struck by } \\
\text { loader }\end{array}$ & 0 & 0 & N/A & $3 / 94 / 26$ & $0 / 0 / 0$ \\
\hline $\begin{array}{l}\text { Operator or workers } \\
\text { pinched or struck by } \\
\text { shuttle car }\end{array}$ & 0 & 0 & N/A & $1 / 174 / 3$ & $0 / 0 / 0$ \\
\hline $\begin{array}{l}\text { Pinched while rerail- } \\
\text { ing cars, or operator } \\
\text { pinched in derailment }\end{array}$ & 1 & 1 & N/A & $1 / 108 / 42$ & $1 / 108 / 42$ \\
\hline $\begin{array}{l}\text { Pinched or struck } \\
\text { getting on or off } \\
\text { equipment, or riding } \\
\text { equipment }\end{array}$ & 1 & 1 & N/A & $2 / 222 / 66$ & $2 / 222 / 66$ \\
\hline
\end{tabular}

\section{Electrical Injuries}

By far the worst hazard encountered in the electrical area is the handing-of electrical components and power cables during maintenance or cleanup activities. Table 5-9 shows that while the elimination of the cable handling tasks reduces exposure in this area, an increase in exposure occurs due to the greater maintenance and cleanup required by the tunnel borer system. A decrease in injuries was projected for the hazard caused by moving equipment contacting energized cables, since the power cables are removed from the working areas and placed in relatively undisturbed locations.

\section{Slip and Fall Injuries}

Table 5-10 displays a projected increase in slip and fall injuries. in three of the five major hazard categories and, no change for the remaining categories. The increase projected for maintenance was based on a greater exposure time. Here, improved lighting was considered ineffectual because it was felt that workers would be exposed to more injuries falling from elevated locations while doing maintenance on the tunnel borer, hoists, and degasification drill. The size and weight of the beams and flexicore, together with increased exposure during cleanup, offset the advantage of better lighting in these hazard areas. The hazards areas associated with rail car operation and supervision exposed workers to the same degree as in the continuous miner system, resulting in no projected improvement. 
Table 5-6. Initial Injury Projection for Machinery Hazards

\begin{tabular}{|c|c|c|c|c|c|}
\hline Hazard/Activity & $\begin{array}{l}\text { Task } \\
\text { Time } \\
\text { Ratio }\end{array}$ & $\begin{array}{l}\text { Labor } \\
\text { Ratio }\end{array}$ & $\begin{array}{l}\text { Effect of } \\
\text { Protection }\end{array}$ & $\begin{array}{l}\text { Hist. } \\
\text { Inj } . \\
(F / D I / N D I)\end{array}$ & $\begin{array}{l}\text { Proj. } \\
\text { Inj } \\
\text { (F/DI/NDI) }\end{array}$ \\
\hline $\begin{array}{l}\text { Operator or helper } \\
\text { struck while opera- } \\
\text { ting miner }\end{array}$ & \multicolumn{2}{|c|}{$\begin{array}{l}\text { Protective } \\
\text { measure }\end{array}$} & Large & $0 / 94 / 34$ & $\begin{array}{l}\text { Much less } \\
\text { than } \\
0 / 94 / 34\end{array}$ \\
\hline $\begin{array}{l}\text { Struck while doing } \\
\text { Cleanup }\end{array}$ & 4 & 1 & Medium & $0 / 38 / 20$ & $\begin{array}{l}\text { Less than } \\
0 / 152 / 80\end{array}$ \\
\hline $\begin{array}{l}\text { Struck while moving } \\
\text { or operating roof } \\
\text { bolters }\end{array}$ & 2.5 & 1 & Medium & $1 / 516 / 175$ & $\begin{array}{l}\text { Less than } \\
.3 / 1290 / 438\end{array}$ \\
\hline $\begin{array}{l}\text { Struck or caught } \\
\text { while moving or } \\
\text { operating large drills } \\
\text { (Tunneling experience) }\end{array}$ & 1 & 1 & $\mathbf{N} / \mathbf{A}$ & $0 / 8 / 3^{a}$ & $0 / 8 / 3$ \\
\hline $\begin{array}{l}\text { Caught while opera- } \\
\text { ting or unclogging } \\
\text { shotcrete machinery } \\
\text { (Tunneling experience) }\end{array}$ & 1 & 1 & $\mathbf{N} / \mathbf{A}$ & $0 / 5 / 14^{a}$ & $0 / 5 / 14$ \\
\hline $\begin{array}{l}\text { Caught while main- } \\
\text { taining shotcrete } \\
\text { machinery } \\
\text { (Tunneling experience) }\end{array}$ & 1 & 1 & N/A & $0 / 3 / 1^{a}$ & $0 / 3 / 1$ \\
\hline $\begin{array}{l}\text { Struck or caught } \\
\text { while uperating } \\
\text { hoists } \\
\text { (Tunneling experience) }\end{array}$ & 1 & 1 & N/A & $0 / 2 / 1^{a}$ & $0 / 2 / 1$ \\
\hline
\end{tabular}

anjuries per million manhours.

8. Hand-tool Injuries

Table 5-11 essentially reflects the effects of more manhours and a larger workforce on hand-tool injuries. In the case of maintenance, workers are responsible for more machinery and therefore use hand tools more frequent1y. As the historical injury data segregate hand-tool injuries by maintenance, cleanup, setting temporary support, and repairing track, the hazard referenced as "hand tools slipping or breaking while being used" addresses other support activities in the continuous miner system. These activities include building 
Table 5-7. Initial Injury Projection for Handling Material Hazards

\begin{tabular}{llcccc}
\hline & $\begin{array}{l}\text { Task } \\
\text { Time } \\
\text { Ratio }\end{array}$ & $\begin{array}{c}\text { Labor } \\
\text { Ratio }\end{array}$ & $\begin{array}{c}\text { Effect of } \\
\text { Protection }\end{array}$ & $\begin{array}{c}\text { Hist. } \\
\text { Inj. } \\
\text { (F/DI/NDI) }\end{array}$ & $\begin{array}{c}\text { Proj } \\
\text { Inj } \\
\text { (F/DI/NDI) }\end{array}$ \\
\hline $\begin{array}{l}\text { Hazard/Activity } \\
\begin{array}{l}\text { Worker drops com- } \\
\text { ponent while doing } \\
\text { maintenance }\end{array}\end{array}$ & 1.2 & 1 & N/A & $0 / 256 / 141$ & $0 / 307 / 169$ \\
$\begin{array}{l}\text { Struck while handling } \\
\text { material during } \\
\text { cleanup : }\end{array}$ & 4 & 1 & N/A & $0 / 111 / 42$ & $0 / 444 / 168$ \\
$\begin{array}{l}\text { Pinched or struck } \\
\text { while handling } \\
\text { supplies }\end{array}$ & 2 & 2.6 & Small & $0 / 1244 / 365$ & $0 / 6469 / 1898$ \\
$\begin{array}{l}\text { Injured handling } \\
\text { power cables }\end{array}$ & 0 & 0 & N/A & $0 / 168 / 50$ & $0 / 0 / 0$ \\
\hline
\end{tabular}

Table 5-8. Initial Injury Projection for Explosion and Fire.Hazards

\begin{tabular}{|c|c|c|c|c|c|}
\hline Hazard/Activity & $\begin{array}{l}\text { Task } \\
\text { Time } \\
\text { Ratio }\end{array}$ & $\begin{array}{l}\text { Labor } \\
\text { Ratio }\end{array}$ & $\begin{array}{l}\text { Effect of } \\
\text { Protection }\end{array}$ & $\begin{array}{l}\text { Hist. } \\
\text { Inj } . \\
\text { (F/DI/NDI) }\end{array}$ & $\begin{array}{l}\text { Proj. } \\
\text { Inj } \\
(F / D I / N D I)\end{array}$ \\
\hline $\begin{array}{l}\text { Struck by debris } \\
\text { or burnt while } \\
\text { operating miner }\end{array}$ & 1 & 1 & Medium & $1 / 2 / 1$ & $\begin{array}{l}\text { Less than } \\
1 / 2 / 1\end{array}$ \\
\hline $\begin{array}{l}\text { Burnt while doing } \\
\text { maintenance }\end{array}$ & 1.1 & 1 & Small & $1 / 1 / 0$ & $1 / 1 / 0$ \\
\hline $\begin{array}{l}\text { Struck by debris } \\
\text { or burnt while } \\
\text { operating roof } \\
\text { bolters }\end{array}$ & 2.5 & 1 & Medium & $1 / 1 / 1$ & $\begin{array}{l}\text { Less than } \\
3 / 3 / 3\end{array}$ \\
\hline
\end{tabular}

stoppings, clearing debris off tracks, etc. The single entry design and shotcrete liner employed by the tunnel borer reduce the need for these tasks con-. siderably. However, the beam and flexicore installation tasks are important contributors to hand-tool injuries because of the large workforce involved. Any tools (such as grappling hooks, slings, etc.) used in handling materials 
Table 5-9. Initial Injury Projection for Electrical Hazards

\begin{tabular}{|c|c|c|c|c|c|}
\hline Hazard/Activity & $\begin{array}{l}\text { Task } \\
\text { Time } \\
\text { Ratio }\end{array}$ & $\begin{array}{l}\text { Labor } \\
\text { Ratio }\end{array}$ & $\begin{array}{l}\text { Effect of } \\
\text { Protection }\end{array}$ & $\begin{array}{l}\text { Hist. } \\
\text { Inj. } \\
\text { (F/DI/NDI) }\end{array}$ & $\begin{array}{l}\text { Proj. } \\
\text { Inj } \\
\text { (F/DI/NDI) }\end{array}$ \\
\hline $\begin{array}{l}\text { Workers contact } \\
\text { energized con- } \\
\text { ductor while per- } \\
\text { forming maintenance }\end{array}$ & 1.1 & 1 & N/A & $2 / 67 / 25$ & $2 / 74 / 28$ \\
\hline $\begin{array}{l}\text { Workers contact } \\
\text { frayed cable while } \\
\text { doing cleanup }\end{array}$ & $3.4^{\circ}$ & 1 & Small & $0 / 2 / 0$ & $0 / 7 / 0$ \\
\hline $\begin{array}{l}\text { Workers contact } \\
\text { frayed cable while } \\
\text { cable reeling }\end{array}$ & 0 & 0 & N/A & $1 / 10 / 4$ & $0 / 0 / 0$ \\
\hline $\begin{array}{l}\text { Workers are tramming } \\
\text { or moving equipment } \\
\text { and contact energized } \\
\text { cable }\end{array}$ & 0.8 & 1 & Medium & $1 / 10 / 4$ & $\begin{array}{l}\text { Less than } \\
1 / 8 / 3\end{array}$ \\
\hline
\end{tabular}

would also tend to be used more in the beam, track, pipe, and flexicore installation activities. Consequently, an increase in exposure was projected for this hazard as well.

9. Initial Injury Projection for Pressure Release Hazards

Injuries caused by pressure release hazards are the last group of projections for the cunnel borer systeun. Table 5-12 indicates that the. majority of pressure release injuries occur during machine operation and maintenance. The projection shows an increase in maintenance-related injuries due to the greater exposure time, and no change in injuries associated with the operation of pneumatic equipment.

The last stage of the analysis involves a review of the initial injury projections by a group of safety experts. The results of this review are given in the next section.

\section{INJURY ADJUSTMENT BY THE GROUP OF EXPERTS}

The examination of the initial injury projections by a group of experts is designed to quantify the assigned ratings for protective measures, and to compensate for simplifying assumptions made in the analysis. For example, the analysis does not consider the possibility of hazards interacting with each other, and assumes that design changes which offer complete protection will 
Table 5-10. Initial Injury Projection for Slip and Fall hazards

\begin{tabular}{|c|c|c|c|c|c|}
\hline Hazard/Activity & $\begin{array}{l}\text { Task } \\
\text { Time } \\
\text { Ratio }\end{array}$ & $\begin{array}{l}\text { Labor } \\
\text { Ratio }\end{array}$ & $\begin{array}{l}\text { Effect of } \\
\text { Protection }\end{array}$ & $\begin{array}{l}\text { Hist. } \\
\text { Inj. } \\
\text { (F/DI/NDI) }\end{array}$ & $\begin{array}{c}\text { Proj. } \\
\text { Inj } . \\
(F / D I / N D I)\end{array}$ \\
\hline $\begin{array}{l}\text { Slip and fall off } \\
\text { machinery while } \\
\text { doing maintenance }\end{array}$ & 1.2 & 1 & Small & $0 / 60 / 20$ & $0 / 72 / 24$ \\
\hline $\begin{array}{l}\text { Slip and fall doing } \\
\text { cleanup }\end{array}$ & 4 & 1 & Small & $0 / 30 / 8$ & $0 / 120 / 32$ \\
\hline $\begin{array}{l}\text { Slip and fall while } \\
\text { handling awkward } \\
\text { materials }\end{array}$ & 2 & 2.6 & Small & $0 / 116 / 22$ & $0 / 603 / 114$ \\
\hline $\begin{array}{l}\text { Slip and fall off } \\
\text { rail cars, rerailing } \\
\text { cars, or coupling } \\
\text { cars }\end{array}$ & 1 & 1 & N/A & $0 / 118 / 49$ & $0 / 118 / 49$ \\
\hline $\begin{array}{l}\text { Slip and fall while } \\
\text { supervising or } \\
\text { escaping a hazard }\end{array}$ & 1 & 1 & N/A & $0 / 278 / 89$ & $0 / 278 / 89$ \\
\hline
\end{tabular}

mitigate all hazards. In some cases, these assumptions may not be well founded. It is for this reason that a group of experts with substantial experience in equipment design and safety are used to review the initial projections.

Four experts were chosen from the Bureau of Mines, Spokane, Washington; the Mine Safety and Health Administration (MSHA), Denver, Colorado; and the United Mine Workers (UMW), Washington, D.C. $(15,16,17)$. The Bureau of Mines expert was the Technical Project Manager for Tunneling Research at the time the tunnel borer research was initiated. The two experts from MSHA were selected from the Ground Support Division, and the Industrial Safety and Electrical Division. The UMW representative was selected from the office of Safety. All of the above participants had considerable underground mining experience.

The experts were familiarized with the safety issues involved in this assessment by the use of a briefing which covered the following topics:

(1) Graphic displays of the tunnel borer system.

(2) Complete descriptions of system components and operation for both the borer and continuous miner. 
Table 5-11. Initial Injury Projection for Hand-tool Hazards

\begin{tabular}{llllll}
\hline & $\begin{array}{l}\text { Task } \\
\text { Time } \\
\text { Ratio }\end{array}$ & $\begin{array}{l}\text { Labor } \\
\text { Ratio }\end{array}$ & $\begin{array}{l}\text { Effect of } \\
\text { Protection }\end{array}$ & $\begin{array}{c}\text { Hist. } \\
\text { Inj. } \\
\text { (F/DI/NDI) }\end{array}$ & $\begin{array}{c}\text { Proj. } \\
\text { Inj. } \\
\text { (F/DI/NDI) }\end{array}$ \\
\hline Hazard/Activity & 1.2 & 1 & N/A & $0 / 55 / 50$ & $0 / 66 / 60$ \\
$\begin{array}{l}\text { Tool slips or breaks } \\
\text { during maintenance }\end{array}$ & 2.3 & 3 & N/A & $0 / 277 / 331$ & $0 / 1911 / 2284$ \\
$\begin{array}{l}\text { Handtools slip or } \\
\text { break while being } \\
\text { used (not for maint- } \\
\text { enance, track re- } \\
\text { pair, cleanup, or } \\
\text { temporary support) }\end{array}$ & & & & & \\
$\begin{array}{l}\text { Tool slips while } \\
\text { handing supplies }\end{array}$ & 2 & 2.6 & N/A & $0 / 13 / 8$ & $0 / 68 / 42$ \\
\hline
\end{tabular}

(3) An examination of the major system failures and hazards for both the borer and continuous miner.

(4) An overview of the tunnel borer advantages and disadvantages, compared with the continuous miner.

(5) A summary, by accident class and hazard, of both the historical and projected injuries, showing the reasons for the projection as a function of exposure time, personnel changes, and protective measures.

The experts were provided hoth the historical and projected injury levels so as to have a baseline from which they could make their own projections. In the case of protective measures, they were asked to assign numerical values to the projected effect of the protective device on reducing injuries (e.g., a "much less than" rating could equate to a 90 to $100 \%$ reduction in injuries, and a "less than" rating could equate to a 50 to $70 \%$ reduction). The review process commenced with simply asking each expert whether he believed the actual injury level would be closer to the historical or projected level based on his experience and the indicated change in exposure time, workforce and protection. The range between the two injury levels was then cut in half and the experts were then asked to make another refinement of their estimate. This process continued until each expert reached a point where he could not refine his answer further. In most cases the final answer was provided as a range. Additionally, the reasons for each answer were also recorded. As a rule, though the experts varied in their perceptions of the injury magnitudes, the direction of the responses (i.e., either up or down) and the reasons given were consistent among the group. The final injury projection for each hazard was displayed as a range, encompassing 
Table 5-12. Initial Injury Projection for Pressure Release Hazards

\begin{tabular}{llllll}
\hline \multicolumn{1}{c}{} & $\begin{array}{l}\text { Task } \\
\text { Time } \\
\text { Ratio }\end{array}$ & $\begin{array}{l}\text { Labor } \\
\text { Ratio }\end{array}$ & $\begin{array}{l}\text { Effect of } \\
\text { Protection }\end{array}$ & $\begin{array}{c}\text { Hist. } \\
\text { Inj. } \\
\text { (F/DI/NDI) }\end{array}$ & $\begin{array}{c}\text { Proj. } \\
\text { Inj. } \\
\text { (F/DI/NDI) }\end{array}$ \\
\hline $\begin{array}{l}\text { Struck by whipping } \\
\text { hydraulic line } \\
\text { during maintenance. }\end{array}$ & 1.3 & 1 & N/A & $0 / 2 / 1$ & $0 / 3 / 1$ \\
$\begin{array}{l}\text { Struck by pneumatic } \\
\text { lines or fittings } \\
\text { while operating } \\
\text { equipment. } \\
\text { (Tunneling experience) }\end{array}$ & 1 & 1 & N/A & $0 / 6 / 0^{a}$ & $0 / 6 / 0$ \\
\hline
\end{tabular}

${ }^{a}$ Injuries per million manhours.

all of the experts answers. Each participant was interviewed separately and not apprised of the results of the other interviews. This approach insured that each participant was not biased by the other expert's responses. The following tables summarize the results of the interviews in the nine major hazard areas. Detailed results are given in Appendix B. The tunnel borer was compared against contemporary mining systems using the continuous miner as the baseline. The approximate yearly manhours worked by the continuous miner system are 200 million (18). Since the projected yearly injuries have already factored in adjustments for manhour increases and differences in manning levels via the analytical technique and inputs from the experts, both the historical and projected injury levels can be divided by the baseline manhours to establish comparable injury rates. This provides the injury rates in "injuries per million manhours", and allows a comparison of the tunnel borer safety performance with existing continuous miner injury rates and with the safety requirement. Since injury frequency correlates more strongly with exposure time than productivity, no attempt was made to balance differences in coal production to establish the comparative social cost of the tunnel borer as measured in injuries per ton.

1. Roof; Face, and Rib Fall Injuries

Table 5-13 shows that the experts generally agreed with the projections for injuries due to rock falls, with the exception of the maintenance hazard. In the case of maintenance at the face, the experts indicated that the exposure would be actually greater than initially anticipated because: (1) under bad roof conditions the support jacks could sustain more damage and thus increase maintenance time at the face, (2) workers are still in the face area long enough for stress buildup in the strata to cause falls, and (3) although the overall maintenance on continuous miner equipment at the face is greater than the tunnel borer, these components 
Table 5-13. Final Projections for Roof, Face, and Rib Fall Injuries

Hazard/Activity

Initial Injury Projection ( $F / D I / N D I)$
Adjustment by Experts (F/DI/NDI)
Struck while operating miner

Struck while performing maintenance

Struck while performing cleanup

Struck while testing or barring down roof, and roof bolting

Struck while operating haulage in the face area
Much less than

$3 / 42 / 14$

$0 / 13 / 4$

Less than

$1 / 42 / 8$

Less than

$8 / 185 / 77$

Much less than

$1 / 28 / 9$
$0 / 0-4 / 0-1$

$0-1 / 13-36 / 4-8$

$0 / 10-20 / 3-5$

0/46-93/19-39

$0 / 3-6 / 1-2$

are not always repaired in the face area thus reducing actual exposure closer to that of the tunnel borer. The net result of these comments was an adjustment of the projection upward toward of the historical level. The experts felt that protection provided by the circular entry design, permanent protection closer to the face, and the protection of the tunneling machine itself provided a substantial reduction in the fall hazard associated with cleanup. The fall hazard related to the conventional roof testing, temporary support, and bolting task also received a large downward adjustment. The reasons for this are twofold. First, the experience of the experts indicated that the greatest portion of serious injuries occur while testing, barring down roof, and placing temporary support. Historical injury data confirmed this observation (19). Second, the protection offered by the circular entry design, placement of permanent support closer to the face, and the roof bolter canopy greatly reduces exposure. The largest factor given for mitigating injuries caused by rock falls while operating haulage was the elimination of shuttle cars from the system. The total yearly projected injuries for all hazards in this accident class came to 0 to 4 fatalities, 119 to 208 disabling injuries, and 39 to 69 nondisabling injuries. The injuries per million manhours then became respectively 0 to 0.02 fatalities, 0.6 to 1 disabling injuries, and 0.8 to 1.2 overall injuries.

\section{Haulage Injuries}

Major hazard reductions associated with removing the loader and shuttle cars from the system were confirmed by the experts. Tahle 5-14 also shows that the experts agree that exposure to derailments, and being caught or pinched while riding or getting on and off equipment would remain basically 
Table 5-14. Final Projections for Haulage Injuries.

\begin{tabular}{|c|c|c|}
\hline Hazard/Activity & $\begin{array}{l}\text { Injury Projection } \\
(\mathrm{F} / \mathrm{DI} / \mathrm{NDI})\end{array}$ & $\begin{array}{c}\text { Adjustment by Experts } \\
(\mathrm{F} / \mathrm{DI} / \mathrm{NDI})\end{array}$ \\
\hline $\begin{array}{l}\text { Operator or helper caught } \\
\text { or struck by loader }\end{array}$ & $0 / 0 / 0$ & $0 / 0 / 0$ \\
\hline $\begin{array}{l}\text { Operator or workers pinched } \\
\text { or struck by shuttle car }\end{array}$ & $0 / 0 / 0$ & $0 / 0 / 0$ \\
\hline $\begin{array}{l}\text { Pinched while rerailing cars, } \\
\text { or during derailment }\end{array}$ & $1 / 108 / 42$ & $1 / 86-108 / 33-42$ \\
\hline $\begin{array}{l}\text { Pinched or struck getting } \\
\text { on or off equipment, or } \\
\text { riding equipment }\end{array}$ & $2 / 222 / 66$ & $2 / 222 / 66$ \\
\hline $\begin{array}{l}\text { Workers struck while } \\
\text { spotting or coupling cars, } \\
\text { and laying or repairing track }\end{array}$ & $0 / 101 / 24$ & $0 / 101 / 24$ \\
\hline $\begin{array}{l}\text { Struck while handing mater- } \\
\text { ials and working with } \\
\text { handtools in area of moving } \\
\text { haulage }\end{array}$ & $0 / 179 / 31$ & $0 / 125-179 / 22-31$ \\
\hline
\end{tabular}

unchanged. Expert comments on these hazards pointed out that: (1) bumps in the track due to floor heave, and the ramp at the California switch, provide causes for derailments on about the same scale as any other rail haulage system; (2) workers can still operate the rail cars faster than they should, resulting in derailments; and (3) workers often do not wait for equipment to stop before getting on or off. The last two above sources of injuries are human errors which appear to be inherent in any rail system.

Two other hazards, which historically have not resulted in as many injuries as the above hazards, received considerable attention from the experts. These sources of injuries were: (1) workers being struck or pinched while coupling cars, and (2) workers being struck while handling materials in the area of moving haulage. The projected increase in injuries for these hazards stemed from a large number of workers being involved in the flexicore installation activity, increased rail car activity, and cleanup around the loading hopper. Though the experts basically agreed with the projections, they felt that improved visibility of operations due to the equipment layout slightly mitigated the handling material hazard. Injury projections for these additional hazards are also displayed in Table 5-14. The total yearly projected injuries for this accident class was 5 fatalities, 625 to 745 disabling injuries, and 163 to 192 nondisabling injuries. This resulted respectively in 0.03 fatalities per million manhours, 3.1 to 3.7 disabling injuries per million manhours, and 3.9 to 4.7 overall injuries per million manhours. 
Table 5-15 indicates that the experts generally concurred with the initial projections. All the experts agreed that remote operation would reduce exposure to being struck while operating the miner. It is interesting to note that although the experts felt the increased cleanup time around machinery increased the chance of injury, the equipment layout was considered an important factor in helping to mitigate this hazard. The most important adjustment made to machinery hazards resulted in a reduced injury projection for the roof bolter. The reasons for this downward adjustment centered around: (1) the reduced size and mass of the bolters, (2) the constrained movement of the bolters, and (3) the simpler bolting procedure (i.e., less moving and positioning). However, the experts observed no.design improvements to offset the hazards associated with the standard tunneling machinery.

The total projected injuries per million manhours for the machinery accident class are 0.01 fatalities, 22 to 23 disabling injuries, and 24 to 27 overall injuries per million manhours.

\section{Handling Material Injuries}

The impact of the key handling material hazards remained basically unchanged after review by the experts. Table 5-16 shows that the experts did not feel any adjustment was necessary for the hazards of dropping machine components and dropping material while doing cleanup. Their joint experience suggested that more time spent handling materials increases the chance of being struck or pinched by materials. This same reasoning applied to the projected increase in injuries resulting from handling supplies. The experts felt that although the hoists would help mitigate this hazard somewhat by not requiring workers to carry supplies, substantial handling would still be required while attaching components to the hoists and positioning them. Consequently, the adjusted injuries were slightly lower than the original projection, but considerably higher than the historical level. The original projection for the cable handling hazard indicated total elimination of injuries because the effort was reduced to a minimal hanging cable task. The experts notcd that pinch points still exist when attaching the cable to the rib. Thus, injuries to the hands or arms would still be possible. The total projected handling material injuries are 0 fatalities, 4086 to 7427 disabling, and 1344 to 2355 nondisabling. This equates to injury rates of 0 fatalities, 20 to 37 disabling injuries per million manhours, and 27 to 49 overall injuries per million manhours.

\section{Explosion and Fire Injuries}

The chief explosion and fire hazards are caused by sparks generated by the cutters, bolters, or tools and electrical components which in turn ignite gas or cause a fire. Table 5-17 indicates that the experts generally felt the ventilation, shotcrete lining and degasification would be adequate to offset the hazard of machinery igniting gas. However, it was noted that the gas monitor, being located twelve feet. from the face, could allow enough gas to build up to cause minor ignitions and slightly aggravate the explosion hazard. The experts felt that the poor location of the gas 
Table 5-15. Final Projections for Machinery Injuries

\begin{tabular}{|c|c|c|}
\hline Hazard/Activity & $\begin{array}{l}\text { Injury Projection } \\
(\mathrm{F} / \mathrm{DI} / \mathrm{NDI})\end{array}$ & $\begin{array}{l}\text { Adjustment by Experts } \\
\text { (F/DI/NDI })\end{array}$ \\
\hline $\begin{array}{l}\text { Operator or helper } \\
\text { struck while operating } \\
\text { miner }\end{array}$ & $\begin{array}{l}\text { Much less than } \\
0 / 94 / 34\end{array}$ & $0 / 0-9 / 0-3$ \\
\hline $\begin{array}{l}\text { Struck while doing } \\
\text { cleanup and using hand tools }\end{array}$ & $\begin{array}{l}\text { Less than } \\
0 / 152 / 80\end{array}$ & $0 / 76-152 / 40-80$ \\
\hline $\begin{array}{l}\text { Struck while moving or } \\
\text { operating roof bolters }\end{array}$ & $\begin{array}{l}\text { Less than } \\
3 / 1290 / 438\end{array}$ & $0 / 516-645 / 219-438$ \\
\hline $\begin{array}{l}\text { Struck or caught while } \\
\text { operating large drills, } \\
\text { shotcrete machinery, or hoists } \\
\text { (Tunneling industry data) }\end{array}$ & $0 / 18 / 19^{a}$ & $0 / 18 / 19^{a}$ \\
\hline
\end{tabular}

${ }^{2}$ Injuries per million manhours

Table 5-16. Final Projections for Handling Material Injuries

\begin{tabular}{llc} 
Hazard/Activity & Initial $\begin{array}{l}\text { Injury Projection } \\
(\mathrm{F} / \mathrm{DI} / \mathrm{NDI})\end{array}$ & $\begin{array}{c}\text { Adjustment by Experts } \\
\text { (F/DI/NDI) }\end{array}$ \\
\hline $\begin{array}{l}\text { Worker drops component } \\
\text { while doing maintenance }\end{array}$ & $0 / 307 / 169$ & $0 / 307 / 169$ \\
$\begin{array}{l}\text { Struck while handling } \\
\text { material during cleanup }\end{array}$ & $0 / 444 / 168$ & $0 / 444 / 168$ \\
$\begin{array}{l}\text { Pinched or struck while } \\
\text { handling supplies }\end{array}$ & $0 / 6469 / 1898$ & $0 / 3235-6469 / 949-1898$ \\
$\begin{array}{l}\text { Injured handling power cables } \\
\text { n }\end{array}$ & $0 / 0 / 0$ & $0 / 0-34 / 0-10$
\end{tabular}

monitor, coupled with use of flamable hydraulic fluid, also increased exposure to fires during maintenance. The total injuries for all hazards in the explosion and fire accident class are 3 to 5 fatalities, 3 to 6 disabling injuries, and 3 to 5 nondisabling injuries. This results respectively in 0.02 to 0.03 . fatalities per million manhours, 0.02 to 0.03 disabling injuries per million manhours, and 0.05 to 0.08 overall injuries per million manhours. 
Table 5-17. Final Projections for Explosion and Fire Injuries

Hazard/Activity

Initial Injury Projection (F/DI/NDI)

Adjustment by Experts (F/DI/NDI)

Struck by debris or burnt

Less than

while operating miner and

$4 / 5 / 4$

$0-2 / 0-3 / 0-2$

roof bolters

Burnt while doing maintenance

$1 / 1 / 0$

$2 / 2 / 1$

\section{Electrical Injuries}

Table 5-18 shows a modest downward adjustment of the maintenance injury projection. Although the experts basically agreed that the slight increase in electrical maintenance would increase exposure, it was felt that the amount of cable maintenance and outby electrical maintenance (i.e., switch boxes, etc.) for the continuous miner was somewhat underestimated. This would tend to make the overall exposure between the two systems approximately equal. Therefore, it was felt that the actual injury level would be within the range of both the historical and projected levels. The experts adjusted the cleanup related injuries back down to the historical level because it was felt that the relative permanency of the cable locations would allow workers to always know where the cables are located. Since the tunnel borer cable handling activity is greatly reduced due to the equipment layout and removal of the main power cable from the work areas, the experts concurred with the original projection. Injuries related to moving and tramming equipment were also adjusted downward for the equipment layout and cable removal reasons. The total yearly injuries for all electrical hazards results in 4 fatalities, 116 to 128 disabling injuries, and 59 to 64 nondisabling injuries. This equates to 0.02 fatalities per million manhours, 0.6 disabling injuries per million manhours, and 1 overall injury per million manhours.

\section{Slip and Fall Injuries}

The adjustments shown in Table 5-19 generally reflect the experts' assessment of the advantages of improved lighting, the reduction of obstacles such as rib slough, and the reduction in equipment conjestion because of the straight line layout. One hazard which historically has not contributed many injuries is workers "slipping or falling while operating machinery other than the mining machine or haulage". This received considerable attention from the experts because of the high labor intensiveness of the shotcrete and hoist activities. The experts felt that workers had a greater chance of falling during the hoist activities due to the congestion (i.e., workers could slip and knock others off balance). In addition, it was felt that workers could slip and fall during the shotcrete task as a result of standing-water on the floor. The improved lighting was believed to reduce these hazards only marginally. 
Table 5-18. Final Projections for Electrical Injuries

Hazard/Activity
Initial Injury Projection (F/DI/NDI)
Adjustment by Experts

(F/DI/NDI)

Workers contact energized conductor while performing

$2 / 74 / 28$

$2 / 67-74 / 25-28$

maintenance

Workers contact frayed cable

$0 / 7 / 0$

$0 / 2 / 0$

while doing cleanup

Workers contact frayed cable

$0 / 0 / 0$

$0 / 0 / 0$

while cable reeling

Workers are tramming or

moving equipment and contact

energized cable

Less than

$1 / 8 / 3$

$0 / 0-3 / 0-1$

Hazard/Activity

Initial Injury Projection

( $F / D I / N D I)$
Adjustment by Experts

(F/DI/NDI)

slip and fall off machinery

$0 / 72 / 24$

$0 / 61-72 / 20-24$

while doing maintenance

Slip and fall doing cleanup

$0 / 120 / 32$

$0 / 60-120 / 16-32$

Slip and fall while handing awkward materials and handtools

$0 / 679 / 144$

$0 / 679 / 144$

to install components

Slip and fall off rail cärs, rerailing cars, or coupling cars

Slip and fall while supervising or escaping a hazard

Slip and fall while moving or operating other machinery

$0 / 118 / 49$

$0 / 94-118 / 39-49$

$0 / 278 / 89$

0/209-278/67-89

$0 / 334 / 121$

$0 / 284-334 / 103-121$ 
The total yearly projected slip and fall injuries are 0 fatalities, 1413 to 1631 disabling injuries, and 398 to 469 nondisabling injuries. This results in 0 fatalities per million manhours, 7 to 8 disabling injuries per million manhours, and 9 to 11 overall injuries per million manhours.

\section{Hand-tool Injuries}

As shown in Table 5-20, the experts agreed on two of the three major hazard projections for hand-tool injuries. The only deviation from the initial projections concerned the general use of tools for activities similar to outby support (i.e., rebuilding stoppings, moving and storing supplies, installing cribbing, etc.). Although two of the experts agreed with the projected increase because of the labor intensiveness of the beam, track, and flexicore installation activities, the third expert adjusted the projection slightly downwards. The continuous miner system typically employs several outby support crews working in the crosscuts. This would tend to bring the comparative workforce and manhour ratios closer together. At the same time is was agreed that the beam and flexicore tasks were performed on a more continuous basis than normal continuous miner outby support activities. Overall, these factors tended to place the actual injury level somewhere between the historical experience and the initial projection.

The total yearly injuries for all hand-tool hazards are 0 fatalities, 825 to 2136 disabling injuries, and 2470 nondisabling injuries. This equates to 0 fatalities per million manhours, 4 to 11 disabling injuries per million manhours, and 16 to 23 overall injuries per million manhours.

\section{Pressure Release Injuries}

Table 5-21 shows that even with an initially projected increase in exposure time, and resultant rise in maintenance related injuries, the experts adjusted the projection upwards. This was because it was felt that the size and complexity of the tunnel borer system provided more opportunities for hydraulic and pneumatic failures. The experts agreed that pneumatic-related injuries would be elose to hiotorical experience in tunneling operations. The total yearly injury rates for all pressure release hazards are 0 fatalities per million manhours, 6 disabling injuries.per million manhours, and 6 overall injuries per million manhours.

The preceding tables, showing the final injury projections for the major hazards, clearly indicate that the major weaknesses in the tunnel borer system stem from the extra tunneling machinery used and from the installation of the tunnel divider. Section VI provides a detailed comparison of the injury rates of the tunnel borer and continuous miner system, revealing the strengths and weaknesses of the tunnel borer system as presently designed. 
Table 5-20. Final Projections for Hand-tool Injuries

Hazard/Activity

Initial Injury Projection (F/DI/NDI)

$0 / 66 / 60$

$0 / 1911 / 2284$

$0 / 600-1911 / 2284$

Handtools slip or break while being used, mostly outby support

Tool slips while handling supplies

$0 / 68 / 42$
Adjustment by Experts $(\mathrm{F} / \mathrm{DI} / \mathrm{NDI})$
Tool slips or breaks during maintenance

$0 / 66 / 60$
$0 / 68 / 42$

.

Table 5-21. Final Projections for Pressure Release. Injuries

Hazard/Activity

Initial Injury Projection ( $F / D I / N D I)$
Adjustment by Experts

( F/DI/NDI)

Struck by whipping hydraulic

$0 / 3 / 1$

$0 / 3-6 / 1-2$

line during maintenance

Struck by pneumatic lines or fittings while operating

$0 / 6 / 0^{a}$

$0 / 6 / 0^{a}$ equipment (Tunneling experience)

${ }^{a}$ Injuries per million manhours 


\section{SECTION VI}

\section{CONCLUSIONS}

\section{A. OVERVIEW}

This section assembles all of the injury projections given in Section $v$ and provides a comparison of the tunnel borer safety performance against both the continuous miner injury levels, and the safety requirement previously developed for advanced mining systems (2). Strengths and weaknesses of the tunnel borer system are analyzed in light of the preceding safety analysis, and design changes are suggested for the hazard areas which present serious safety problems.

\section{B. COMPARISON OF INJURY RATES}

\section{Continuous Miner Injury Rate Comparison}

The results of the quantitative evaluation suggest that the tunnel borer system offers both advantages and disadvantages when compared with the continuous miner system. The major differences between the two systems are highlighted in Table 6-1, which compares continuous miner historical injuries to the final projections for the tunnel borer, by major accident class.

The use of a circular entry, shotcrete, roof bolts, tunnel divider, and remote operation were deciding factors in substantially mitigating roof fall hazards. Table 6-1 indicates a reduction in fatalities by a factor of ten, and disabling injuries by a factor of three in this area. The key elements which contributed to a reduction in serious haulage injuries (a $50 \%$ reduction in fatalities, and roughly a 15 to $20 \%$ reduction in disabling injuries), were the elimination of shuttle cars and the placement of the conveyor away from the working areas. The machinery injury rates shown in Table 6-1 are broken down into injuries related to coal mining components and injuries related to tunneling components. This was done to demonstrate the strong and weak points of the tunnel borer. The prereding analysis indicates that serious injuries could be decreased by: (1) reducing the unpredictability of machinery movement and position, (2) reducing the mobility of machinery, and ( 3 ) integrating machine functions to reduce place changing. These elements were incorporated in the tunnel borer design through the layout of equipment, constraining both the miner and roof bolters to only move in one direction, and by integrating the roof bolters with the miner. Consequently, the serious injury projection for the basic components of mining machine and bolters was lower than the historical rates experienced by the continuous miner. However, Table 6-1 also shows that this improvement was offset by the use of other pieces of tunneling machinery. The disabling injury rate for machine hazards was further aggravated by the large workforce employed for the shotcrete and tunnel divider activities. This tended to expose more workers for a longer period of time to hazards such as being struck while handling supplies, or being struck by other moving machinery while doing cleanup and working with hand tools. The factor which effected handling material. injuries the most was the beam and flexicore installation activities. The increased exposure of workers to hazards related to installing the tunnel divider accounted for roughly $80 \%$ of the total disabling injury projection. The experts agreed that even with the hoists, 
Table 6-1. Detailed Injury Rate Comparison for the Continuous Miner (CM) and Tunnel Borer (TB) Systems, by Accident Class (yearly injuries per million manhours)

\begin{tabular}{|c|c|c|c|c|}
\hline \multirow[b]{2}{*}{ Accident Class } & \multicolumn{2}{|c|}{ Fatalities } & \multirow{2}{*}{$\begin{array}{c}\text { Disabling } \\
\text { CM }\end{array}$} & \multirow{2}{*}{$\underset{T B}{\text { Injuries }}$} \\
\hline & CM & $\mathrm{TB}$ & & \\
\hline $\begin{array}{l}\text { Roof, face, rib falls } \\
\text { Haulage }\end{array}$ & $\begin{array}{l}0.14 \\
0.06\end{array}$ & $\begin{array}{l}0-0.02 \\
0.03\end{array}$ & $\begin{array}{l}3 \\
4\end{array}$ & $\begin{array}{l}0.6-1 \\
3.1-3.7\end{array}$ \\
\hline Miner and roof bolter & 0.03 & 0.01 & 5 & $4-5$ \\
\hline $\begin{array}{l}\text { Hoists, degas drill, } \\
\text { and shotcrete }\end{array}$ & 0 & 0 & 0 & 18 \\
\hline Handling material & 0 & 0 & 11 & $20-37$ \\
\hline Explosion/fire & 0.03 & $0.02-0.03$ & 0.03 & $0.02-0.03$ \\
\hline Electrical & 0.02 & 0.02 & 1 & 0.6 \\
\hline Slip/fall & 0 & 0 & 4 & $7-8$ \\
\hline Handtools & 0 & 0 & 2 & $4-11$ \\
\hline Pressure bursts & 0 & 0 & 0 & 6 \\
\hline Total & .3 & $0.08-0.1$ & 30 & $63-90$. \\
\hline
\end{tabular}

workers still had considerable opportunities to be injured. In conjunction with increased handling material injuries, the handtool projection envisions a two to five fold increase in serious injuries as a result of the work required to install the tunnel divider.

As shown previously, the explosion hazard was mitigated by the degasification feature. However a projected increase in exposure to fire during maintenance offset the reduced explosion potential, resulting in injury rates similar to existing experience in continuous mining sections. The potential for injury from electrical shock was somewhat mitigated by the removal of the main power cable from the work areas, and the improved equipment layout which essentially eliminated the cable handiing task. The equipment layout also reduced the chance of cable damage due to equipment impact. This resulted in almost a 50\% reduction in disabling injuries. The last major accident class affected, pressure release, experienced a substantial increase in injuries because of the greater use of high pressure hydraulics and pneumatics on the tunnel borer equipment. The hoists and shotcrete machinery were the major sources for this projected increase.

In total, the tunnel borer demonstrates a marked improvement over the continuous miner in fatalities for the nine dominant accident classes shown in Table 6-1. However, the tunnel borer is roughly a factor of two to three higher in disabling injuries. Furthermore, the serious weaknesses of the tunnel borer revolve around the increased machinery used and the extensive material handling associated with the tunnel divider construction. It is also interesting to note that the first eight accident classes shown in Table 6-1 compose the bulk of the total injuries (in excess of $76 \%$ ) experienced in underground mining. There are thirteen remaining accident classes which, when 
considering their injury rates, result in total yearly injury rates for continuous mining of approximately 0.33 fatalities per million manhours, 40 disabling injuries per million manhours, and 55 overall injuries per million manhours. In comparison, the tunnel borer system is still roughly two times higher in both disabling and overall injury rates.

\section{Safety Requirement Injury Rate Comparison}

Comparison of the tunnel borer injury rate projections with the safety requirement given in Table 6-2 shows that the tunnel borer system meets the fatality rate, but far exceeds the disabling and overall injury rates.

Table 6-2. Comparison of Injury Rates for the Tunnel Borer System with the Safety, Requirements (yearly injuries per million manhours)

In jury Categories

Projected Tunnel

Borer Injuries

Safety Requirement

Fatalities

$0.08-0.1$

0.2

Disabling Injuries

$63-90$

30

Overall Injuries

100

40-45

Thus the data indicate that the tunnel borer system, as presently designed, would not be considered an advanced system. An additional criterion to be met by an advanced system is a demonstration of improved safety in the four accident classes which historically contribute the bulk fatalities and disabling injuries. These classes are, in order of severity, rock falls, haulage, machinery, and handling materials. Table 6-1 clearly shows that the tunnel borer system affects a reduction in only the first two classes.

\section{SUGGESTED AREAS FOR DESIGN IMPROVEMENT}

It appears that some obvious design changes can be made by analyzing the major safety problems associated with the tunnel borer. As shown in the previous section, the integration of the excavator and roof bolter has a favorable safety impact. However, the additional use of tunneling equipment aggravated the hazards. The requirement to install the tunnel divider originated from the MSHA ventilation regulation, which requires that both intake and exhaust airways be provided. This would also provide two means of escape for workers in the event of explosion or fire. In the process of meeting this regulation, the tunnel borer system partially offset the explosion and fire hazards by a design redundancy which employed degasification, higher face ventilation, and flexicore installation. This design appeared sound but, in examining the relative contribution to reducing serious injuries, had relatively little impact on an already low injury rate. 
Furthermore, the flexicore installation resulted in a major increase in the machinery and handling material injuries. This is not meant to imply that emphasis should not be placed on the explosion hazard. What this finding does imply is that exact compliance with regulations, without analyzing the possible side effects, can result in hazards being shifted from one area to another. This finding further implies that the emphasis placed on using state-of-the-art system components should have been replaced with a total system analysis of new technology and methods for ventilation and gas control. The use of alternative gas bleeding, collecting, or monitoring systems could possibly be employed at the face in a redundant fashion so that the intent of the ventilation regulations could still be met, with the complete elimination of the tunnel divider activity. The next stage in the analysis would be to investigate alternative ways of managing the ventilation problems so as to not increase hazards in this area, and also investigate alternatives to the unwieldy tunneling equipment, such as the hoists, shotcrete machinery, and degasification drill. 


\section{REFERENCES}

1. Injury Experience in Coal Mining, Mining Safety and Health Administration, U.S. Department of Labor, 1976-1979.

2. Zimmerman, W. F., Safety Evaluation Methodology for Advanced Coal Extraction Systems, JPL Publication 81-54, Jet Propulsion Laboratory, Pasadena, California, July 15, 1981.

3. Cobb, J. A., et al., A Study of the Feasibility of Tunnel Boring Machines for Coal Mine Development, Cobb Engineering, 1973.

4. Voss, J., et al., Safety Assessment of the Tunnel Boring Machine, Battelle Pacific Northwest Laboratories, Richland, Washington, 1979.

5. Coal Employment and Injury National Summary by Month, 1976-1979, Report No. CM34lL2, Mining Safety and Health Administration, 1980 .

6. Demonstration of a Tunnel Boring Machine for Coal Mine Development, Contract No. SO-144075, U. S. Bureau of Mines, 1973.

7. Zimmerman, W. F., Health Requirements for Advanced Coal Extraction Systems, JPL Publication 80-72, Jet Propulsion Laboratory, Pasadena, California, September 15, 1980.

8. J. F. Shea Co., Pomona, California, Interview, April 23, 1981.

9. Guy F. Atkinson Co., San Francisco, California, Interview and site visit to the Gilroy Dam Project, Interview, May 5, 1981.

10. Jarva Co., The 1981 International Tunneling Conference, San Francisco, California, Interview, May 6-7, 1981.

11. Robbins Co., The 1981 International Tunneling Conference, San Francisco, California, Interview, May G-7, 1981.

12. Detailed Injury Tabulation for Tunneling Operations West of the Mississippi River, 1976-1979, Bureau of Reclamation, Denver, Colorado, 1981 .

13. Pfleider, E. P., and Krug, A. D., The Development of Health and Safety Indices for the Evaluation of Underground Coal Mining Systems, University of Minnesota, November 1973.

14. Industrial Engineering Study of Continuous Mining Systems, J. J. Davis Associates Inc., 1976.

15. Serbousek, M., Bureau of Mines, Spokane, Washington, Interview, August 17,1981 . 
16. Hollett, E., and Hutchinson, D., MSHA, Denver, Colorado, Intervirw, August 19, and September 24, 1981.

17. Davidson, D., UMW Headquarters, Washington, D.C.,. Interview, August 20, 1981 .

18. Tabular Report ABO-60LA, Mining Safety and Health Administration, 1979.

19. Tables for Falls of Roof, Face and Rib Fatalities in Underground Coal Mines for the Years 1972-1978, MSHA Health and Safety Analysis Center, Denver, Colorado, 1979 . 
APPENDIX A

DETAILED INJURY PROJECTIONS BY ACC IDENT CLASS AND HAZARD 


\section{THIS PAGE}

\section{WAS INTENTIONALLY \\ LEFT BLANK}

A-2 
Accident Class: Roof, face, rib falls

\begin{tabular}{|c|c|c|c|c|c|c|}
\hline Hazard/Activity & $\begin{array}{l}\text { Task } \\
\text { Time } \\
\text { Ratio }\end{array}$ & $\begin{array}{l}\text { Labor } \\
\text { Ratio }\end{array}$ & $\begin{array}{l}\text { Potential } \\
\text { Effect of } \\
\text { Protective } \\
\text { Measure }\end{array}$ & $\begin{array}{l}\text { Hist. } \\
\text { Inj . } \\
(\mathrm{F} / \mathrm{DI} / \mathrm{NDI})\end{array}$ & $\begin{array}{l}\text { Proj. } \\
\text { Inj } \\
(F / D I / N D I)\end{array}$ & \\
\hline $\begin{array}{l}\text { Operator, helper struck } \\
\text { while operating miner. }\end{array}$ & \multicolumn{2}{|c|}{$\begin{array}{l}\text { Protective } \\
\text { measure }\end{array}$} & Large & $3 / 42 / 14$ & $\begin{array}{l}\text { Much less } \\
3 / 42 / 14\end{array}$ & than \\
\hline $\begin{array}{l}\text { Struck while performing } \\
\text { maintenance in face area. }\end{array}$ & 0.35 & 1 . & Sma11 & $1 / 36 / 8$ & $0 / 13 / 4$ & \\
\hline $\begin{array}{l}\text { Struck while performing } \\
\text { cleanup in face area. }\end{array}$ & 0.6 & 1 & Medium & $2 / 70 / 13$ & $\begin{array}{l}\text { Less than } \\
1 / 42 / 8\end{array}$ & \\
\hline $\begin{array}{l}\text { Struck while testing } \\
\text { roof, barring down } \\
\text { rock and roof } \\
\text { bolting. }\end{array}$ & 0.6 & 1 & Medium & $14 / 309 / 129$ & $\begin{array}{l}\text { Less than } \\
8 / 185 / 77\end{array}$ & \\
\hline $\begin{array}{l}\text { Struck while performing } \\
\text { environmental checks in } \\
\text { between place changes. }\end{array}$ & \multicolumn{2}{|c|}{$\begin{array}{l}\text { Protective } \\
\text { measure }\end{array}$} & Large & $0 / 4 / 1$ & $\begin{array}{l}\text { Much less } \\
0 / 4 / 1\end{array}$ & than \\
\hline $\begin{array}{l}\text { Struck while operating } \\
\text { haulage in face area. }\end{array}$ & \multicolumn{2}{|c|}{$\begin{array}{l}\text { Protective } \\
\text { measure }\end{array}$} & Large & $1 / 28 / 9$ & $\begin{array}{l}\text { Much less } \\
1 / 28 / 9\end{array}$ & than \\
\hline $\begin{array}{l}\text { Struck while handling or } \\
\text { reeling cable. }\end{array}$ & 0 & 0 & N/A & $1 / 15 / 2$ & $0 / 0 / 0$ & \\
\hline $\begin{array}{l}\text { Struck while setting } \\
\text { brattice. }\end{array}$ & 0 & 0 & N/A & $1 / 18 / 3$ & $0 / 0 / 0$ & \\
\hline $\begin{array}{l}\text { Struck while operating } \\
\text { or rerailing rail cars, } \\
\text { or repairing track. }\end{array}$ & \multicolumn{2}{|c|}{$\begin{array}{l}\text { Protective } \\
\text { measure }\end{array}$} & Large & $0 / 4 / 4$ & $\begin{array}{l}\text { Much less } \\
0 / 4 / 4\end{array}$ & than \\
\hline $\begin{array}{l}\text { Struck while escaping } \\
\text { hazard or during accident } \\
\text { recovery. }\end{array}$ & \multicolumn{2}{|c|}{$\begin{array}{l}\text { Protective } \\
\text { measure }\end{array}$} & Medi um & $2 / 7 / 2$ & $\begin{array}{l}\text { Less than } \\
2 / 7 / 2\end{array}$ & \\
\hline $\begin{array}{l}\text { Struck while riding } \\
\text { equipment to working } \\
\text { area. }\end{array}$ & \multicolumn{2}{|c|}{$\begin{array}{l}\text { Protective } \\
\text { measure }\end{array}$} & Large & $0 / 5 / 3$ & $\begin{array}{l}\text { Much less } \\
0 / 5 / 3\end{array}$ & than \\
\hline Struck while supervising & 1 & 1 & N/A & $2 / 44 / 11$ & $2 / 44 / 11$ & \\
\hline
\end{tabular}


Accident Class: Haulage

\begin{tabular}{|c|c|c|c|c|c|}
\hline Hazard/Activity & $\begin{array}{l}\text { Task } \\
\text { Time } \\
\text { Ratio }\end{array}$ & $\begin{array}{l}\text { Labor } \\
\text { Ratio }\end{array}$ & $\begin{array}{l}\text { Potential } \\
\text { Effect of } \\
\text { Protective } \\
\text { Measure }\end{array}$ & $\begin{array}{l}\text { Hist. } \\
\text { Inj. } \\
(\mathrm{F} / \mathrm{DI} / \mathrm{NDI})\end{array}$ & $\begin{array}{l}\text { Proj. } \\
\text { Inj } \\
(F / D I / N D I)\end{array}$ \\
\hline $\begin{array}{l}\text { Miner operator or helper } \\
\text { caught or struck by } \\
\text { loader. }\end{array}$ & 0 & 0 & N/A & $3 / 94 / 26$ & $0 / 0 / 0$ \\
\hline $\begin{array}{l}\text { Workers struck while } \\
\text { operating or articulating } \\
\text { conveyor. }\end{array}$ & $\begin{array}{l}\text { Prot } \\
\text { meas }\end{array}$ & $\begin{array}{l}\text { ctive } \\
\text { re }\end{array}$ & Large & $0 / 14 / 2$ & $\begin{array}{l}\text { Much less than } \\
0 / 14 / 2\end{array}$ \\
\hline $\begin{array}{l}\text { Workers struck by loader } \\
\text { or conveyor during cleanup. }\end{array}$ & 0.5 & 1 & Sma11 & $1 / 8 / 2$ & $1 / 4 / 1$ \\
\hline $\begin{array}{l}\text { Workers struck by loader, } \\
\text { conveyor, or rail car } \\
\text { doing maintenance in area. }\end{array}$ & 0.8 & 1 & Sma11 & $1 / 32 / 6$ & $1 / 26 / 5$ \\
\hline $\begin{array}{l}\text { Workers pinched while } \\
\text { spotting or coupling. } \\
\text { rail cars. }\end{array}$ & 1.7 & 1 & N/A & $0 / 55 / 13$ & $0 / 94 / 22$ \\
\hline $\begin{array}{l}\text { Workers struck while } \\
\text { reeling or handling } \\
\text { cable. }\end{array}$ & 0 & 0 & N/A & $0 / 10 / 2$ & $0 / 0 / 0$ \\
\hline $\begin{array}{l}\text { Workers struck while } \\
\text { laying or repairing } \\
\text { track. }\end{array}$ & 1 & 1 & $\mathbf{N} / \mathbf{A}$ & $0 / 7 / 2$ & $0 / 7 / 2$ \\
\hline $\begin{array}{l}\text { Workers struck while } \\
\text { operating other equip- } \\
\text { ment in area of moving } \\
\text { haulage. }\end{array}$ & 1.6 & 2 & N/A & $0 / 23 / 6$ & $0 / 74 / 19$ \\
\hline $\begin{array}{l}\text { Workers pinched while } \\
\text { rerailing equipment, } \\
\text { or operator pinched in } \\
\text { derailment. }\end{array}$ & $\mathrm{i}$ & 1 & N/A & $1 / 108 / 42$ & $1 / 108 / 42$ \\
\hline $\begin{array}{l}\text { Struck while handling } \\
\text { materials and working } \\
\text { with handtools ( } i . e ., \\
\text { includes cleanup but } \\
\text { not maintenance). }\end{array}$ & 1.3 & 3 & N/A & $0 / 46 / 8$ & $0 / 179 / 31$ \\
\hline
\end{tabular}


Accident Class: Haulage (Cont'd)

\begin{tabular}{|c|c|c|c|c|c|}
\hline Hazard/Activity & $\begin{array}{l}\text { Task } \\
\text { Time } \\
\text { Ratio }\end{array}$ & $\begin{array}{l}\text { Labor } \\
\text { Ratio }\end{array}$ & $\begin{array}{l}\text { Potential } \\
\text { Effect of } \\
\text { Protective } \\
\text { Measure }\end{array}$ & $\begin{array}{l}\text { Hist. } \\
\text {.Inj. } \\
\text { (F/DI/NDI) }\end{array}$ & $\begin{array}{c}\text { Proj. } \\
\text { Inj } \\
(\mathrm{F} / \mathrm{DI} / \mathrm{NDI})\end{array}$ \\
\hline $\begin{array}{l}\text { Struck while setting } \\
\text { brattice. }\end{array}$ & 0 & 0 & N/A & $0 / 4 / 1$ & $0 / 0 / 0$ \\
\hline $\begin{array}{l}\text { Struck while drilling } \\
\text { face or rib. }\end{array}$ & 1 & 1 & Medi um & $0 / 3 / 0$ & $\begin{array}{l}\text { Less than } \\
0 / 3 / 0\end{array}$ \\
\hline $\begin{array}{l}\text { Operator or workers } \\
\text { pinched or struck by } \\
\text { shuttle car. }\end{array}$ & 0 & 0 & $\mathrm{~N} / \mathrm{A}$ & $1 / 174 / 3$ & $0 / 0 / 0$ \\
\hline $\begin{array}{l}\text { Pinched or struck get- } \\
\text { ting on or off, or } \\
\text { riding equipment. }\end{array}$ & 1 & 1 & N/A & $2 / 222 / 66$ & $2 / 222 / 66$ \\
\hline $\begin{array}{l}\text { Pinched or struck } \\
\text { while supervising. }\end{array}$ & 1 & 1 & N/A & $0 / 24 / 3$ & $0 / 24 / 3$ \\
\hline
\end{tabular}


Accident Class: Machinery

\begin{tabular}{|c|c|c|c|c|c|c|}
\hline Hazard/Activity & $\begin{array}{l}\text { Task } \\
\text { Time } \\
\text { Ratio }\end{array}$ & $\begin{array}{l}\text { Labor } \\
\text { Ratio }\end{array}$ & $\begin{array}{l}\text { Potential } \\
\text { Effect of } \\
\text { Protective } \\
\text { Measure }\end{array}$ & $\begin{array}{l}\text { Hist. } \\
\text { Inj } \\
(F / D I / N D I)\end{array}$ & $\begin{array}{l}\text { Proj. } \\
\text { Inj } \cdot \\
(\text { F/DI/NDI) }\end{array}$ & \\
\hline $\begin{array}{l}\text { Operator or helper } \\
\text { struck or pinched while } \\
\text { operating miner. }\end{array}$ & $\begin{array}{l}\text { Prot } \\
\text { meas }\end{array}$ & $\begin{array}{l}\text { ctive } \\
\text { re }\end{array}$ & Large & $0 / 94 / 34$ & $\begin{array}{l}\text { Much less } \\
0 / 94 / 34\end{array}$ & than \\
\hline $\begin{array}{l}\text { Workers struck by } \\
\text { machinery while doing } \\
\text { maintenance. }\end{array}$ & 0.9 & 1 & N/A & $1 / 49 / 21$ & $1 / 44 / 19$ & \\
\hline $\begin{array}{l}\text { Workers struck while } \\
\text { reeling or handling } \\
\text { cable. }\end{array}$ & 0 & 0 & $\mathrm{~N} / \mathrm{A}$ & $1 / 26 / 4$ & $0 / 0 / 0$ & e \\
\hline $\begin{array}{l}\text { Workers struck while } \\
\text { doing cleanup and using } \\
\text { handtools (i.e., not } \\
\text { maintenance). }\end{array}$ & 4 & 1 & Medium & $0 / 38 / 20$ & $\begin{array}{l}\text { Less than } \\
0 / 152 / 80 \\
\text {. }\end{array}$ & \\
\hline $\begin{array}{l}\text { Workers struck while } \\
\text { handling supplies. }\end{array}$ & 2 & 1.7 & $\mathrm{~N} / \mathrm{A}$ & $0 / 23 / 6$ & $0 / 78 / 20$ & \\
\hline $\begin{array}{l}\text { Struck while installing } \\
\text { temporary support. }\end{array}$ & 0 & 0 & N/A & $1 / 23 / 18$ & $0 / 0 / 0$ & \\
\hline $\begin{array}{l}\text { Workers caught or struck } \\
\text { while moving or operating } \\
\text { roof bolter. }\end{array}$ & 2.5 & 1 & Medium & $1 / 516 / 175$ & $\begin{array}{l}\text { Less than } \\
3 / 1290 / 438\end{array}$ & \\
\hline $\begin{array}{l}\text { Workers struck by other } \\
\text { machinery in area of } \\
\text { conveyor. }\end{array}$ & $\begin{array}{l}\text { Prot } \\
\text { meas }\end{array}$ & $\begin{array}{l}\text { ctive } \\
\text { re }\end{array}$ & Large & $1 / 10 / 2$ & $\begin{array}{l}\text { Much less } \\
1 / 10 / 2\end{array}$ & than \\
\hline $\begin{array}{l}\text { Workers struck while } \\
\text { riding or getting off } \\
\text { machinery. }\end{array}$ & 1 & 1 & N/A & $0 / 16 / 3$ & $0 / 16 / 3$ & \\
\hline $\begin{array}{l}\text { Struck while setting } \\
\text { brattice. }\end{array}$ & 0 & 0 & N/A & $0 / 14 / 1$ & $0 / 0 / 0$ & \\
\hline Struck while supervising. & 1 & 1 & N/A & $0 / 27 / 5$ & $0 / 27 / 5$ & \\
\hline
\end{tabular}


Accident Class: Machinery (Cont'd)

\begin{tabular}{|c|c|c|c|c|c|c|c|}
\hline Hazard/Activity & $\begin{array}{l}\text { Task } \\
\text { Time } \\
\text { Ratio }\end{array}$ & Labor & $\begin{array}{l}\text { Potential } \\
\text { Effect of } \\
\text { Protective } \\
\text { Measure }\end{array}$ & $\begin{array}{l}\text { Hist. } \\
\text { Inj } \\
(\mathrm{F} / \mathrm{DI} / \mathrm{NDI})\end{array}$ & $\begin{array}{l}\text { Proj. } \\
\text { Inj } \\
(\mathrm{F} / \mathrm{DI} / \mathrm{NDI})\end{array}$ & $\therefore$ & . \\
\hline $\begin{array}{l}\text { Struck by other machinery } \\
\text { while operating rail } \\
\text { cars. }\end{array}$ & 1 & 1 & $\mathbf{N} / \mathbf{A}$ & $0 / 4 / 1$ & $0 / 4 / 1$ & & \\
\hline $\begin{array}{l}\text { Struck by other machinery } \\
\text { while operating shuttle } \\
\text { cars. }\end{array}$ & 0 & 0 & N/A & $1 / 56 / 17$ & $0 / 0 / 0$ & & . \\
\hline $\begin{array}{l}\text { Tunneling industry data } \\
\text { (given in injuries per } \\
\text { million manhours). }\end{array}$ & & $\cdot$ & & & . & & . \\
\hline $\begin{array}{l}\text { Struck or caught while } \\
\text { moving or operating } \\
\text { large drills. }\end{array}$ & 1 & 1 & N/A & $0 / 8 / 3$ & $0 / 8 / 3$ & & . \\
\hline $\begin{array}{l}\text { Caught while operating } \\
\text { or unclogging shotcrete } \\
\text { machinery. }\end{array}$ & 1 & 1 & N/A & $0 / 5 / 14$ & $0 / 5 / 14$ & & . \\
\hline $\begin{array}{l}\text { Caught while maintaining } \\
\text { shotcrete machinery. }\end{array}$ & 1 & 1 & N/A & $0 / 3 / 1$ & $0 / 3 / 1$ & & \\
\hline $\begin{array}{l}\text { Struck or caught while } \\
\text { operating hoists. }\end{array}$ & 1 & 1 & N/A & $0 / 2 / 1$ & $0 / 2 / 1$ & & \\
\hline
\end{tabular}


Accident Class: Handling Materials

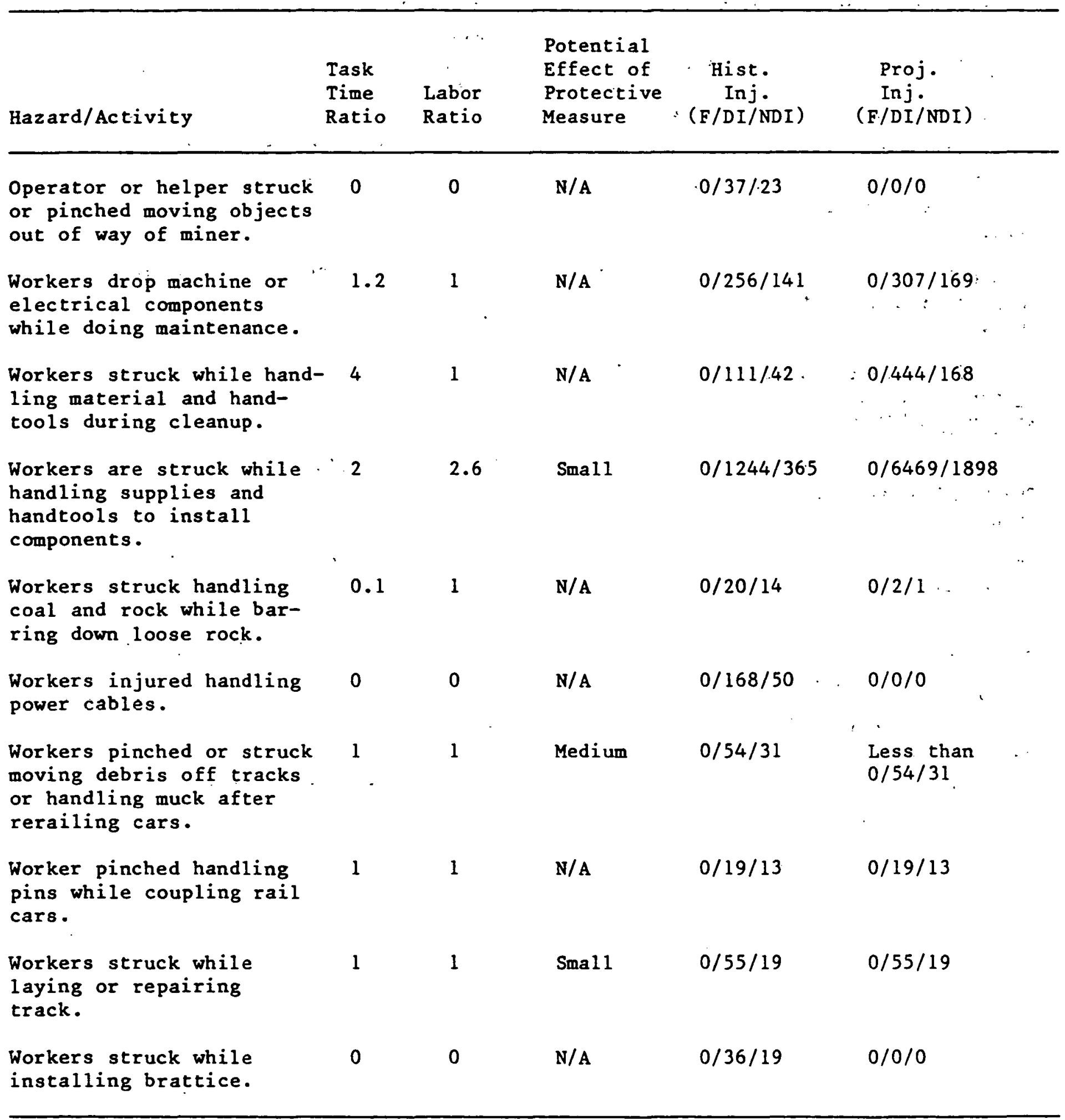


Accident Class: Handling Materials (Cont'd)

\begin{tabular}{|c|c|c|c|c|c|}
\hline Hazard/Activity & $\begin{array}{l}\text { Task } \\
\text { Time } \\
\text { Ratio }\end{array}$ & $\begin{array}{l}\text { Labor } \\
\text { Ratio }\end{array}$ & $\begin{array}{l}\text { Potential } \\
\text { Effect of } \\
\text { Protective } \\
\text { Measure }\end{array}$ & $\begin{array}{l}\text { Hist. } \\
\text { Inj } . \\
\text { (F/DI/NDI) }\end{array}$ & $\begin{array}{l}\text { Proj : } \\
\text { Inj } \\
(\mathrm{F} / \mathrm{DI} / \mathrm{NDI})\end{array}$ \\
\hline $\begin{array}{l}\text { Workers drop materials } \\
\text { while walking or } \\
\text { running. }\end{array}$ & 1 & 1 & $\mathbf{N} / \mathbf{A}$ & $0 / 24 / 16$ & $0 / 24 / 16$ \\
\hline $\begin{array}{l}\text { Workers drop drill } \\
\text { section while drilling } \\
\text { face or rib. }\end{array}$ & 1 & 1 & N/A & $\begin{array}{c}0 / 10 / 15 \\
.\end{array}$ & $0 / 10 / 15$ \\
\hline $\begin{array}{l}\text { Workers pinched while } \\
\text { moving debris away from } \\
\text { shuttle car. }\end{array}$ & 0 & 0 & N/A & $0 / 62 / 46$ & $0 / 0 / 0$ \\
\hline $\begin{array}{l}\text { Struck while supervising } \\
\text { or during accident } \\
\text { recovery. }\end{array}$ & 1 & 1 & Sma11 & $0 / 43 / 44$ & $0 / 43 / 44$ \\
\hline
\end{tabular}


Accident Class: Explosion/Fire

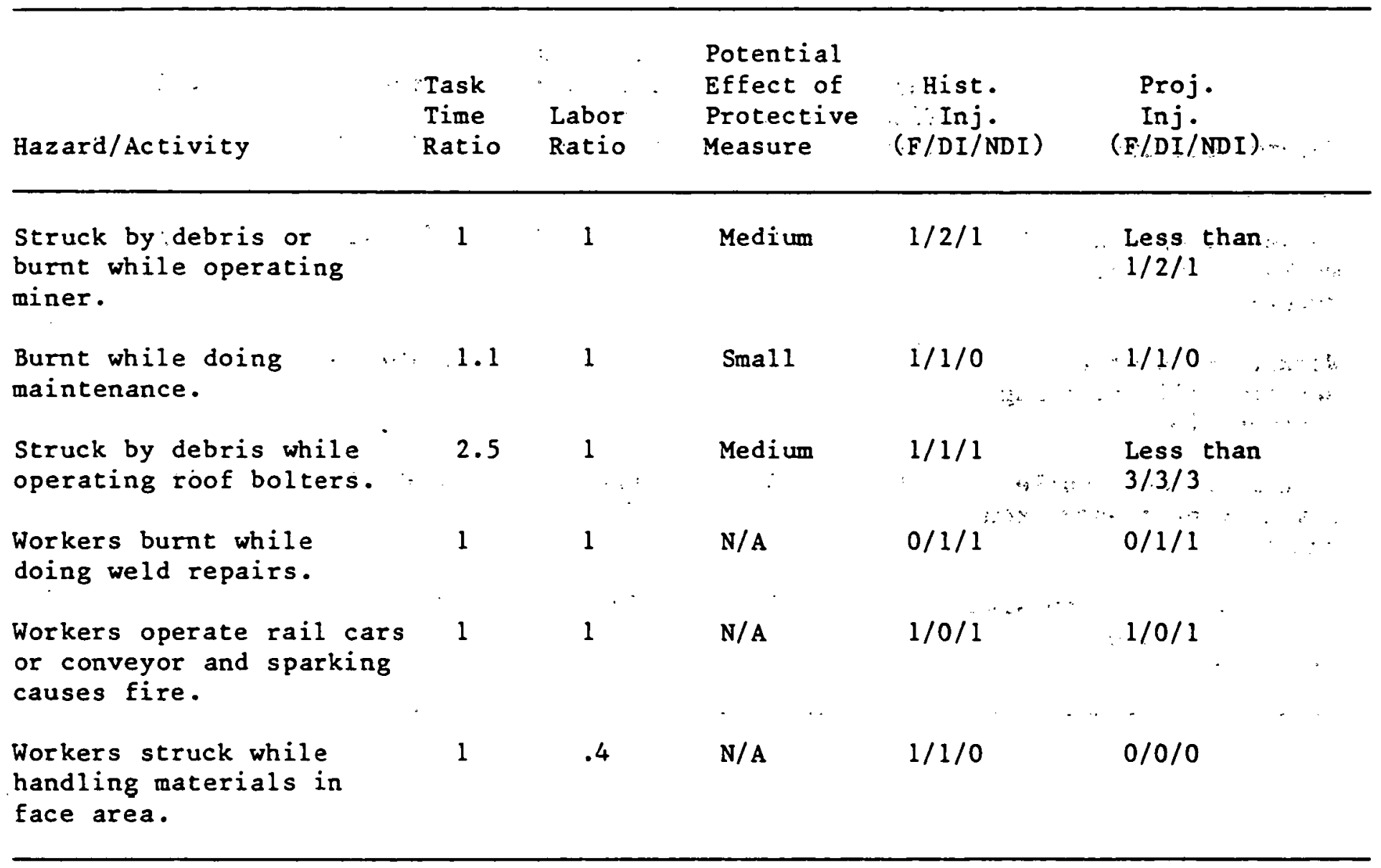




\begin{tabular}{|c|c|c|c|c|c|c|}
\hline Hazard/Activity & $\begin{array}{l}\text { Task } \\
\text { Time } \\
\text { Ratio }\end{array}$ & $\begin{array}{l}\text { Labor } \\
\text { Ratio }\end{array}$ & $\begin{array}{l}\text { Potential } \\
\text { Effect of } \\
\text { Protective } \\
\text { Measure }\end{array}$ & $\begin{array}{l}\text { Hist. } \\
\text { Inj } \\
(\mathrm{F} / \mathrm{DI} / \mathrm{NDI})\end{array}$ & $\begin{array}{l}\text { Proj } \\
\text { Inj } \\
(F / D I / N D I)\end{array}$ & \\
\hline $\begin{array}{l}\text { Operator or helper come } \\
\text { in contact with energized } \\
\text { conductor while operating } \\
\text { miner. }\end{array}$ & 1 & 0.5 & N/A & $0 / 3 / 1$ & $0 / 2 / 1$ & \\
\hline $\begin{array}{l}\text { Workers contact energized } \\
\text { conductor while perform- } \\
\text { ing machine or electrical } \\
\text { maintenance. }\end{array}$ & 1.1 & 1 & N/A & $2 / 67 / 25$ & $2 / 74 / 28$ & \\
\hline $\begin{array}{l}\text { Workers are tramming or } \\
\text { moving equipment and } \\
\text { contact energized cable. }\end{array}$ & 0.8 & 1 & Medium & $1 / 10 / 4$ & $\begin{array}{l}\text { Less than } \\
1 / 8 / 3\end{array}$ & \\
\hline $\begin{array}{l}\text { Workers contact trolley } \\
\text { wire getting on and off } \\
\text { equipment. }\end{array}$ & 0 & 1 & N/A & $0 / 10 / 14$ & $0 / 0 / 0$ & \\
\hline $\begin{array}{l}\text { Workers contact energized } \\
\text { cable while performing } \\
\text { cleanup. }\end{array}$ & 3.4 & 1 & Sma11 & $0 / 2 / 0$ & $0 / 7 / 0$ & \\
\hline $\begin{array}{l}\text { Workers are handling } \\
\text { metal supplies and con- } \\
\text { tact energized conductor. }\end{array}$ & 0.9 & 1.7 & Sma11 & $1 / 10 / 2$ & $2 / 15 / 3$ & \\
\hline $\begin{array}{l}\text { Workers contact energized } \\
\text { cable while handling or } \\
\text { reeling cable. }\end{array}$ & 0 & 0 & N/A & $1 / 10 / 4$ & $0 / 0 / 0$ & \\
\hline $\begin{array}{l}\text { Workers are using conduc- } \\
\text { ting handtools and } \\
\text { contact energized conductor } \\
\text { (not maintenance). }\end{array}$ & 1.9 & 3 & Sma11 & $0 / 2 / 4$ & $0 / 11 / 23$ & \\
\hline $\begin{array}{l}\text { Workcre contact energized } \\
\text { conductor while operating } \\
\text { or rerailing rail cars. }\end{array}$ & 1 & 1 & N/A & $0 / 16 / 7$ & $0 / 16 / 7$ & \\
\hline $\begin{array}{l}\text { Workers perform weld } \\
\text { repairs and are burnt } \\
\text { or shocked by arc. }\end{array}$ & 1 & 1 & N/A & $0 / 4 / 1$ & $0 / 4 / 1$ & \\
\hline
\end{tabular}




\begin{tabular}{|c|c|c|c|c|c|}
\hline Hazard/Activity & $\begin{array}{l}\text { Task } \\
\text { Time } \\
\text { Ratio }\end{array}$ & $\begin{array}{l}\text { Labor } \\
\text { Ratio, }\end{array}$ & $\begin{array}{l}\text { Potential } \\
\text { Effect of } \\
\text { Protective } \\
\text { Measure }\end{array}$ & $\begin{array}{l}\text { Hist. } \\
\text { Inj } \cdot \\
(\mathrm{F} / \mathrm{DI} / \mathrm{NDI})\end{array}$ & $\begin{array}{l}\text { Proj. } \\
\text { Inj } \\
(F / D I / N D I)\end{array}$ \\
\hline $\begin{array}{l}\text { Workers slip and fall } \\
\text { while drilling face or } \\
\text { rib, or moving drill. }\end{array}$ & 1 & 1 & N/A & $0 / 12 / 5$ & $0 / 12 / 5$ \\
\hline $\begin{array}{l}\text { Slip while barring } \\
\text { down loose rack. }\end{array}$ & 0.1 & 1 & N/A & $0 / 8 / 3$ & $0 / 1 / 0$ \\
\hline $\begin{array}{l}\text { Slip and fall while } \\
\text { operating miner. }\end{array}$ & $\begin{array}{l}\text { Prot } \\
\text { meas }\end{array}$ & $\begin{array}{l}\text { ctive } \\
\text { re }\end{array}$ & Large & $0 / 11 / 5$ & $\begin{array}{l}\text { Much less than } \\
0 / 11 / 5\end{array}$ \\
\hline $\begin{array}{l}\text { slip and fall while } \\
\text { moving or operating } \\
\text { other machinery. }\end{array}$ & 4.2 & 1.7 & $\mathbf{N} / \mathbf{A}$ & $0 / 47 / 17$ & $0 / 334 / 121$ \\
\hline $\begin{array}{l}\text { Slip and fall while } \\
\text { doing cleanup. }\end{array}$ & 4 & 1 & Sma 11 & $0 / 30 / 8$ & $0 / 120 / 32$ \\
\hline $\begin{array}{l}\text { Slip and fall off } \\
\text { machinery while doing } \\
\text { maintenance. }\end{array}$ & 1.2 & 1 & Small & $0 / 60 / 20$ & $0 / 72 / 24$ \\
\hline $\begin{array}{l}\text { Slip and fall handling } \\
\text { awkward supplies. }\end{array}$ & 2 & 2.6 & Small & $0 / 116 / 22$ & $0 / 603 / 114$ \\
\hline $\begin{array}{l}\text { Slip and fall while } \\
\text { cable reeling. }\end{array}$ & 0 & 0 & N/A & $0 / 35 / 8$ & $0 / 0 / 0$ \\
\hline $\begin{array}{l}\text { Slip and fall while } \\
\text { working with handtools } \\
\text { (not maintenance). }\end{array}$ & 1.6 & 1.7 & Small & $0 / 28 / 11$ & $0 / 76 / 30$ \\
\hline $\begin{array}{l}\text { Slip and fall laying } \\
\text { and repairing track. }\end{array}$ & 1 & 1 & Sma11 & $0 / 12 / 1$ & $0 / 12 / 1$ \\
\hline $\begin{array}{l}\text { slip and fall while } \\
\text { operating or articulating } \\
\text { conveyor. }\end{array}$ & \multicolumn{2}{|c|}{$\begin{array}{l}\text { Protective } \\
\text { measure }\end{array}$} & Large & $0 / 22 / 6$ & $\begin{array}{l}\text { Much less than } \\
0 / 22 / 6\end{array}$ \\
\hline
\end{tabular}


Accident Class: Slip and Fall (Cont'd)

\begin{tabular}{|c|c|c|c|c|c|}
\hline Hazard/Activity & $\begin{array}{l}\text { Task } \\
\text { Time } \\
\text { Ratio }\end{array}$ & $\begin{array}{l}\text { Labor } \\
\text { Ratio }\end{array}$ & $\begin{array}{l}\text { Potential } \\
\text { Effect of } \\
\text { Protective } \\
\text { Measure }\end{array}$ & $\begin{array}{l}\text { Hist. } \\
\text { Inj . } \\
(\mathrm{F} / \mathrm{DI} / \mathrm{NDI})\end{array}$ & $\begin{array}{l}\text { Proj. } \\
\text { Inj } \\
(F / D I / N D I)\end{array}$ \\
\hline $\begin{array}{l}\text { Slip and fall operating } \\
\text { locomotive, rerailing } \\
\text { equipment, getting on } \\
\text { or off equipment, riding } \\
\text { equipment, coupling rail } \\
\text { cars, spotting cars. }\end{array}$ & 1 & 1 & N/A & $0 / 118 / 49$ & $0 / 118 / 49$ \\
\hline $\begin{array}{l}\text { slip and fall setting } \\
\text { or removing props. }\end{array}$ & 0.1 & 1 & N/A & $0 / 16 / 4$ & $0 / 2 / 0$ \\
\hline $\begin{array}{l}\text { slip and fall while } \\
\text { setting brattice. }\end{array}$ & 0 & 0 & N/A & $0 / 14 / 4$ & $0 / 0 / 0$ \\
\hline $\begin{array}{l}\text { Slip and fall escaping } \\
\text { a hazard or while } \\
\text { supervising. }\end{array}$ & 1 & 1 & Sma11 & $0 / 278 / 89$ & $0 / 278 / 89$ \\
\hline
\end{tabular}


Accident Class: Handtools

\begin{tabular}{|c|c|c|c|c|c|}
\hline Hazard/Activity & $\begin{array}{l}\text { Task } \\
\text { Time } \\
\text { Ratio }\end{array}$ & Labor & $\begin{array}{l}\text { Potential } \\
\text { Effect of } \\
\text { Protective } \\
\text { Measure }\end{array}$ & $\begin{array}{l}\text { Hist. } \\
\text { Inj } \\
\text { (F/DI/NDI) }\end{array}$ & $\begin{array}{l}\text { Proj. } \\
\text { Inj } \\
(F / D I / N D I)\end{array}$ \\
\hline $\begin{array}{l}\text { Struck while widening } \\
\text { the entry. }\end{array}$ & 0 & 0 & N/A & $0 / 1 / 1$ & $0 / 0 / 0$ \\
\hline $\begin{array}{l}\text { Struck while barring } \\
\text { down face and rib. }\end{array}$ & 0.1 & 1 & N/A & $0 / 12 / 6$ & $0 / 1 / 1$ \\
\hline $\begin{array}{l}\text { Struck by tool while } \\
\text { performing cleanup. }\end{array}$ & 4 & 1 & N/A & $0 / 5 / 4$ & $0 / 20 / 16$ \\
\hline $\begin{array}{l}\text { Tool slips or breaks } \\
\text { while performing } \\
\text { maintenance. }\end{array}$ & 1.2 & 1 & N/A & $0 / 55 / 50$ & $0 / 66 / 60$ \\
\hline $\begin{array}{l}\text { Handtools slip or break } \\
\text { while being used (not } \\
\text { maintenance, cleanup, } \\
\text { or setting temporary } \\
\text { support); mostly outby } \\
\text { support. }\end{array}$ & 2.3 & 3 & N/A & $0 / 277 / 331$ & $0 / 1911 / 2284$ \\
\hline $\begin{array}{l}\text { Struck while laying or } \\
\text { repairing track. }\end{array}$ & 1 & 1 & N/A & $0 / 8 / 5$ & $0 / 8 / 5$ \\
\hline $\begin{array}{l}\text { Tool slips while handling } \\
\text { supplies. }\end{array}$ & 2 & 2.6 & N/A & $0 / 13 / 8$ & $0 / 68 / 42$ \\
\hline $\begin{array}{l}\text { Struck while coupling } \\
\text { cars or rerailing cars. }\end{array}$ & 1 & 1 & N/A & $0 / 17 / 8$ & $0 / 17 / 8$ \\
\hline $\begin{array}{l}\text { Struck while tightening } \\
\text { drills. }\end{array}$ & 5.8 & 1 & N/A & $0 / 6 / 8$ & $0 / 35 / 46$ \\
\hline $\begin{array}{l}\text { Tool slips or breaks } \\
\text { while setting props or } \\
\text { timber. }\end{array}$ & 0.1 & 1 & N/A & $0 / 32 / 17$ & $0 / 3 / 2$ \\
\hline $\begin{array}{l}\text { Struck while setting } \\
\text { brattice. }\end{array}$ & 0 & 0 & N/A & $0 / 4 / 4$ & $0 / 0 / 0$ \\
\hline $\begin{array}{l}\text { Tool slips while adjust- } \\
\text { ing conveyor, spill } \\
\text { pans, etc. }\end{array}$ & 1 & 1 & N/A & $0 / 0 / 1$ & $0 / 0 / 1$ \\
\hline $\begin{array}{l}\text { Supervisor struck by } \\
\text { tool. }\end{array}$ & 1 & 1 & $\mathrm{~N} / \mathrm{A}$ & $0 / 4 / 4$ & $0 / 4 / 4$ \\
\hline
\end{tabular}


Accident Class: Pressure Release

\begin{tabular}{|c|c|c|c|c|c|c|}
\hline Hazard/Activity & $\begin{array}{l}\text { Task } \\
\text { Time } \\
\text { Ratio }\end{array}$ & $\begin{array}{l}\text { Labor } \\
\text { Ratio }\end{array}$ & $\begin{array}{l}\text { Potential } \\
\text { Effect of } \\
\text { Protective } \\
\text { Measure }\end{array}$ & $\begin{array}{c}\text { Hist. } \\
\text { Inj - } \\
\text { (F/DI/NDI) }\end{array}$ & $\begin{array}{l}\text { Proj. } \\
\text { Inj } \\
(\mathrm{F} / \mathrm{DI} / \mathrm{NDI})\end{array}$ & . \\
\hline $\begin{array}{l}\text { Struck by whipping } \\
\text { hydraulic line while } \\
\text { doing maintenance. }\end{array}$ & 1.3 & 1 & N/A & $0 / 2 / 1$ & $0 / 3 / 1$ & \\
\hline $\begin{array}{l}\text { Struck by pressure } \\
\text { release from failed } \\
\text { hydraulic jack. }\end{array}$ & 1 & 1 & $\mathrm{~N} / \mathrm{A}$ & $0 / 0 / 1$ & $0 / 0 / 1$ & \\
\hline $\begin{array}{l}\text { Tunneling industry } \\
\text { experience (given in } \\
\text { injuries per million } \\
\text { manhours). }\end{array}$ & & & $\cdot$ & & & \\
\hline $\begin{array}{l}\text { Struck by pneumatic } \\
\text { lines, or fittings } \\
\text { while operating } \\
\text { equipment. }\end{array}$ & 1 & 1 & $\mathrm{~N} / \mathrm{A}$ & $* 0 / 6 / 0$ & $0 / 6 / 0$ & 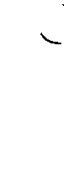 \\
\hline
\end{tabular}

*Injuries per million manhours. 


\section{APPENDIX B \\ DETAILED INJURY ADJUSTMENTS BY \\ GROUP OF EXPERTS, BY ACCIDENT \\ CLASS AND HAZARD}

B-1 
THIS PAGE

\section{WAS INTENTIONALLY LEFT BLANK}




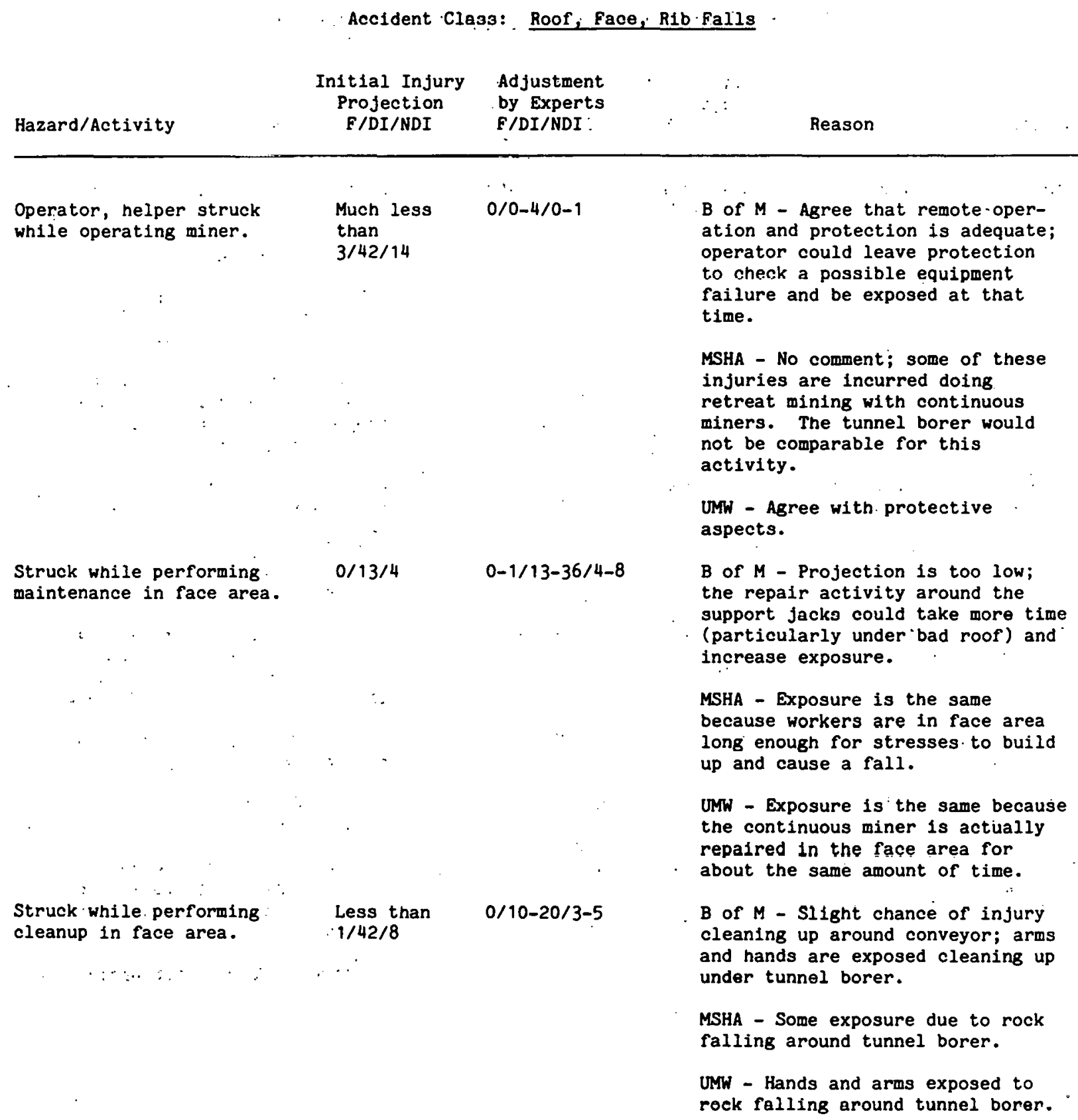


Accident Class: Roof, Face, Rib Falls (Continuation 1)

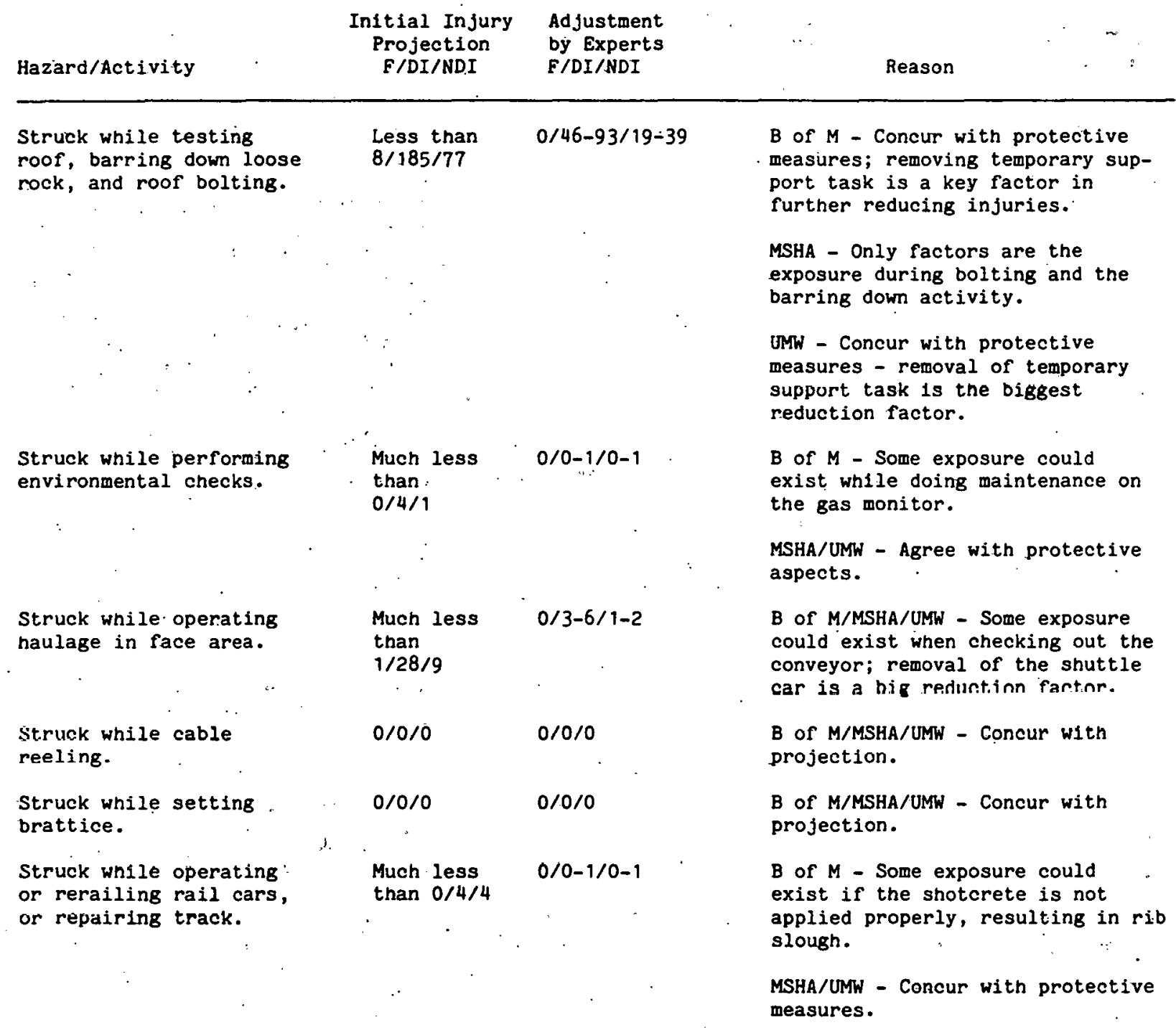


Accident Class: Roof, Face, Rib Falls (Continuation 2)

\begin{tabular}{|c|c|c|c|}
\hline Hazard/Activity & $\begin{array}{l}\text { Initial Injury } \\
\text { Projection } \\
\text { F/DI/NDI }\end{array}$ & $\begin{array}{l}\text { Adjustment } \\
\text { by Experts } \\
\text { F/DI/NDI }\end{array}$ & Reason \\
\hline $\begin{array}{l}\text { Struck while escaping } \\
\text { a hazard or during } \\
\text { accident recovery. }\end{array}$ & $\begin{array}{l}\text { Less than } \\
2 / 7 / 2\end{array}$ & . & $\begin{array}{l}\text { B of } M \text { - Most workers are } \\
\text { protected; some exposure } \\
\text { exists if accident occurs during } \\
\text { maintenance at the face. } \\
\text { MSHA/UMW - Some exposure exists } \\
\text { during the cutterhead maintenance } \\
\text { activity. }\end{array}$ \\
\hline $\begin{array}{l}\text { Struck while riding } \\
\text { equipment to face area. }\end{array}$ & $\begin{array}{l}\text { Much less } \\
\text { than } \\
0 / 5 / 3\end{array}$ & $0 / 0 / 0$ & $\begin{array}{l}\text { B of M/MSHA/UMW - Concur with } \\
\text { protective measures.: }\end{array}$ \\
\hline Struck while supervising. & $\begin{array}{l}2 / 44 / 11 \\
:\end{array}$ & $2 / 44 / 11$ & $\begin{array}{l}\text { B of M/MSHA/UMW - Concur with } \\
\text { projection; supervisors are always } \\
\text { the first people to take risks } \\
\text { while investigating problems. }\end{array}$ \\
\hline
\end{tabular}


Accident Class: Haulage

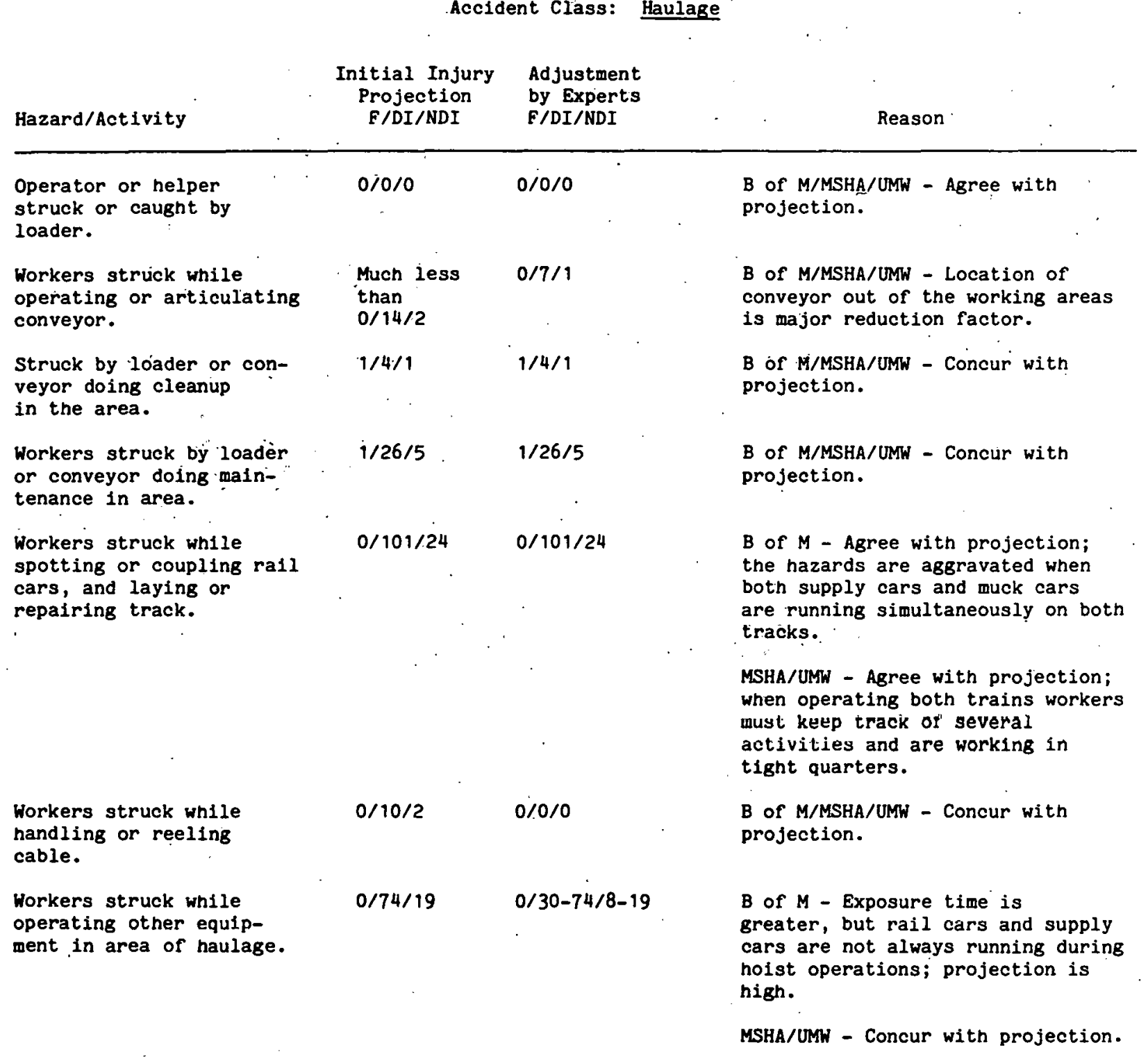




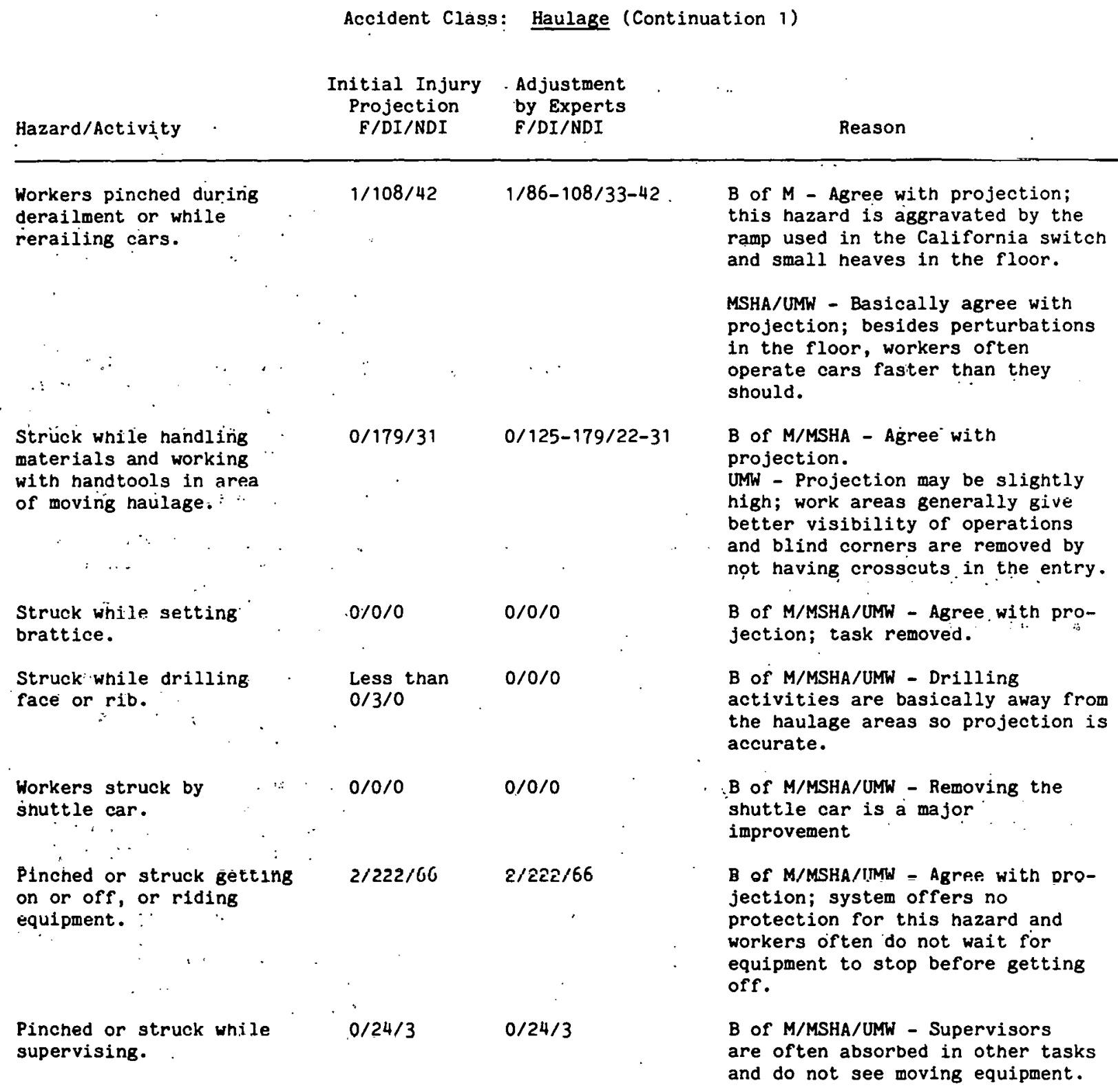




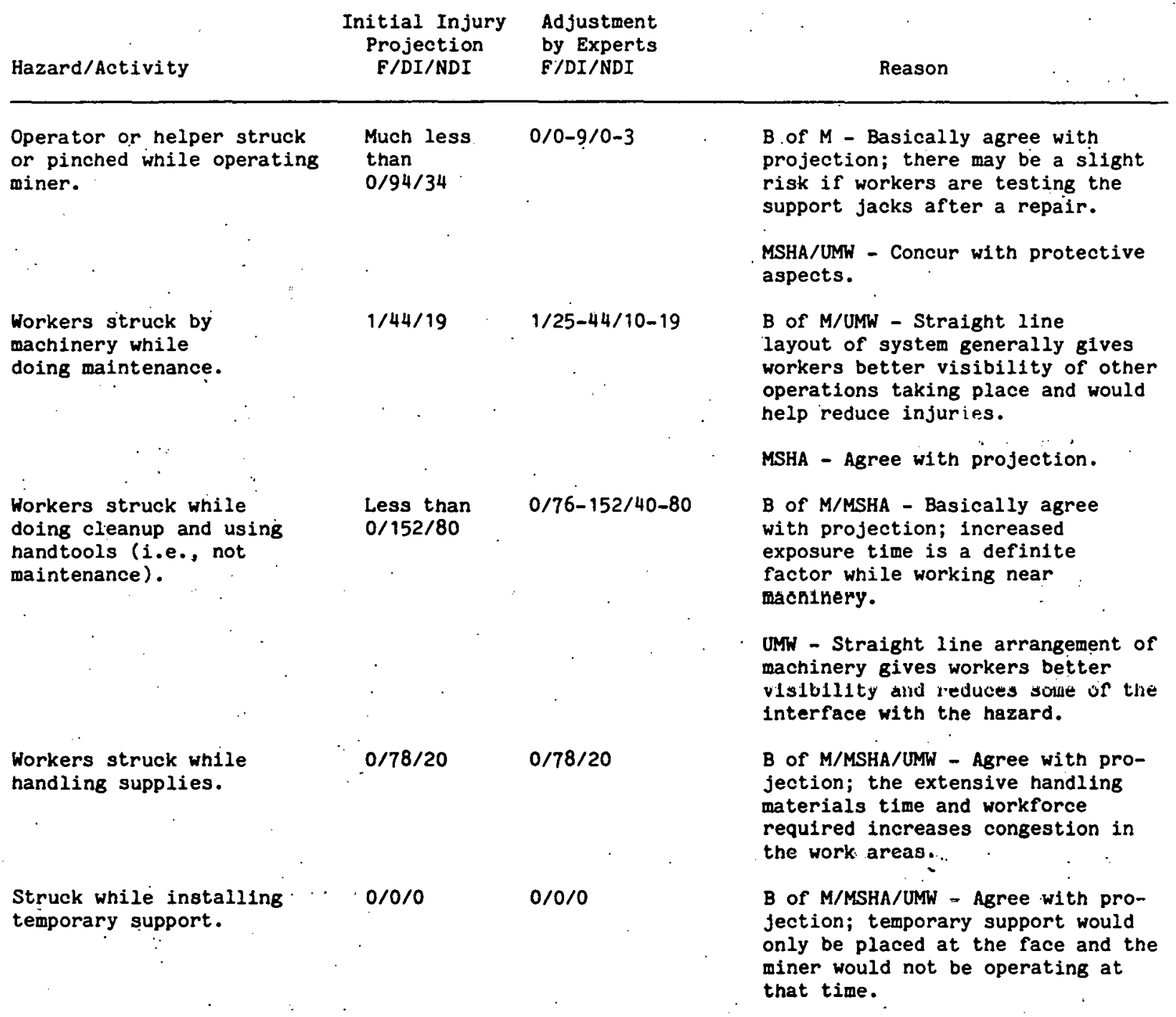




\begin{tabular}{|c|c|c|}
\hline & Accident Class: & Machinery (Continuation 1 ) \\
\hline Jazard/Activity & $\begin{array}{l}\text { Initial Injury } \\
\text { Projection } \\
\text { F/DI/NDI }\end{array}$ & $\begin{array}{l}\text { Adjustment } \\
\text { by Experts } \\
\text { F/DI/NDI }\end{array}$ \\
\hline
\end{tabular}

Workers caught or struck while moving or operating roof bolters.
Less than $3 / 1290 / 438$

$0 / 516-645 / 219-438$

B of M - Fatalities are generally caused by workers belng struck by the bolter while moving or tramming; the bolters on the tunnel borer are not as massive and are constrained in their movement - this would alleviate fatalities. Since the bolting procedure is simpler, workers have less variables to worry about; this would offset the exposure time and reduce disabling injuries.

MSHA/UMW - The constrained movement offsets the increased exposure time.

B of M/MSHA/UMW - The removal of the conveyor from the working area completely offsets this hazard.

machinery in the area

Much less

$0 / 0 / 0$

than

of the conveyor.

$0 / 16 / 3$

$0 / 8 / 1$

Workers struck while riding or getting off machinery.

\section{Struck while setting}

$0 / 0 / 0$

$0 / 27 / 5$

Struck while supervising.

$0 / 0 / 0$

$0 / 0 / 0$

Struck by other machinery while operating shuttle cars.

Struck or caught while operating large drills, shotcrete machinery, or hoists.

- $0 / 18 / 19 \quad 0 / 18 / 19$

B of M/MSHA/UMW - Horkers generally have better visibility of operations with the straight line layout of equipment.

B of M/MSHA/UMW - Concur with projection; task is removed.

B of M/MSHA/UMW - Concur w1th projection; supervisors are often absorbed in problems and do not see hazard.

B of M/MSHA/UMW - Removal of the shuttle oar is an important factor.

B of M/MSHA/UMW - Agree with tunneling industry data; system does not mitigate these hazards.

- Injuries per million manhours. 
Accident Class: Handling Materiais

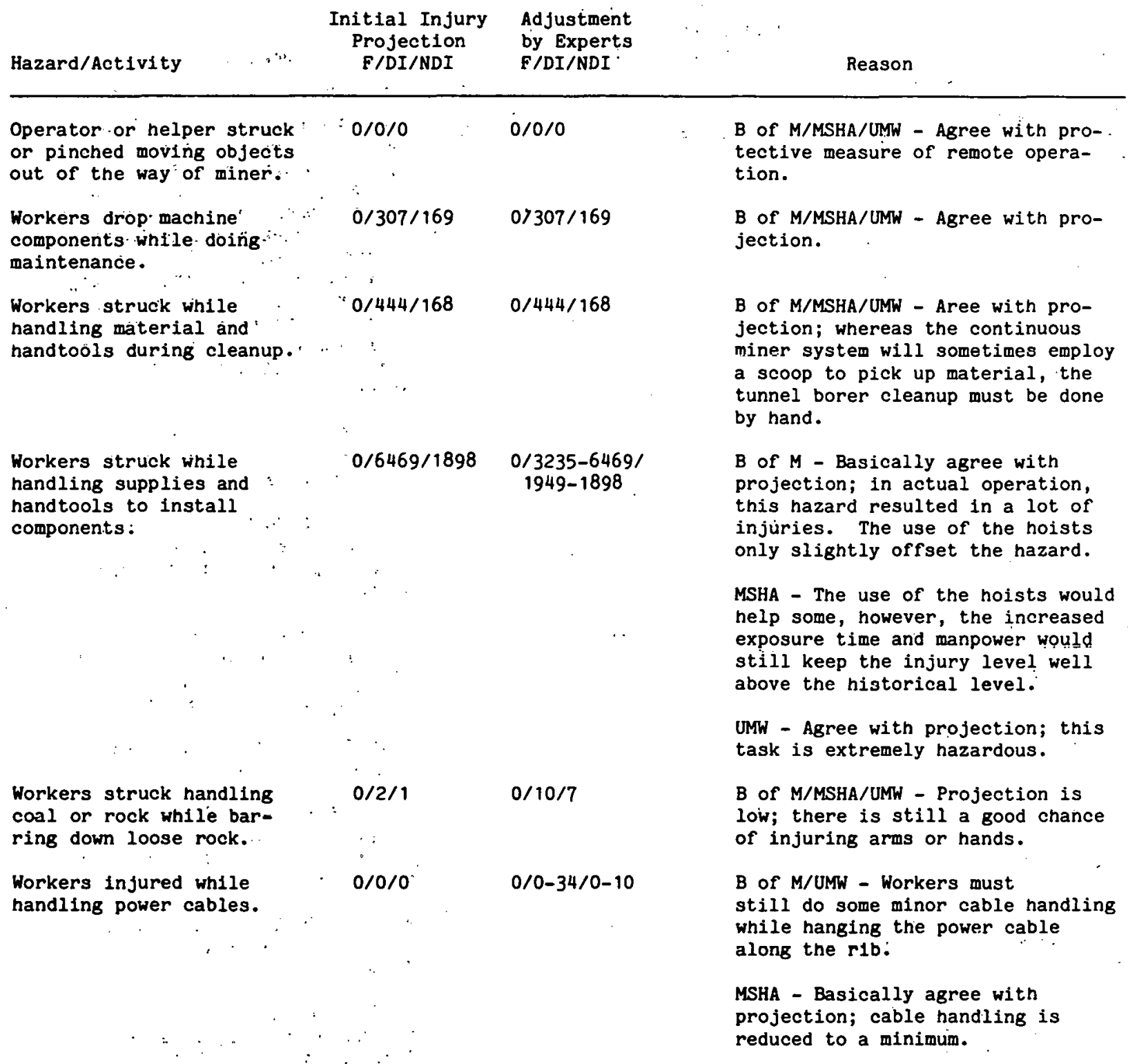


Accident Class: Handling Materials (Continuation 1)

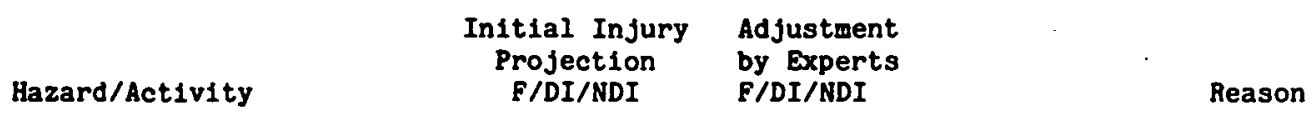

\begin{tabular}{|c|c|c|c|}
\hline $\begin{array}{l}\text { Workers pinched or struck } \\
\text { moving debris off tracks, } \\
\text { or handling muck after } \\
\text { reralling cars. }\end{array}$ & $\begin{array}{l}\text { Less than } \\
0 / 54 / 31\end{array}$ & $0 / 5-27 / 3-16$ & $\begin{array}{l}\text { B of M/MSHA - The shotcrete } \\
\text { lining helps prevent rib slough; } \\
\text { still some exposure exists since } \\
\text { derailments can occur due to floor } \\
\text { heave, or the ramp at the } \\
\text { California switch. }\end{array}$ \\
\hline & & . & $\begin{array}{l}\text { UMW - Some exposure still exists } \\
\text { if the shotcrete is not applied } \\
\text { properly, allowing rib slough; } \\
\text { derailments can st1ll occur due to } \\
\text { bumps in the floor. }\end{array}$ \\
\hline
\end{tabular}

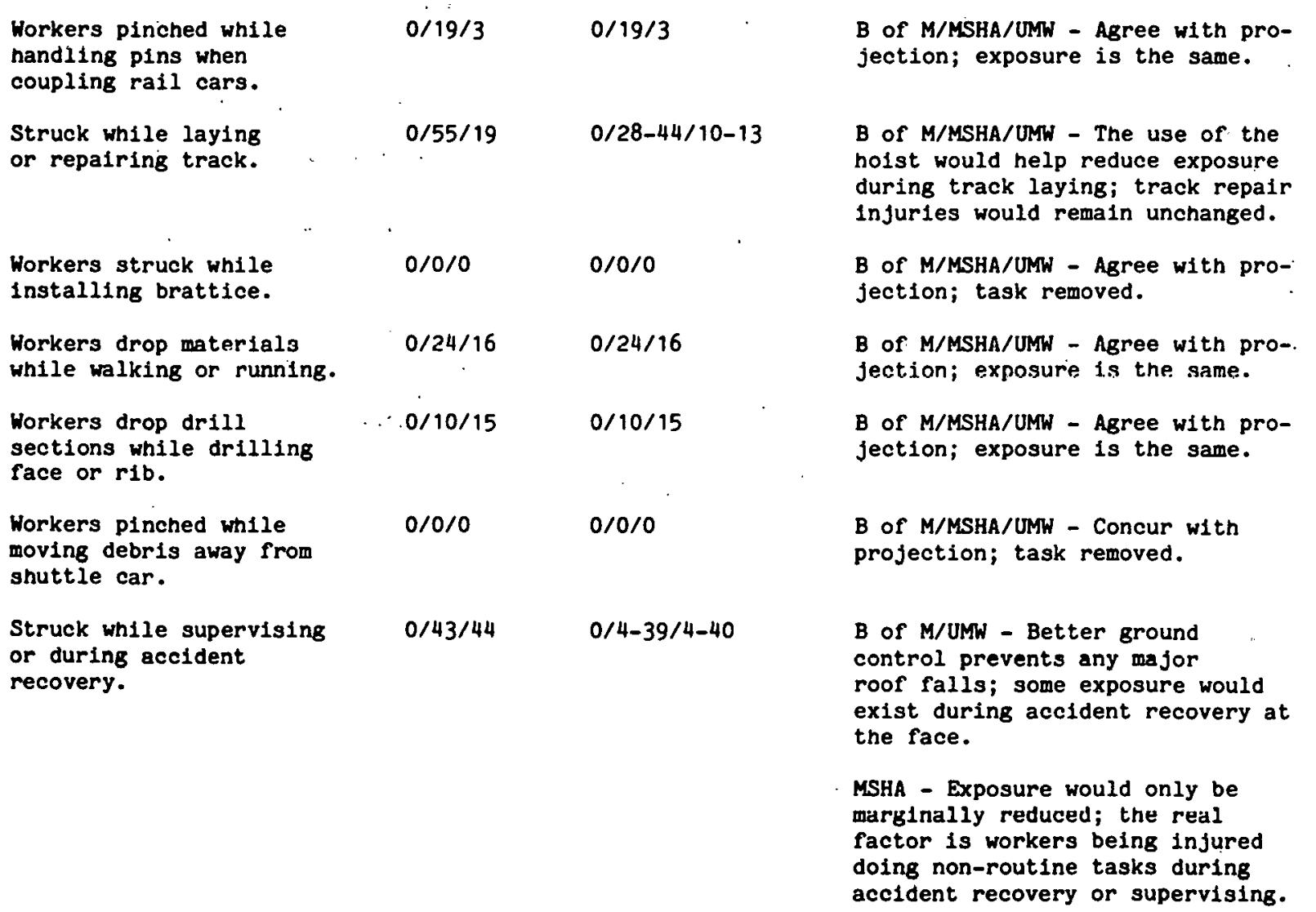




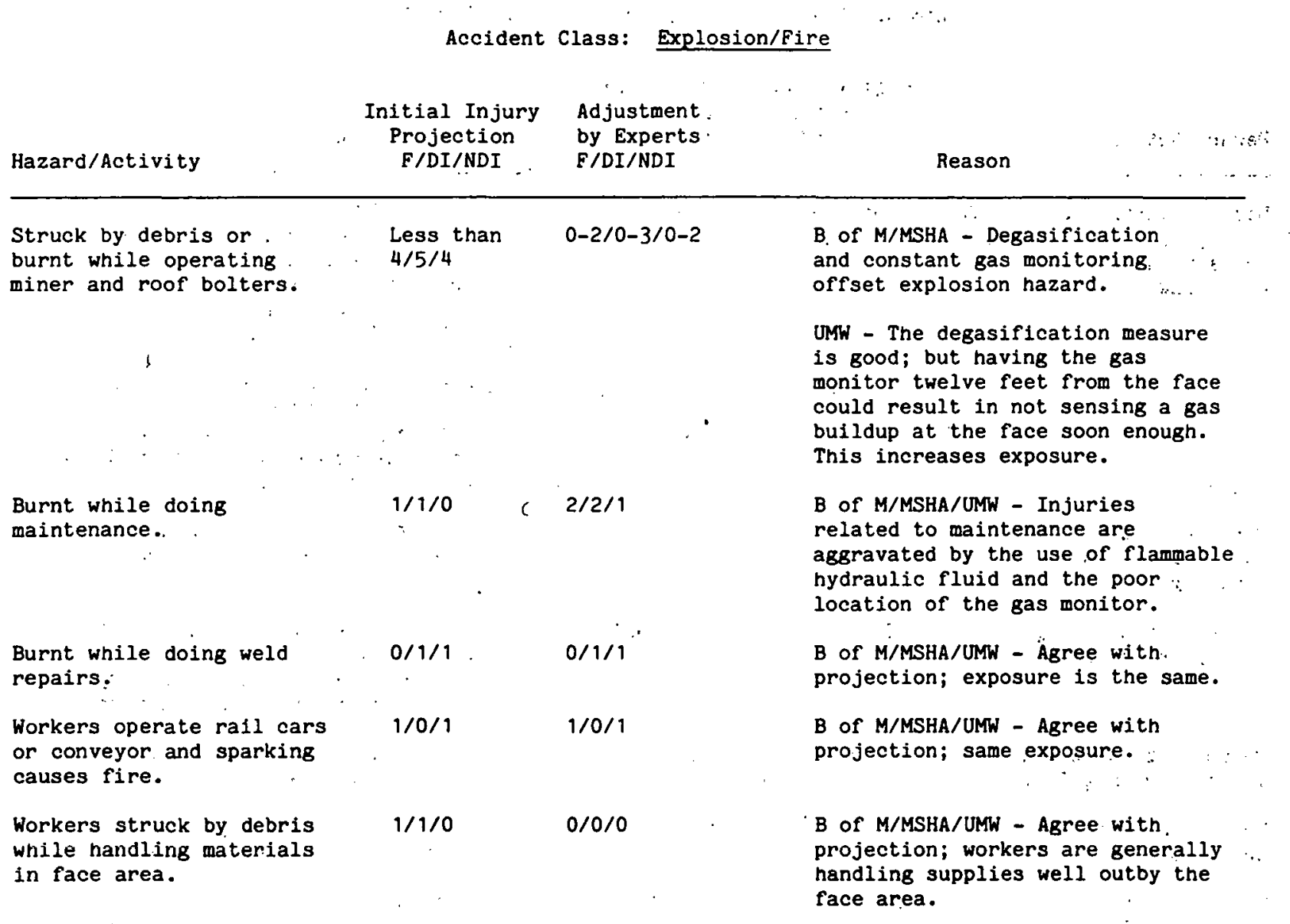




$\begin{array}{ccc}\text { Initial Injury } & \text { Adjustment } \\ \text { Projection } & \text { by Experts } \\ \text { Hazard/Activity } & \text { F/DI/NDI } & \text { F/DI/NDI }\end{array}$

Operator, helper come in contact with energized conductor while operating miner.

Workers contact energized conductior while performing maintenance.

\section{$0 / 2 / 1$}

$0 / 1-3 / 0-1$
Workers are moving or tramming equipment and contact frayed cable.

Workers contact trolley wire getting on and off equipment.

Workers contact energized cable while performing cleanup.

Workers are handling metal supplies and contact energized conductor; workers contact energized conductor using handtools (not maintenance).
Reason
$B$ of M/UMW - Exposure is reduced by firmly attaching electrical components to the control room skid; this reduces the movement of cables, which prevents breakage at the terminals.

MSHA - Exposure is basically the same; workers must still clean terminals.

B of M/MSHA - Agree with projection; exposure to. electrical injuries is greater due to larger amount of maintenance time.

UMW - Exposure is actually the same as the continuous miner system because there are more cables and power distribution boxes associated with the continuous miner.

B of M/MSHA/UMW - Removal of cable from the work areas and the layout of equipment reduces exposurè considerably.

B of M/MSHA/UMW - Agree with projection; trolley wire removed.

B of M/MSHA/UMH - Though cleanup time is greater, removal of the main power cable from the working area and reduced cable handling allows workers to know where. cables are located at. all times.

B of M/MSHA/UMW - Concur with projection; the cable can be damaged by the hoist activities. Ine greater exposure time and workforce also contribute to increasing exposure. 


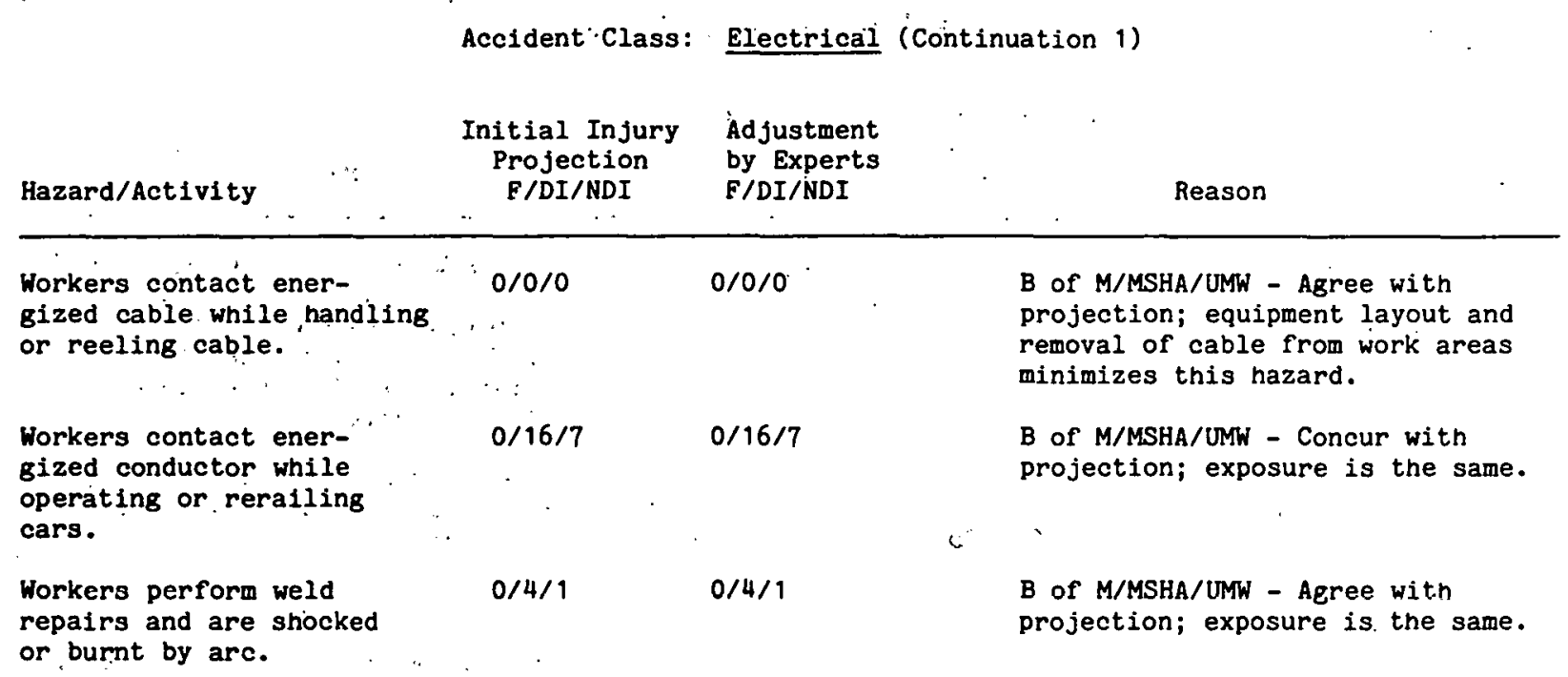


Accident Class: Slip and Fall

\begin{tabular}{|c|c|c|c|}
\hline Hazard/Activity & $\begin{array}{l}\text { Initial Injury } \\
\text { Projection } \\
\text { F/DI/NDI }\end{array}$ & $\begin{array}{l}\text { Adjustment } \\
\text { by Experts } \\
\text { F/DI/NDI }\end{array}$ & Reason \\
\hline $\begin{array}{l}\text { Workers slip and fall } \\
\text { while drilling face or } \\
\text { rib, or moving drijl. }\end{array}$ & $0 / 12 / 5$ & $0 / 12-15 / 5-6$ & $\begin{array}{l}\text { B of } M \text { - There is slightly more } \\
\text { drilling activity with the tunnel } \\
\text { borer system; this stems from the } \\
\text { use of roof bolts, the , } \\
\text { degasification task, and the } \\
\text { installation of the beam support } \\
\text { brackets. }\end{array}$ \\
\hline$\cdot$ & . & & $\begin{array}{l}\text { MSHA/UMW - Agree with projection; } \\
\text { this injury level is typical of } \\
\text { this hazard. }\end{array}$ \\
\hline $\begin{array}{l}\text { Operator or helper slip } \\
\text { while barring down loose } \\
\text { rock. }\end{array}$ & $0 / 1 / 0$ & $0 / 1 / 0$ & $\begin{array}{l}\text { B of M/MSHA/UMW - Agree with } \\
\text { projection; the protection } \\
\text { provided by the canopy helps } \\
\text { prevent most debris from falling } \\
\text { on the work platforms, and the } \\
\text { protection does not require } \\
\text { workers to have to move quickly } \\
\text { out of the way of dislodged, } \\
\text { falling rock. }\end{array}$ \\
\hline $\begin{array}{l}\text { Slip and fall while } \\
\text { operating miner. }\end{array}$ & $\begin{array}{l}\text { Much less } \\
0 / 11 / 5\end{array}$ & $0 / 0 / 0$ & $\begin{array}{l}\text { B of M/MSHA/UMW - Agree with } \\
\text { projection; remote operation } \\
\text { removes interaction with the miner. }\end{array}$ \\
\hline $\begin{array}{l}\text { Slip or fall while } \\
\text { moving or operating other } \\
\text { machinery }\end{array}$ & $0 / 334 / 121$ & $0 / 284-334 / 103-121$ & $\begin{array}{l}\text { B of M/UMW - Agree with } \\
\text { projection; there is alot of } \\
\text { congestion around the hoists; } \\
\text { workers can slip and cause other } \\
\text { workers to fall; the shotcrete and } \\
\text { hoist hazards aggravate the } \\
\text { expusure. }\end{array}$ \\
\hline & & & $\begin{array}{l}\text { MSHA - Better lighting might } \\
\text { offset the exposure slightly; } \\
\text { otherwise, agree with projection. }\end{array}$ \\
\hline $\begin{array}{l}\text { Slip and fall while doing } \\
\text { cleanup. }\end{array}$ & $0 / 120 / 32$ & $0 / 60-120 / 16-32$ & $\begin{array}{l}\text { B of M/MSHA/UMW - The Improved } \\
\text { lighting. would improve visibility } \\
\text { of obstacles; but exposure is } \\
\text { still greater so one would expect } \\
\text { more injuries than the historical } \\
\text { level. Leaking hydraulic fluid } \\
\text { and standing water f'rom the tace } \\
\text { spray and shotcrete aggravates } \\
\text { this hazard. }\end{array}$ \\
\hline
\end{tabular}


Accident Class: Slip and Fall (Continuation 1)

\begin{tabular}{|c|c|c|c|}
\hline Hazard/Activity & $\begin{array}{l}\text { Initial Injury } \\
\text { Projection } \\
\text { F/DI/NDI }\end{array}$ & $\begin{array}{l}\text { Adjustment } \\
\text { by Experts } \\
\text { F/DI/NDI }\end{array}$ & Reason . '. . \\
\hline $\begin{array}{l}\text { Slip and fali off } \\
\text { machinery while doing } \\
\text { maintenance: }\end{array}$ & $.0 / 72 / 24$ & $0 / 61-72 / 20-24$ & $\begin{array}{l}\text { B of M/UMW - Agree with pro- } \\
\text { jection; the size of the tunnel } \\
\text { borer, degas drill, and hoists } \\
\text { aggravate falls from an elevation } \\
\text { and offsets the improved lighting. } \\
\text { MSHA - the improved lighting might } \\
\text { reduce exposure slightly; } \\
\text { otherwise, agree with projection. }\end{array}$ \\
\hline $\begin{array}{l}\text { Slip and fall while } \\
\text { handling awkward } \\
\text { supplies and handtools } \\
\text { to install components. }\end{array}$ & $0 / 679 / 144$ & $0 / 679 / 144$ & $\begin{array}{l}\text { B of M/MSHA/UMW - Agree with pro- } \\
\text { jection; the hoist and shot- } \\
\text { creting activities are very labor } \\
\text { intensive and cause alot of } \\
\text { congestion; workers can slip and } \\
\text { strike other workers. The hoist } \\
\text { and shotcrete hazards also } \\
\text { aggravate slips and falls. The } \\
\text { curved rib also contributes to } \\
\text { this hazard. }\end{array}$ \\
\hline $\begin{array}{l}\text { Slip and fall while } \\
\text { cable reeling. }\end{array}$ & $0 / 0 / 0$ & $0 / 4 / 1$ & $\begin{array}{l}\text { B of M/MSHA/UMW - There is a } \\
\text { slight chance of workers slipping } \\
\text { on the curved rib while hanging } \\
\text { the power cable. }\end{array}$ \\
\hline $\begin{array}{l}\text { Slip and fall while } \\
\text { laying or repairing } \\
\text { track. }\end{array}$ & $0 / 12 / 1$ & $0 / 8 / 1$ & $\begin{array}{l}\text { B of M/MSHA/UMW - The prefab- } \\
\text { cated track and use of the hoist } \\
\text { removes some of the exposure while } \\
\text { laying track, but does not of fset } \\
\text { exposure while repairing track. }\end{array}$ \\
\hline $\begin{array}{l}\text { Slip and fall while } \\
\text { operating or articulating } \\
\text { conveyor. }\end{array}$ & $\begin{array}{l}\text { Much less } \\
\text { than } \\
0 / 22 / 6\end{array}$ & $0 / 0 / 0$ & $\begin{array}{l}\text { B of M/MSHA/UMW - Removal of the } \\
\text { conveyor from the working area } \\
\text { offsets this hazard. }\end{array}$ \\
\hline
\end{tabular}




\section{Accident Class: Slip and Fall (Continuation 2)}

\begin{tabular}{|c|c|c|c|}
\hline Hazard/Activity & $\begin{array}{l}\text { Initial Injury } \\
\text { Projection } \\
\text { F/DI/NDI }\end{array}$ & $\begin{array}{l}\text { Adjustment } \\
\text { by Experts } \\
\text { F/DI/NDI }\end{array}$ & Reason \\
\hline $\begin{array}{l}\text { Slip and fall while } \\
\text { operating locomotive, } \\
\text { rerailing equipment, } \\
\text { getting on or off } \\
\text { equipment, riding } \\
\text { equipment, or coupling } \\
\text { cars. }\end{array}$ & $0 / 118 / 49$ & $0 / 94-118 / 39-49$ & $\begin{array}{l}\text { B of M/UMW - Agree with projec- } \\
\text { tion; workers often do not wait } \\
\text { for equipment to stop before } \\
\text { getting on or off. } \\
\text { MSHA - Though there could still } \\
\text { be bumps in the floor due to } \\
\text { floor heave (which can contribute } \\
\text { to derailments), the circular } \\
\text { entry, shotcrete lining and } \\
\text { improved lighting might } \\
\text { respectively reduce the amount of } \\
\text { debris in the path of the cars and } \\
\text { workers, and give workers better } \\
\text { visibility of obstacles when } \\
\text { getting off machinery. }\end{array}$ \\
\hline $\begin{array}{l}\text { Slip and fall setting } \\
\text { or removing props. }\end{array}$ & $0 / 2 / 0$ & $0 / 2 / 2$ & $\begin{array}{l}\text { B of M/MSHA/UMW - Basically } \\
\text { agree with projection; slight } \\
\text { exposure exists if props are } \\
\text { necessary during face maintenance. }\end{array}$ \\
\hline $\begin{array}{l}\text { Slip and fall while } \\
\text { setting brattice. }\end{array}$ & $0 / 0 / 0$ & $0 / 0 / 0$ & $\begin{array}{l}\text { B of M/MSHA/UMW - Agree with pro- } \\
\text { jection; task removed. }\end{array}$ \\
\hline $\begin{array}{l}\text { Slip and fall while } \\
\text { supervising or escaping } \\
\text { a hazard. }\end{array}$ & $0 / 278 / 89$ & $0 / 209-278 / 67-89$ & $\begin{array}{l}\text { B of M/MSHA - The equipment } \\
\text { layout and improved lighting } \\
\text { offer more room and better } \\
\text { visibility of operations, and } \\
\text { therefore offset exposure slightly. } \\
\text { UMW - Agree with projection; } \\
\text { supervisors often are absorbed in } \\
\text { task and do not observe presence } \\
\text { of hazard. }\end{array}$ \\
\hline
\end{tabular}




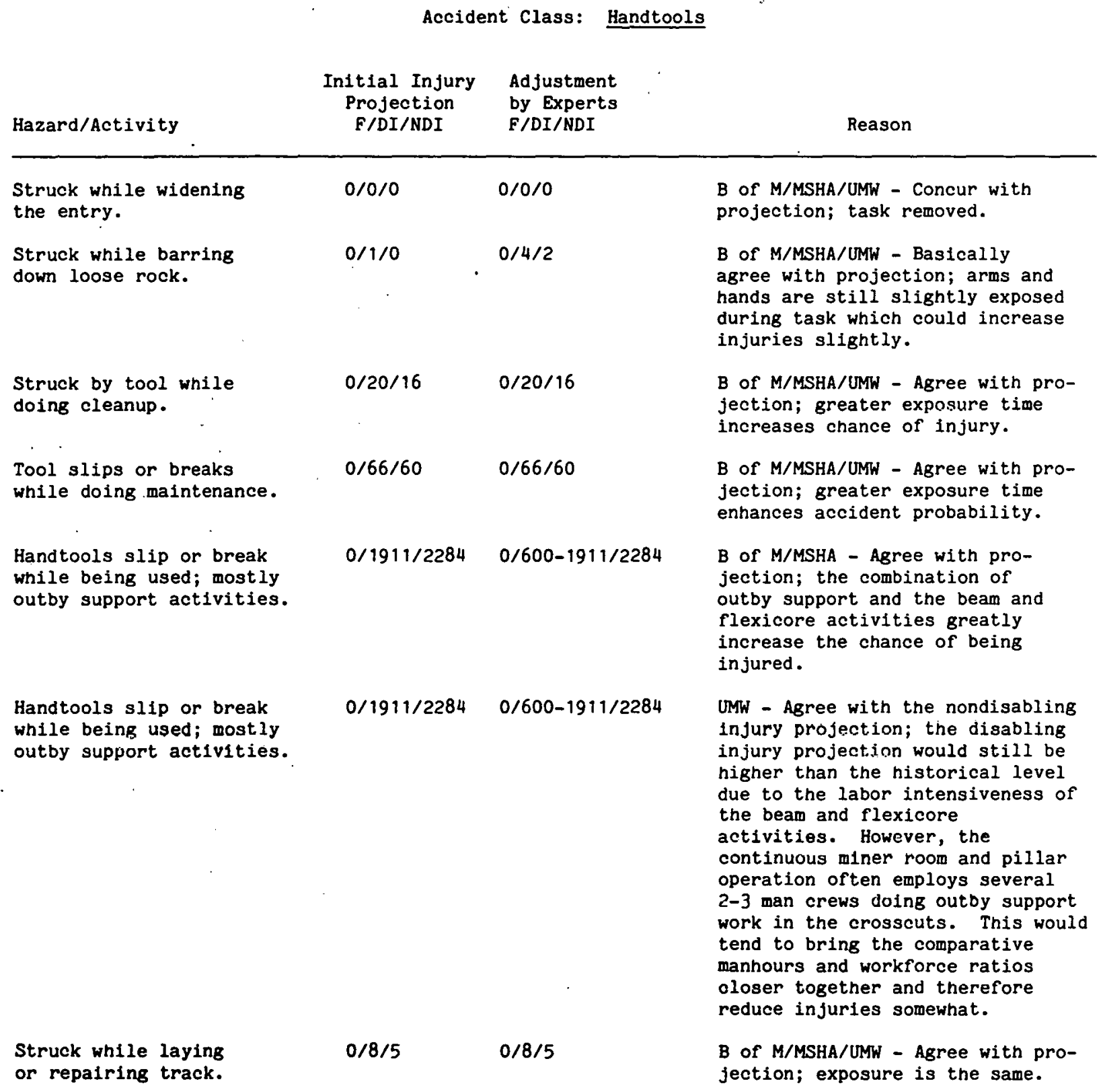




\begin{tabular}{|c|c|c|c|}
\hline Hazard/Activity & $\begin{array}{l}\text { Accident Class: } \\
\text { Initial Injury } \\
\text { Projection } \\
\text { F/DI/NDI }\end{array}$ & $\begin{array}{l}\text { Handtools } \\
\text { Adjustment } \\
\text { by Experts } \\
\text { F/DI/NDI }\end{array}$ & lation 1) \\
\hline $\begin{array}{l}\text { Tool slips while } \\
\text { handling supplies. }\end{array}$ & $0 / 68 / 42$ & $0 / 68 / 42$ & $\begin{array}{l}\text { B of M/MSHA/UMW - Concur with } \\
\text { projection; tunnel borer system } \\
\text { would probably use carrying } \\
\text { slings, tongs, clamps, etc. to a } \\
\text { greater extent than the continuous } \\
\text { miner system. The larger } \\
\text { workforce and manhours also } \\
\text { increase exposure. }\end{array}$ \\
\hline $\begin{array}{l}\text { Struck while coupling } \\
\text { cars or rerailing cars. }\end{array}$ & $0 / 17 / 8$ & $0 / 17 / 8$ & $\begin{array}{l}\text { B of M/MSHA/UMW - Agree with pro- } \\
\text { jection; exposure is the same. }\end{array}$ \\
\hline $\begin{array}{l}\text { Struck while tightening } \\
\text { drills. }\end{array}$ & $0 / 35 / 46$ & $0 / 35 / 46$ & $\begin{array}{l}\text { B of M/MSHA/UMW - Concur with } \\
\text { projection; more drill activity } \\
\text { exists with the tunnel borer } \\
\text { system. }\end{array}$ \\
\hline $\begin{array}{l}\text { Tool slips or breaks } \\
\text { while setting props or } \\
\text { timber. }\end{array}$ & $0 / 3 / 2$ & $0 / 3 / 2$ & $\begin{array}{l}\text { B of M/MSHA/UMW - Agree with pro- } \\
\text { jection; task is reduced } \\
\text { considerably, thereby reducing } \\
\text { exposure. }\end{array}$ \\
\hline $\begin{array}{l}\text { Struck while setting } \\
\text { brattice. }\end{array}$ & $0 / 0 / 0$ & $0 / 0 / 0$ & $\begin{array}{l}\text { B of M/MSHA/UMW - Agree with pro- } \\
\text { jection; task removed. }\end{array}$ \\
\hline $\begin{array}{l}\text { Tool slips while } \\
\text { adjusting conveyor. }\end{array}$ & $0 / 0 / 1$ & $0 / 0 / 1$ & $\begin{array}{l}\text { B of M/MSHA/UMW - Concur with } \\
\text { projection; exposure is the same. }\end{array}$ \\
\hline $\begin{array}{l}\text { Supervisor struck } \\
\text { by tool }\end{array}$ & $0 / 4 / 4$ & $0 / 4 / 4$ & $\begin{array}{l}\text { B of M/MSHA/UMW - Agree with pro- } \\
\text { jection; supervisors usually work } \\
\text { closely with workers during } \\
\text { handtool operations (such as } \\
\text { maintenance). }\end{array}$ \\
\hline
\end{tabular}




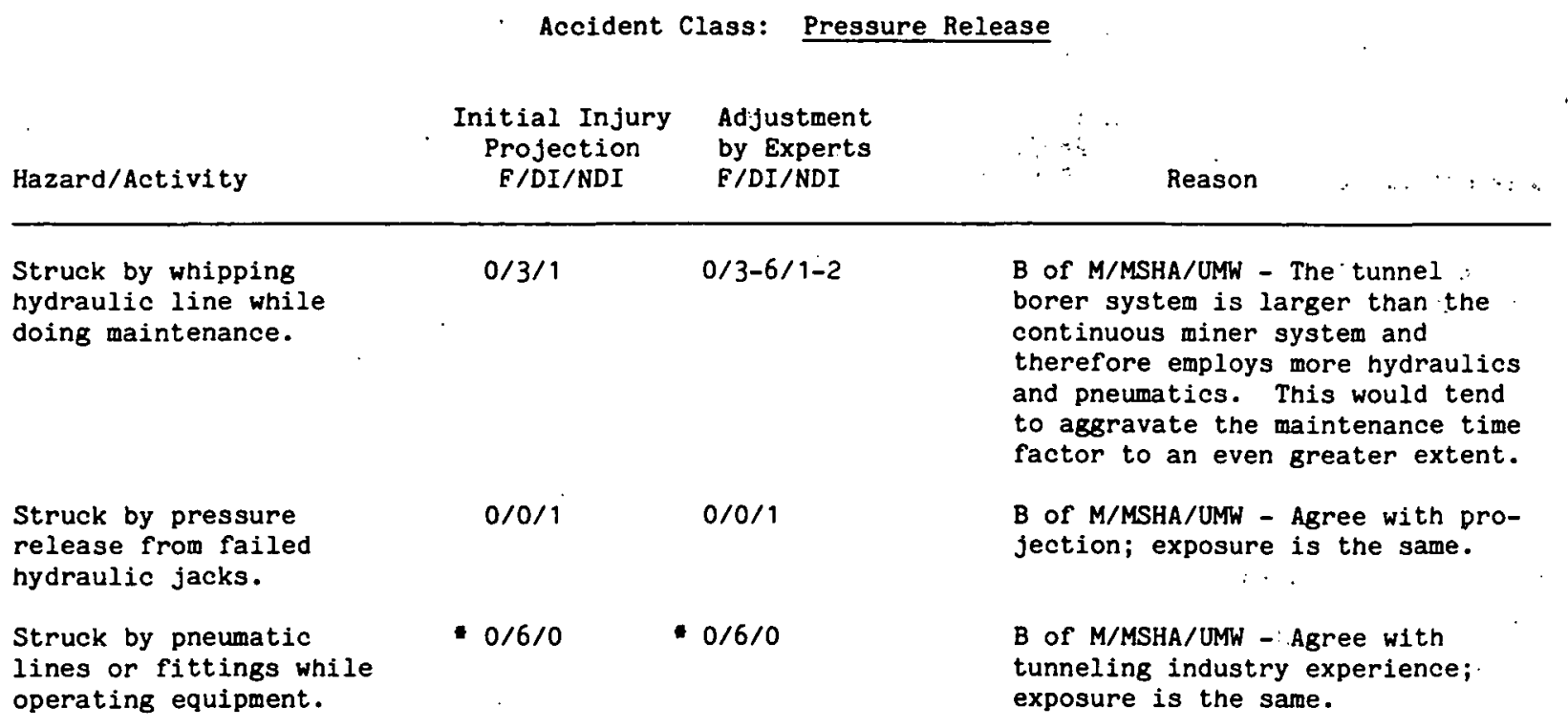

- Injuries per million manhours. 